University of California, Hastings College of the Law UC Hastings Scholarship Repository

Faculty Scholarship

1986

\title{
The Revival of Fact Pleading Under the Federal Rules of Civil Procedure
}

Richard L. Marcus

UC Hastings College of the Law, marcusr@uchastings.edu

Follow this and additional works at: http://repository.uchastings.edu/faculty_scholarship Part of the Civil Procedure Commons

\section{Recommended Citation}

Richard L. Marcus, The Revival of Fact Pleading Under the Federal Rules of Civil Procedure, 86 Colum. L. Rev. 433 (1986). Available at: http://repository.uchastings.edu/faculty_scholarship/468

This Article is brought to you for free and open access by UC Hastings Scholarship Repository. It has been accepted for inclusion in Faculty Scholarship by an authorized administrator of UC Hastings Scholarship Repository. For more information, please contact marcusc@uchastings.edu. 


\section{Faculty Publications \\ UC Hastings College of the Law Library}

Author: $\quad$ Richard L. Marcus

Source: $\quad$ Columbia Law Review

Citation: $\quad 86$ Colum. L. Rev. 433 (1986).

Title: $\quad$ The Revival of Fact Pleading Under the Federal Rules of Civil Procedure

Originally published in COLUMBIA LAW REVIEW. This article is reprinted with permission from COLUMBIA LAW REVIEW and Columbia University School of Law. 


\section{COLUMBIA LAW REVIEW}

VOL. 86

APRIL 1986

NO. 3

\section{THE REVIVAL OF FACT PLEADING UNDER THE FEDERAL RULES OF GIVIL PROGEDURE}

\section{Richard L. Marcus*}

Unfortunately by a kind of Gresham's Law, the bad, or harsh, procedural decisions drive out the good, so that in time a rule becomes entirely obscured by its interpretive barnacles.

Charles E. Clark ${ }^{1}$

As Dean of Yale Law School and reporter of the committee that drafted the Federal Rules of Civil Procedure, Charles Clark ${ }^{2}$ was the principal architect of the Rules and leading proponent of the liberal ethos that underlies them. His pessimism about procedural reform therefore deserves attention. This Article examines the fate of the centerpiece of Clark's new system-simplified pleading under Rule 8(a)(2), which requires only "a short and plain statement of the claim showing that the pleader is entitled to relief."3 This Rule was designed to escape the complexities of fact pleading under the codes, which had generated great confusion about how to allege the required "ultimate facts" while avoiding forbidden "conclusions" and "mere evidence." There were pockets of resistance against the new pleading rules in the years after $1938,{ }^{4}$ but in 1957 the Supreme Court threw its weight decisively behind the new liberal ethos in Conley $v$. Gibson: 5 "[A] complaint should not be dismissed for failure to state a claim unless it appears

* Professor of Law, University of Illinois. B.A. 1969, Pomona; J.D. 1972, University of California, Berkeley. I received numerous helpful suggestions from the participants in an Illinois Faculty Workshop that discussed some of these ideas. In addition, I am indebted to United States District Judge Milton Shadur (N.D. Ill.) and Jan Vetter, who reviewed earlier drafts of this Article and made numerous helpful comments, and to Ed Wilhoite who provided valuable research assistance. All errors that remain are mine alone.

1. Clark, Special Problems in Drafting and Interpreting Procedural Codes and Rules, 3 Vand. L. Rev. 493, 498 (1950).

2. Charles Clark graduated from Yale Law School in 1913, and began to teach there in 1919. From 1929 to 1939 he was Dean. In 1939, he was appointed a judge of the Second Circuit, of which he served as Chief Judge from 1954 to 1959 . From 1935 to 1956 he served as Reporter of the Supreme Court's Committee on the Rules of Civil Procedure, which drafted the rules. See 4 Who Was Who in America 174 (1968).

3. Fed. R. Civ. P. 8(a)(2); see also 5 C. Wright \& A. Miller, Federal Practice \& Procedure $\S 1202$, at 59 (1969) ("Rule 8 is the keystone of the system of pleading embodied in the federal rnles."); Smith, Judge Charles E. Clark and The Federal Rules of Civil Procedure, 85 Yale L.J. 914, 917-I8 (1976) (general pleading was one of Clark's thrce basic goals for new procedural rules).

4. Sce infra notes $69-71$ and accompanying text.

5. 355 U.S. 41 (1957). 
beyond doubt that the plaintiff can prove no set of facts in support of his claim that would entitle him to relief." 6 Clark could hardly have put it more forcefully himself.

Although Conley $v$. Gibson put the Supreme Court on record as clearly favoring the liberal view, the actual application of its admonition in subsequent cases was more problematic. Taken literally, it might have precluded dismissal in any case where the plaintiff invoked a valid legal theory. How can a court ever be certain that a plaintiff will prove no set of facts entitling him to relief? The case itself provided little help. Plaintiffs were black union members who accused their union of racial discrimination. Defendants argued that the complaint failed to state a claim because it lacked particulars about their allegedly discriminatory activities. The lower courts did not accept that argument, ${ }^{7}$ and the Supreme Court rejected it with the broad statement quoted above. But the complaint did contain particulars, and the case could have been decided without such sweeping language. ${ }^{8}$ The Court's broad language was intended for other cases, not this one. Pleadings were intended only to give general notice, it seemed, and pleading practice was to shrivel and die.

One seeming impact of Conley $v$. Gibson was that commentators lost interest in pleading. For years before and after the adoption of the Federal Rules in 1938, pleading had been the subject of intense academic discussion. ${ }^{9}$ After the decision, this discussion stopped abruptly. Perhaps that was because some viewed the battle about detailed pleadings as irretrievably over, ${ }^{10}$ or because they understood that Conley authorized a "fishing expedition" to determine whether plaintiff actually had a claim. ${ }^{11}$ Whatever the reason, for more than twenty years after Conley, there was virtually no academic recognition that pleading practice had not vanished; defendants continued to make motions to dismiss and courts continued to grant them. Only recently have commentators begun to acknowledge this reality. ${ }^{12}$

6. Id. at $45-46$ (citations omitted).

7. The lower courts had dismissed on the ground that the claim was subject to the exclusive jurisdiction of the Railroad Adjustment Board. The Supreme Court rejected that argument. See id. at $43-44$.

8. Plaintiffs alleged, for example, that the defendant union maintained two separate locals, one for whites and the other for blacks, providing inferior representation to the black local, see Complaint II VI, VII, Transcript of Record at 8-11, Conley, and that in May, 1954, with the connivance of the union, the railroad had fired 45 blacks and replaced them with whites, see Complaint II VIII, X, Transcript of Record at 11-13.

9. For a collection of such authorities, see Weinstein \& Distler, Drafting Pleading Rules, 57 Colum. L. Rev. 518, 524-25 (1957).

10. See, e.g., Friedenthal, A Divided Supreme Court Adopts Discovery Amendments to the Federal Rules of Civil Procedure, 69 Calif. L. Rev. 806, 816 (1981) ("Once it became clear that the battle for a return to the code formulation was irretrievably lost, other devices were utilized to raise the same issue in different contexts.").

11. F. James \& G. Hazard, Civil Procedure $\$ 3.11$, at 153-54 (3d ed. 1985).

I2. This commentary tends to focus on narrow problems rather than the more gen- 
Not only has pleading practice survived, but fact pleading, the bête noir of the codes, seems to be enjoying a revival in a number of areas in which courts refuse to accept "conclusory" allegations as sufficient under the Federal Rules. Consider, for example, Heart Disease Research Foundation v. General Motors Corp., ${ }^{13}$ which the Guinness Book of World Records listed as the suit with the largest damage claim in the history of litigation, $\$ 375$ trillion. ${ }^{14}$ Plaintiff sued on behalf of a class of 125 million American urban dwellers alleging that the defendant Big Four automakers had conspired in violation of the Sherman Antitrust Act to restrain the development of automobile air pollution mechanisms, thereby polluting the atmosphere of North America. The Second Circuit affirmed the trial court's dismissal for failure to state a claim ${ }^{15}$ because "it was well within the district court's discretion to dismiss the claim since no facts are alleged supporting an antitrust conspiracy. Although the Federal Rules permit statement of ultimate facts, a bare bones statement of conspiracy or of injury under the antitrust laws without any supporting facts permits dismissal."16 This attitude appears worlds away from the approach articulated in Conley. The result becomes more remarkable when one considers that the United States had also sued the Big Four alleging the same conspiracy, and ultimately obtained a consent decree in that litigation for "essentially all" the relief it had sought. ${ }^{17}$ The dismissal upheld by the Second Circuit was certainly correct on other grounds, ${ }^{18}$ but it illustrates that Conley is not

eral question of the role of pleadings in the modern litigation system. See, e.g., Roberts, Fact Pleading, Notice Pleading, and Standing, 65 Cornell L. Rev. 390, 399-400, 415 (1980); Saveri \& Saveri, Pleading Fraudulent Concealment in an Antitrust Price Fixing Case: Rule 9(b) v. Rule 8, 17 U.S.F.L. Rev. 631, 639-40 (1983); Sovern, Reconsidering Federal Civil Rule 9(b): Do We Need Particularized Pleading Requirements in Fraud Cases?, 104 F.R.D. 143, 150 (1985); Wingate, A Special Pleading Rule for Civil Rights Complaints: A Step Forward or a Step Back?, 49 Mo. L. Rev. 677, 680-83 (1984); Note, Pleading Sccurties Fraud Claims With Particularity Under Rule 9(b), 97 Harv. L. Rev. 1432 (1984).

13. 463 F.2d 98 (2d Cir. 1972).

14. N. McWhirter \& R. McWhirter, Guinness Book of World Records 387 (12th ed. 1973). The case has since been eclipsed by more ambitious litigation. See Windsor v. Pan American Airways, 744 F.2d 1187 (5th Cir. 1984) (suit for $\$ 400$ trillion).

15. The district court had relied in the alternative on Fed. R. Civ. P. 11. See Heart Disease Research Found. v. General Motors Corp., 15 Fed. R. Serv. 2d (Callaghan) 1517, 1519 (S.D.N.Y. 1972). The Second Circuit chose not to rely on that ground. See 463 F.2d at 100 .

16. $463 \mathrm{~F} .2 \mathrm{~d}$ at 100 .

17. This litigation was filed, along with the massive antitrust suit against I.B.M., in the last days of the Johnson Administration. See R. Harris, Justice I28 (1970). The government suit charged a conspiracy beginning at least as early as 1953 to retard competition in the development of air pollution control equipment. After negotiations, the government and the automakers agreed to a consent judgment in October, 1969, which "granted essentially all of the relief which the government had sought." United States v. Motor Vehicle Mfrs. Ass'n, 643 F.2d 644, 645 (9th Cir. I981).

18. As a nonprofit foundation, the plaintiff had no standing to sue for damages under the antitrust laws. Cf. In re Multidistrict Vehicle Air Pollution, 481 F.2d 122 (9th 
taken literally. This case, moreover, is not an anomaly. Although they rarely acknowledge the shift, ${ }^{19}$ federal courts are insisting on detailed factual allegations more and more often, particularly in securities fraud and civil rights cases. ${ }^{20}$

Does the revival of fact pleading show that Clark was right to expect the courts to undermine his liberal reforms with restrictive barnacles? Using this question as a starting point for an analysis of the proper role of pleadings under the Federal Rules, this Article concludes that reality is more complicated. The new fact pleading is an effort to cope with the pressures of the litigation boom, itself caused in part by the innovations of the Federal Rules. Contrary to the conventional wisdom that the sole purpose of pleadings is to give notice, this Article suggests that their role should be to enable courts to decide cases on their merits. The important question then is how pleading rules can be used to accomplish that purpose. Unfortunately, operating in the shadow of Conley $v$. Gibson and caught up in the vocabulary of notice pleading, the courts have not given that question much attention.

This Article finds that the answer is to look for cases in which the plaintiff's legal conclusions can be profitably evaluated. It identifies two broad categories of such cases-those in which more specificity is likely to disclose a fatal defect in a plaintiff's case, and those in which sufficient detail will enable the court to make a reliable determination that the defendant did not violate the plaintiff's rights. Used in this fashion, pleading practice is an important tool, but not a panacea. In other kinds of cases, whether purportedly justified as providing "notice" or otherwise, pleading motions are largely a waste of time.

The new fact pleading does not stop with these two kinds of cases, however. Courts now regularly use it, as in Heart Disease Research Foundation, to probe and reject plaintiff's factual conclusions. Although this practice is understandable in view of the breadth of modern discovery and the limits on summary judgment, it does not provide a reliable method for determining whether a defendant has violated the plaintiff's rights because it requires the plaintiff to marshall evidence before conducting discovery. Neither can it be justified as a special way of handling certain "suspicious" claims or as a step toward discretionary dismissals. Instead, the preferable route for probing plaintiff's factual conclusions should be to rely on more flexible use of summary judgment. Under this approach, the principal focus would often be on the

Cir.) (holding that state governments and crop farmers lacked standing to seek damages in litigation over same conspiracy), cert. denied, 414 U.S. 1045 (1973).

19. See Roberts, supra note 12, at 420 ("What is most noteworthy about this slow erosion of federal notice pleading . . . is the utter silence in which the process is taking place."). For a review of the new fact pleading cases, see infra notes 84-104 and acconpanying text.

20. See infra notes 84-101 and accompanying text. 
amount of discovery to be allowed a plaintiff under Rule $56(\mathrm{f})$ before ruling on summary judgment, thereby controlling the risk of abuse of discovery. Such flexible use of summary judgment would be particularly effective if done in conjuction with more active case management by judges. Combined with selective cost-shifting in cases of proven litigation abuse, this evidentiary scrutiny would provide a better system for pretrial disposition.

\section{The Evolution and Corruption of Simplified Pleading}

\section{A. The Sins of the Past}

In pleading, they studiously avoid entering into the Merits of the Cause; but are loud, violent and tedious in dwelling upon Circumstances which are not to the Purpose.

Jonathan Swift ${ }^{21}$

Common law pleading, which was originally oral, evolved over centuries into an increasingly detailed written exercise. During the same period, the forms of action were developing, and their limitations reinforced pleading difficulties. In order to prevail, the common law plaintiff had to choose the correct form of action. He and his lawyer then embarked on an exchange of pleadings with the defendant that was designed ultimately to produce a single issue for resolution by a judge or trial by a jury, ${ }^{22}$ with trial itself as something of an afterthought to the pleading process. ${ }^{23}$

Whatever the wisdom of the common law approach as an abstract system, it proved extremely susceptible to Gresham's Law. Over time, it became necessary to use highly stylized verbal formulations to present even simple grievances. These expressions-known as "color"often had little relation to the underlying facts of the particular case. ${ }^{24}$ They certainly told the defendant little or nothing about the plaintiff's claims, and the defendant would remain in the dark until trial because discovery was limited or nonexistent. Nevertheless, the defendant could take comfort in the prospect that the plaintiff could ultimately lose because his lawyer bungled the pleading war. As pleading practice prospered, decisions on the merits became increasingly infrequent. ${ }^{25}$ 1726).

21. J. Swift, Gulliver's Travels 352-53 (H. Williams ed. 1926) (1st ed. London

22. For a description of this ritual, see A. Harding, The Law Courts of Medieval England 78-79 (1973).

23. R. Palmer, The County Courts of Medieval England 90 (1982); see also A. Harding, supra note 22, at 78 ("Cases were often decided by the pleading-contest rather than by jury or the other methods of trial.") (citation omitted).

24. On the growth of legal fictions, see Sutherland, Legal Reasoning in the Fourteenth Century: The Invention of "Color" in Pleading, in On the Laws and Customs of England, Essays in Honor of Samuel Thorne 182 (M. Arnold, T. Green, S. Scully \& S. White eds. I98I).

25. See F. James \& G. Hazard, supra note I1, § 3.2, at 132. 
Popular dissatisfaction with this situation in England led, in the late nineteenth century, to abandonment of the forms of action and simplification of pleading. ${ }^{26} \mathrm{~A}$ movement for similar reforms in this country was spearheaded by David Dudley Field, the drafter of the New York code adopted in 1848. While one may question whether American judges were really so formalistic as the reformers suggested, ${ }^{27}$ it was clear that the Field Code reforms were intended to eliminate decisions based on technicalities. In place of stylized verbiage, the Code directed that the complaint contain "[a] statement of the facts constituting the cause of action, in ordinary and concise language, without repetition, and in such a manner as to enable a person of common understanding to know what is intended." 28

The high hopes for the Field Code were not realized. In part, one may attribute this failure to judicial sabotage. ${ }^{29}$ No doubt the Code's fate was what Clark had in mind when he spoke of Gresham's Law. But there were real problems with the codifier's reformulation of pleading rules in that they invited unresolvable disputes about whether certain assertions were allegations of ultimate fact (proper), mere evidence (improper), or conclusions (improper). ${ }^{30}$ In particular, there was great difficulty distinguishing ultimate facts from conclusions since so many concepts, like agreement, ownership and execution, contain a mixture of historical fact and legal conclusion. Pleading decisions caused increasing difficulty for even the most common claims. For example, the detail needed to allege negligence was regularly recalibrated. ${ }^{31}$ Such fencing among lawyers led to stagnation that interfered with resolution of disputes on their merits.

26. See generally 15. W. Holdsworth, A History of English Law 128-32 (A. Goodhard \& H. Hanbury ed. 1965) (describing the Judicature Act of 1873, which simplified pleading in England).

27. Indeed, the Field Code itself may be viewed as an example of 19 th century formalism. See M. Horwitz, The Transformation of American Law 265-66 (1977).

28. An Act to simplify and abridge the Practice, Pleadings and Proceedings of the Courts of this State, ch. 379, $\$ 120(2), 1848$ N.Y. Laws 521.

29. See McArthur v. Moffet, 143 Wis. 564, 567, 128 N.W. 445, 446 (1910) (reforring to "[t]he cold, not to say inhuman, treatment which the infant Code received from the New York judges").

30. See Cook, Statements of Fact in Pleading Under the Codes, 21 Colum. L. Rev. 416,417 (1921), for an argument that these distinctions are ultimately meaningless. But cf. McCaskill, Actions and Causes of Action, 34 Yale L.J. 614, 620 (1925) (arguing that cause of action concept must be retained because pleadings will otherwise be "half baked and undigestible").

31. See, e.g., Gillispie v. Goodyear Serv. Stores, 258 N.C. $487,490,128$ S.E.2d 762 , 765 (1963) (" "N]egligence is not a fact in itself, but is the legal result of cortain facts." ") (quoting Shives v. Sample, 238 N.C. 724, 726, 79 S.E.2d 193, 195 (1953)); cf. C. Clark, Handbook of the Law of Code Pleading $\$ 47$, at 300-03 (2d ed. 1947) (noting that requirements for pleading negligence under code pleading werc actually morc dcmanding than under common law). 


\section{B. The Federal Rules: The Liberal Ethos Triumphant}

Ancestor worship in the form of ritualistic pleadings has no more disciples. The time when the slip of a sergeant's quill pen could spell death for a plaintiff's cause of action is past. Under the Federal Rules of Civil Procedure, a complaint is not an anagrammatic exercise in which the pleader must find just exactly the prescribed combination of words and phrases.

$$
\text { Judge John Minor Wisdom }{ }^{32}
$$

Sobered by the fate of the Field Code, Dean Clark and the other drafters of the Federal Rules set out to devise a procedural system that would install what may be labelled the "liberal ethos," in which the preferred disposition is on the merits, by jury trial, after full disclosure through discovery. ${ }^{33}$ At first, Clark favored eliminating pleading motions altogether. ${ }^{34}$ Ultimately other voices held sway, but Rule 8(a)(2) was drafted carefully to avoid use of the charged phrases "fact," "conclusion," and "cause of action." To make the point clearer, the drafters prepared a series of form complaints that were by definition sufficient to satisfy the new standard. ${ }^{35}$ These forms were startlingly brief. For example, Form 9 preempted decades of pleading litigation by declaring sufficient the allegation that "defendant negligently drove a motor vehicle against plaintiff." 36 No longer would the objection that negligence was a legal conclusion hold sway.

Clark did not expect that most complaints would be as abbreviated as the form complaints, and he hoped that most pleaders would continue to do their pleading carefully. ${ }^{37}$ Nonetheless, he had little pa-

32. Thompson v. Allstate Ins. Co., 476 F.2d 746, 749 (5th Cir. 1973).

33. See Clark, The Handmaid of Justice, 23 Wash. U.L.Q. 297, 3I8-19 (I938) (denouncing attempts to resolve cases on pleadings and asserting that "in the case of a real dispute, there is no substitute anywhere for a trial"); see also infra text accompanying note 343 .

This is not to say that all the framers of the rules were enthusiastic about jury trial. To the contrary, some have characterized the attitude of the rules' framers as mistrusting juries and preferring resolutions by judges (presumably on summary judgment). See 2I C. Wright \& K. Graham, Federal Practice \& Procedure, § 5025, at I46-51 (1977) (describing "Progressive Procedural Paradigm"). But their hopes for summary judgment were not vindicated by subsequent events, which made summary judgment difficult to obtain. See infra notes 297-303 and accompanying text; cf. Clark, supra, at 318 (summary judgment "is adapted only for rather simple issues where the facts are on the surface"). Instead, under the influence of Conley $v$. Gibson, the customary decision-making method became jury trial, as was desired by Conley's author, Justice Black. See Kaufman, The Federal Civil Rules and the Pursuit of Justice, in Hugo Black and the Supreme Court; A Symposium 221, 224-25 (S. Strickland ed. 1967) (Black was the nost vigorous champion of jury trial in Supreme Court history.).

34. Smith, supra note 3 , at 927-28.

35. Fed. R. Giv. P. 84 declares that "[t]he forms contained in the Appendix of Forms are sufficient under the rules and are intended to indicate the simplicity and brevity of statement which the rules contemplate."

36. Form 9, Appendix of Forms, Fed. R. Civ. P.

37. See C. Clark, supra note $31, \S 39$, at 245. 
tience with the use of a "mere formal motion" 38 to challenge the sufficiency of the pleadings because it "really decides nothing of substance."39 Clark's protégé, Professor Moore, emphasized in his treatise that pleadings need "do little more than indicate generally the type of litigation that is involved."40 Rather than dwell on pleading niceties, under the new system litigants were to use the expanded discovery mechanisms provided by the Federal Rules to get to the merits of the case. Armed with that information, they could in appropriate cases move for summary judgment, allowing the court to decide the merits. Normally, however, the proper method for resolving them was trial by jury. ${ }^{41}$

The liberality of the pleading requirements is reflected throughout the Federal Rules. Thus, amendment of pleadings is freely granted, even after trial, 42 and the court is admonished in any event to grant the parties whatever relief they are entitled to after trial, whether they have requested it or not. ${ }^{43}$ By the time Conley $v$. Gibson was decided, the stage seemed set for assuring litigants decisions on the merits.

\section{The Sins of the Present: The Catharsis of the Liberal Ethos}

The history of procedure is a series of attempts to solve the problems created by the preceding generation's procedural reforms.

\section{Professor Judith Resnik ${ }^{44}$}

Whatever their internal symmetry, the Federal Rules contributed to a number of developments that have dismayed a considerable portion of the federal judiciary. Much ink has already been spilled on the litigation "boom" and the crisis in the adversary system, ${ }^{45}$ but dramatic increases in litigation are hardly unprecedented. ${ }^{46}$ The reader none-

38. Dioguardi v. Durning, 139 F.2d 774, 775 (2d Cir. 1944); cf. Gottreich v. San Francisco lnv. Corp., 552 F.2d 866, 867 (9th Cir. 1977) ("We had thought that this kind of nit-picking had disappeared in $1938 \ldots$. ..).

39. Proceedings of the Institute at Washington, D.C. and of the Symposium at New York City 54 (1938). These proceedings were held to publicize the new federal rules.

40. 2A J. Moore \& J. Lucas, Moore's Federal Practice 18.03 , at 8-10 (2d ed. 1985) [hereinafter cited as Moore's Federal Practice]; see Hickman v. Taylor, 329 U.S. 495, 501 (1947) ("The new rules, however, restrict the pleadings to the task of general notice-giving .....").

41. See supra note 33 and accompanying text.

42. See Fed. R. Civ. P. 15(b) (amendment to be allowed unless the objecting party shows prejudice).

43. See Fed. R. Civ. P. 54(c).

44. Resnik, Tiers, 57 S. Cal. L. Rev. 837, 1030 (1984).

45. See, e.g., R. Marcus \& E. Sherman, Complex Litigation: Cases and Materials on Advanced Civil Procedure I-22 (1985).

46. One researcher has found the conditions of 1946 to 1980 in the federal courts similar to those in 1876, when civil cases were more important than criminal. See Clark, Adjudication to Administration: A Statistical Analysis of Federal District Courts in the Twentieth Century, 55 S. Cal. L. Rev. 65, 123 (1981); see also id. at 99-105 (noting 
theless intuits that the existing pressures on the federal judicial system arose, somewhat unexpectedly, within the last twenty years. Things were not actually so tranquil during the Federal Rules' first quarter century, however. Ten years after the Rules were adopted, concern about protracted litigation caused the Judicial Conference of the United States to appoint a committee headed by Judge E. Barrett Prettyman to examine the peculiar problems caused by such litigation. ${ }^{47}$ In 1955, Chief Justice Warren commissioned a special panel of federal judges to study the handling of complicated cases, ${ }^{48}$ a process leading ultimately to the promulgation of the Manual for Complex Litigation. So the pressures of managing litigation were sensed soon after the Federal Rules came into effect. Undeniably, however, these concerns did escalate with the rapid rise in federal court filings during the 1960s and 1970s.

Peering out from behind this mountain of litigation, federal judges also perceived a pro-plaintiff shift in the balance of power in litigation resulting largely from the breadth of discovery, which could impose very substantial costs on defendants. ${ }^{49}$ Moreover, at least some courts said that once the plaintiff had obtained information through discovery he could do anything he wanted with it; discovery could even become the principal objective of a lawsuit, rather than merely a device for helping resolve it. ${ }^{50}$ Other procedural innovations, particularly the 1966 amendment of Rule 23 on class actions, seemed to load the dice in

burst of growth in civil filings between 1900 and 1907). England experienced a litigation boom in the 16 th and 17 th centuries. See Brooks, Litigants and Attorneys in the King's Bench and Common Pleas, 1560-1640, in Legal Records and the Historian 41 (J. Baker ed. 1978). Nor is the duration and magnitude of the current "boom" undisputed. See Galanter, Reading the Landscape of Disputes: What We Know and Don't Know (And Think We Know) About Our Allegedly Contentious and Litigious Society, 31 UCLA L. Rev. 4, 9 (1983) (In 1960, there was concern about a decline in litigation.).

47. The committee's report, entitled Procedure in Anti-trust and Other Protracted Cases, appears at 13 F.R.D. 62 (1951). The report anticipates much of the debate that would develop over the following three decades. Consider the following: "Pleadings will not serve to particularize issues sufficiently in these cases, and motions for particulars will not serve that purpose. Such particularization must be achieved by informal conferences between judge and counsel well in advance of a possible trial date." Id. at 67. This approach was ultimately adopted by the 1983 amendments to the Federal Rules. See infra note 61 and accompanying text.

48. The panel's proposal, entitled Handbook of Recommended Procedures for the Trial of Protracted Cases, appears at 25 F.R.D. 351 (1960).

49. See, e.g., In re Commonwealth Oil/Tesoro Petroleum Corp. Sec. Litig., 467 F. Supp. 227, 250 (W.D. Tex. 1979) ("unchecked access to the in terrorem power of the federal discovery mechanism"). Such argnments echo the debate about pleading specificity during the 1950s. See infra notes 69-71 and accompanying text; New Dyckman Theatre Corp. v. Radio-Keith-Orpheum Corp., 16 F.R.D. 203, 206 (S.D.N.Y. 1954) (Vague pleading becomes "a springboard . . . into an almost bottomless sea" of discovery in an antitrust case.).

50. See Chicago Council of Lawyers v. Bauer, 522 F.2d 242, 258 (7th Cir. 1975), cert. denied, 427 U.S. 912 (1976); accord, In re Halkin, 598 F.2d 176, 187 (D.C. Cir. 1979). For a criticism of this view, see Marcus, Myth and Reality in Protective Order Litigation, 69 Coruell L. Rev. 1, 29-41 (1983). 
favor of plaintiffs by greatly increasing the stakes and actually impeding disposition on the merits. ${ }^{51}$ Together with pro-plaintiff substantive changes, ${ }^{52}$ themselves fueled by successful discovery forays, ${ }^{53}$ the Rules' procedural innovations appeared to some to leave defendants little meaningful opportunity to prove their innocence on the merits. ${ }^{54}$ The result of this synergy was a litigation industry 55 in which the value

51. Milton Handler, for example, charged that the amended Rule 23 "utilizes the threat of unmanageable and expensive litigation to compel settlement . . . it is a form of legalized blackmail." Handler, The Shift from Substantive to Procedural Innovations in Antitrust Suits-The Twenty-third Annual Antitrust Review, 71 Colum. L. Rev. I, 9 (1971). For a time, there was considerable reason to take this view. By relaxing requirements for rule 23(b)(3) class actions for damages, the 1966 amendments certainly increased the stakes of litigation, and an action arguably was a class action from the date it was filed. Meanwhile, Eisen v. Carlisle \& Jacquelin, 417 U.S. 156 (1974), could be read to forbid consideration of the merits until the court had decided whether to certify a class, a process that could take months or years. But cf. Berry, Ending Substance's Indenture to Procedure: The Imperative for Comprehensive Revision of the Class Damage Action, 80 Colum. L. Rev. 299, 314 (1980) ("Despite [Eisen,] there is pervasive sentiment [among judges and lawyers] favoring some sort of preliminary hearing on the merits."). It should be noted that strictures on precertification merits decisions have been relaxed. See, e.g., Wright v. Schock, 742 F.2d 541 (9th Cir. 1984) (upholding precertification grant of defendant's motion for summary judgment). But class certification is still thought to give plaintiffs a bargaining edge in settlement negotiations. See Note, Certifying Classes and Subclasses in Title V1l Suits, 99 Harv. L. Rev. 619, 626-27 (1986).

52. Examples abound. Bad faith tort claims caused a variety of contract and other commercial disputes to take on new aspects. See, e.g., W. Keeton, D. Dobbs, R. Keeton $\&$ D. Owen, Prosser and Keeton on the Law of Torts 11 (5th ed. 1984) (growth in punitive damages claims for bad faith by insurance companies) [hereinafter cited as Prosser \& Keeton]; Farber, Reassessing the Economic Efficiency of Compensatory Damages for Breach of Contract, 66 Va. L. Rev. 1443, 1468-77 (1980) (arguing for supercompensatory damages in certain situations); Galane, Proving Punitive Damages in Business Tort Litigation, 2 Litig., Spring 1976, at 24, 24 (listing eight business torts in which punitive damages are available). Both compensatory and punitive awards have skyrocketed. See Friedman, The Six Million Dollar Man: Litigation and Rights Consciousness in Modern America, 39 Md. L. Rev. 661, 664-65 (1980).

53. See Friedenthal, supra note 10 , at $818-19 \&$ n.59 (discovery serves to stimulate growth of substantive remedies).

54. See, e.g., infra notes 58-60, 134 and accompanying text. This view is not universal. To the contrary, empirical investigation suggests that the current preoccupation with the litigation "boom" may be an overreaction. See Galanter, supra note 46, at 6I-69. Nevertheless, courts have scen a number of suits that seemed to have no value except as vexation or recreation. Sec, e.g., Hailes v. Equitable Life Assurance Soc'y, 729 F.2d 1037, 1037 (5th Cir. 1984) (employment discrimination claim "the product of a project to obtain a lawsuit-not a secretarial position"); Beachboard v. United States, 727 F.2d 1092, 1095 (Fed. Cir. 1984) ("The unescapable conclusion is that Beachboard is engaged on this appeal in 'recreational' litigation, misusing precious and limited resources better spent on meritorious claims of his fellow citizens . . . ."); Norman v. Reagan, 95 F.R.D. 476, 477 (D. Or. 1982) ("lt is possible, of course, that this is not intended as a claim at all, but as a literary artifact.").

55. Cf. In re Fine Paper Antitrust Litig., 98 F.R.D. 48,72 (E.D. Pa. 1983) (quoting a letter from counsel for plaintiff class referring to "plaintiffs' antitrust industry"), rev'd in part, 75 I F.2d 562 (3d Cir. 1984). 
of litigation appeared only slightly connected to the merits of claims being asserted-a "gigantic slot machine" approach to litigation ${ }^{56}$ in which the status of being a defendant overshadowed the merits of the underlying dispute. ${ }^{57}$

The Supreme Court increasingly has voiced concern about abuse of the litigation process by plaintiffs with groundless claims. In 1975, for example, in Blue Chip Stamps v. Manor Drug Stores, 58 the Court restricted standing to sue for securities fraud because "the liberal discovery provisions of the Federal Rules of Civil Procedure" give plaintiff "an in terrorem increment of the settlement value,"59 so that "even a complaint which by objective standards may have very little chance of success at trial has a settlement value to the plaintiff out of any proportion to its prospect of success at trial so long as he may prevent the suit from being resolved against him by dismissal or summary judgment."60

The same concerns led to pressures to change the Federal Rules

56. Friedenthal, supra note 10 , at 818 (referring to "plaintiffs who sometimes treat the judicial system as if it were a gigantic slot machine").

57. Symptomatic of this trend is the suggestion that the settlement value of meritless litigation is protected by the Sherman Antitrust Act against "conspiracy" by the defendants not to settle. In Lemelson v. United States, 3 Ct. Cl. 161 (1983), aff'd in part, vacated in part, 752 F.2d 1538 (Fed. Cir. 1985), for example, plaintiff sued the United States and two third party defendants for violating plaintiff's patent. After settlement negotiations were unsuccessful, the infringement case went to trial and defendants won. Id. By that time, however, plaintiff had sued the defendants again, alleging that they had violated the antitrust laws by agreeing not to settle the infringement case separately in order to present a common front. See Lemelson v. Bendix Corp., 104 F.R.D. 13 (D. Del. 1984) (discovery motion in same case). The partial vacation and remand of the decision in the infringement case, see Lemelson v. United States, 752 F.2d 1538 (Fed. Cir. 1985), may make the antitrust case seem less extraordinary, but plaintiffs claim was not premised on that. Instead, his premise was that the Sherman Act protected his opportunity to parlay his invalid patent claim into the best possible settlement by playing the defendants off against one another. Eventually, after three years of litigation, the court granted summary judgment to defendants in the antitrust case on the ground plaintiff had insufficient evidence of an illegal conspiracy. See Lemelson v. Bendix Corp., 621 F. Supp. 1122 (D. Del. 1985).

In other contexts, the litigation value of an invalid claim has also been given protection. Thus, in Aloy v. Mash, 38 Cal. 3d 413, 696 P.2d 656, 212 Cal. Rptr. 162 (1985), the court held that failure to assert a claim which was shown by later decisions to be invalid could nonetheless be actionable malpractice. The defendant lawyer had represented plaintiff in her divorce in 1971 and had not then asserted a claim that the husband's military pension was community property. In 1981, the United States Supreme Court decided that states could not award interests in such pensions as community property, so the claim would not have been meritorious. But the California court was unmoved by this fact, reasoning that given the uncertainty of the pre-1981 law, the claim, though now known to be meritless, could then have had litigation value, so that the lawyer could be liable for failure to assert it.

58. 421 U.S. 723 (1975).

59. 1d. at 741 .

60. Id. at 740; see also Reiter v. Sonotone Corp., 442 U.S. 330, 345 (1979) (Courts "must be especially alert to identify frivolous claims brought to extort nuisance settlements."). 
themselves. After extensive debate, the Rules were amended in 1980 and 1983 to promote active case management through pretrial conferences that could "formulate issues" and eliminate "frivolous claims and defenses" and control the conduct and content of discovery. ${ }^{61}$ No longer does Rule 26(a) invite unlimited discovery; the judge is now explicitly authorized to limit discovery that is duplicative or "unduly burdensome or expensive" to protect the parties' right to a reasonably economical decision on the merits. ${ }^{62}$ The amended Rules also place greater emphasis on the duty of lawyers to avoid abuse of litigation by requiring an attorney to investigate both the legal and factual basis of a claim before filing suit, and by promoting increased use of sanctions for violation of various rules. ${ }^{63}$ Courts have begun using sanctions energetically, perhaps too energetically, ${ }^{64}$ to punish those who bring or maintain groundless suits, ${ }^{65}$ an effort that may deter some groundless litigation. ${ }^{66}$ The recent amendments do not, however, abandon the premise that lawsuits should be decided on their merits rather than technicalities.

\section{The Revival of Fact Pleading}

Oh, you might say, we have motions to dismiss-rule 12(b)(6), the vaunted motion to dismiss for failure to state a claim upon which relief can be granted. It is a wonderful tool on paper, but have you ever looked at the batting average of rule

61. Fed. R. Civ. P. 16(c)(1), 26(b), (f). For a review of the 1983 amendments, see Marcus, Reducing Court Costs and Delay: The Potential Impact of the Proposed Amendments to the Federal Rules of Civil Procedure, 66 Judicature 363 (1983). See generally Elliott, Mangerial Judging and the Evolution of Procedure, 53 U. Chi. L. Rev. (forthcoming I986) (managerial judging as an ad hoc method for narrowing issues). For an example of the emphasis on this approach, see United Food \& Commercial Workers v. Armour \& Co., 106 F.R.D. 345, 349 (N.D. Cal. 1985) (endorsing telephone conference to establish baselessness of complaint); cf. Portsmouth Square, Inc. v. Shareholders Protective Comm., 770 F.2d 866, 869 (9th Cir. 1985) (sua sponte grant of summary judgment at final pretrial conference).

62. See Fed. R. Civ. P. 26(b)(1).

63. See Fed. R. Civ. P. 11, 16(f), 26(g); Marcus, supra note 61, at 369-70.

64. Cf. Curtin, Chairman's Corner, 10 Litig. News, Winter 1985, at 2 (reporting views of Professor Arthur Miller that, with respect to sanctions, "the pendulum might swing too far in the other direction" because "judges might impose too many sanctions rather than too few."). In his annual report to the judiciary, however, Chief Justice Burger urged more frequent use of sanctions. Burger Says Vacancies Add to Judicial Deficit, N.Y. Times, Dec. 30,1985 , at 12 , col. 1 .

65. See, e.g., Olympia Co. v. Celotex Corp., 771 F.2d 888, 892-94 (5th Cir. 1985); Eastway Constr. Corp. v. City of New York, 762 F.2d 243, 251-54 (2d Cir. 1985); Huettig \& Schromm, lnc. v. Landscape Contractors Council, 582 F. Supp. 1519 (N.D. Cal. 1984); Van Berkel v. Fox Farm \& Road Mach., 581 F. Supp. 1248 (D. Minn. 1984).

66. See, e.g., Conard, Winnowing Derivative Suits Through Attorneys leces, 47 law \& Contemp. Probs., Winter 1984, at 269, 284-85; Rowe, Predicting the Ellects of Attorney Fee Shifting, 47 Law \& Contemp. Probs., Winter 1984, at 139, 161. 
12(b)(6) motions? I think it was last effectively used during the McKinley administration.

\section{Professor Arthur R. Miller67}

Amidst the tumult surrounding the litigation boom, there has been almost no talk of changing the Federal Rules of Civil Procedure governing pleading. ${ }^{68}$ The last serious proposal was in the early $1950 \mathrm{~s}$, when the Ninth Circuit, in what has been described as a "guerrilla attack" 69 on simplified pleading, urged that Rule 8(a)(2) be amended to revive code pleading by requiring the plaintiff to allege "the facts constituting a cause of action."70 During the same period, several district judges in the Southern District of New York were engaged in what Clark himself characterized as "something bordering on a revolt" against the existing rule. ${ }^{71}$ The Advisory Committee on the Civil Rules rejected the proposed change, ${ }^{72}$ and Conley $v$. Gibson seemed to scotch the effort to revert to code practice.

Undoubtedly, lax pleading has, like the procedural and substantive changes discussed above, ${ }^{73}$ benefitted plaintiffs. Plaintiffs have an incentive to plead vaguely in hopes that discovery will turu up material on

67. A. Miller, The August 1983 Amendments to the Federal Rules of Civil Procedure: Promoting Effective Case Management and Lawyer Responsibility 7-8 (1984).

68. E.g., National Commission Staff Paper, The Early Narrowing and Resolution of Issues, 48 Antitrust L.J. 1041, 1056 (1980) ("There has been little testimony or comment presented to the [National] Commission [for Review of the Antitrust Laws] favoring increased specificity in antitrust pleadings.") (footnote omitted).

69. R. Field, B. Kaplan \& K. Clermont, Materials For a Basic Course in Civil Procedure 439 (5th ed. 1984).

70. See Claim or Cause of Action: A Discussion on the Need for Amendment of Rule 8(a)(2) of the Federal Rules of Civil Procedure, 13 F.R.D. 253, 253 (1952).

71. Clark, Special Pleading in the "Big Case," 21 F.R.D. 45, 49 (1957). These judges began in the early 1950 s to insist on more specific pleadings in large cases, particularly antitrust cases. See Baim \& Blank, Inc. v. Warren-Connelly Co., 19 F.R.D. 108, 109-10 (S.D.N.Y. 1956). In Nagler v. Admiral Corp., 248 F.2d 319 (2d Cir. 1957), the Second Circuit, speaking through Chief Judge Clark, rejected this movement: "[I]t is quite clear that the federal rules contain no special exceptions for antitrust cases." Id. at 322-23.

Coupled with the Supreme Court's pronouncement the same year in Conley v. Gibson, 355 U.S. 41 (1957), Nagler ended the debate in the courts, but the participants continued it elsewhere. Thus, Judge Dawson, the author of Baim $\varepsilon^{2}$ Blank, Inc., later commented: "The anti-trust bar was beginning to understand the necessity for this type of pleading in those cases . . . until Judge Clark made his speech at the Seminar [on Protracted Cases] last year and then followed it up with his decision in Nagler v. Admiral Corporation . . . Dawson, The Place of the Pleading in the Proper Definition of the lssues in the "Big Case," 23 F.R.D. 430, 434 (1958). Clark responded to "Judge Dawson's slashing attack" in Clark, Comment on Judge Dawson's Paper on the Place of the Pleading in the Proper Definition of the Issues in the "Big Case," 23 F.R.D. 435 (1958).

72. See Report of Proposed Amendments to the Rules of Civil Procedure for the United States District Courts 18-19 (1955) (explaining decision not to modify Rule $8(a)(2))$.

73. See supra notes $49-54$ and accompanying text. 
which to base a more specific charge. ${ }^{74}$ Indeed, it has even been suggested that specificity inherently favors defendants. ${ }^{75}$ Moreover, under Conley $v$. Gibson courts may be inclined to deny motions to dismiss precisely because they cannot tell enough about a plaintiff's claim from the pleadings to decide whether the plaintiff has a chance of prevailing at trial. As the Supreme Court noted in Blue Chip Stamps, ${ }^{76}$ plaintiffs with weak claims have good reason to want to stave off dismissal in hopes of a settlement.

A natural antidote to pro-plaintiff biases and the impulse toward vagueness is to promote pleadings decisions, and the courts have adopted this solution in areas that were viewed as particularly troubling. The Supreme Court itself, while approaching pleading issues with what has been called "appalling casualness" 77 and continuing outwardly to adhere to Conley, ${ }^{78}$ has nevertheless provided some support for such creativity. It has suggested that "insubstantial" cases can be dismissed despite "artful pleading"79 and appeared receptive to using pleading motions to weed out meritless cases. In a I983 decision reversing dismissal of an antitrust case, for example, it exhorted the district court to require plaintiff to plead with particularity, concluding that "in a case of this magnitude, a district court must retain the power to insist upon some specificity in pleading before allowing a potentially massive factual controversy to proceed." 80

Perhaps taking its own advice about the value of specificity, the Court has relied increasingly on fact pleading to resolve standing issues. In a 1975 decision, for example, the Court rejected plaintiffs' standing allegations as "conjectural" and "conclusory."81 Such allega-

74. Judges are not oblivious to this tendency toward vagueness. See, e.g., Levitch v. Columbia Broadcasting Sys., 94 F.R.D. 292, 294 (S.D.N.Y. 1982) (dismissing amended complaint characterized as "an effort [by plaintiffs] to keep their claim as ambiguous as possible"), aff d, 697 F.2d 495 (2d Cir. 1983); Weinstein, Proposed Revision of New York Civil Practice, 60 Colum. L. Rev. 50, 72 (1960) ("[T]he federal rules provide no protection against the unskilled and the skillful obscurers."). Clark certainly had no intention of fostering a shift to vagueness. See C. Clark, supra note 31, § 41, at 253 ("[W]e should not put a premium upon ignorance, so that the pleader who knows the least about his case will be the most protected by his pleading.").

75. See Friedenthal, supra note 10 , at 815 . On the other hand, it may be that defendants resist more vigorously when plaintiffs allegations are vague. See Kingdon, The "Big Antitrust Case": Thoughts on Procedural Reform, 37 Wash. \& Lee L. Rev. 25, 38 (1980); cf. Brazil, Kahn, Newman \& Gold, Early Neutral Evaluation: An Experimental Effort to Expedite Dispute Resolution, 69 Judicature 279, 279 (1986) (notice pleading makes early settlement difficult because true center of dispute cannot be identified).

76. Blue Chip Stamps v. Manor Drug Stores, 421 U.S. 723 (1975); see supra notes 58-60 and accompanying text.

77. Roberts, supra note 12 , at 399 .

78. See, e.g., Hishon v. King \& Spalding, 104 S. Ct. 2229, 2233 (1984).

79. Butz v. Economou, 438 U.S. 478, 507 (1978) (dictum).

80. Associated Gen. Contractors, lnc. v. California State Council of Carpenters, 459 U.S. 519,528 n.17 (1983) (dictum).

81. Warth v. Seldin, 422 U.S. $490,503,509$ (1975). 
tions were insufficient, the Court explained without reference to Conley v. Gibson, because they were not supported by "particularized allegations of fact" and "specific, concrete facts" showing harm to plaintiffs. ${ }^{82}$

Many lower courts have been even more vigorous in insisting on fact pleading. Although special pleading rules are sometimes used to accomplish a narrow policy objective, ${ }^{83}$ these decisions generally fit into one of three categories.

1. Securities Fraud. - Virtually unknown when the Federal Rules were adopted, ${ }^{84}$ securities fraud cases have since proliferated. Many courts have responded by requiring plaintiffs to plead detailed facts. To some extent this insistence can be justified by the special pleading requirements of Rule $9(\mathrm{~b})$, which requires that in fraud cases "the circumstances constituting fraud . . . shall be stated with particularity." 85 Clark, who viewed this Rule as a compromise with judges' habits, said it "probably states only what courts would do anyhow." 86 The Rule does not overturn the general thrust of the Federal Rules to avoid pleading battles and promote decisions on the merits in their place. ${ }^{87}$

82. Id. at 501, 508. Two years earlier, the Court had shown a preference for deferring standing decisions until the summary judgment stage. See United States v. Students Challenging Regulatory Agency Procedures (SCRAP), 412 U.S. 669, 689-90 (1973). For a criticism of the use of pleading to resolve standing issues, see Roberts, supra note 12.

83. The Ninth Circuit adopted a special pleading rule in cases involving activity arguably protected by the first amendment. See Franchise Realty Interstate Corp. v. San Francisco Local Joint Executive Board of Culinary Workers, 542 F.2d 1076, 1083 (9th Cir. 1976) ("[T]he danger that the mere pendency of the action will chill the exercise of First Amendment rights requires more specific allegations than would otherwise be required."), cert. denied, 430 U.S. 940 (1977). Arguably, this insistence on greater specificity in pleading to protect first amendment interests should be reexamined in light of Calder v. Jones, 465 U.S. 783, 790-91 (1984) (rejecting argument that first amendment concerns should limit scope of personal jurisdiction), and Herbert v. Lando, 441 U.S. 153 (1979) (rejecting argument that first amendment provides basis for privilege against discovery into editorial process in libel action).

84. The first case recognizing a private cause of action for damages under rule 10b5 was Kardon v. National Gypsum Co., 69 F. Supp. 512 (E.D. Pa. I946).

85. Fed. R. Civ. P. 9(b).

86. Clark, Simplified Pleading, 2 F.R.D. 456, 463 (1943).

87. The commentators have roundly rejected the formalistic argument that rule 9(b) erects a special regime immune to the liberal pleading approach of rule 8. E.g., 5 C. Wright \& A. Miller, supra note $3, \S 1298$, at 406 (rule 9(b) must be read in conjunction with rule 8); 2A Moore's Federal Practice, supra note 40, If 9.03, at 9-28 (same). Even the Second Circuit, most active in expansive use of rule $9(\mathrm{~b})$, has on occasion recognized this. See Felton v. Walston \& Co., 508 F.2d 577, 581 (2d Cir. 1974) ("'[I]n applying rule $9(\mathrm{~b})$ we must not lose sight of the fact that it must be reconciled with rule 8 . . . "). Moreover, the actual emphasis in many cases on detailed evidence supporting allegations about the defendant's state of mind, see infra notes 90-93 and accompanying text, is forbidden by the second sentence of rule $9(\mathrm{~b})$, which explicitly permits general pleadings to state of mind. See infra note 216 and accompanying text.

Nor is the use of rule $9(\mathrm{~b})$ to permit expansive pleadings decisious justified on policy grounds. First, the disfavored claims idea, which is one historical antecedent of rule 
Consistent with the general purposes of the Rules, some courts find that Rule 9(b) is designed to provide somewhat more specific notice and that it requires only "slightly more" detail than Rule 8(a)(2). ${ }^{88}$ However, other courts, particularly the Second Circuit, find that Rule 9(b) serves a much more substantive purpose-to protect defendants' reputations from unfounded claims of fraud and to assure that such malodorous claims are not filed as a pretext for discovery: "It is a serious matter to charge a person with fraud and hence no one is permitted to do so unless he is in a position and is willing to put himself on record as to what the alleged fraud consists of specifically." "Bo

The stricter courts pay great attention to "conclusory" allegations about defendants' knowledge or intent. Some hold that plaintiffs may not rely on allegations based on information and belief. ${ }^{90}$ Some insist that the plaintiff provide specific details that support factual conclusions. For example, in Ross v. A.H. Robins Co., ${ }^{91}$ plaintiff shareholders sued the company and its senior officers. Plaintiffs claimed that the defendants had knowingly or recklessly failed to disclose the health risks caused by use of the Dalkon Shield intrauterine device that eventually resulted in the filing of hundreds of lawsuits against Robins, with total claims far exeeding Robins' net worth. ${ }^{92}$ In their complaint, plaintiffs, who bought their shares in 1973, alleged that Robins had then touted the device as a boost to the company's financial health even though in

9(b), see 5 C. Wright \& A. Miller, supra note $3, \S 1296$, at 400 , simply fails to justify the new fact pleading. See infra notes 228-38 and accompanying text. Second, the courts' effort to erect special protections against charges of fraud, see infra note 89 and accompanying text, does not explain why fraud should be treated differently from other claims such as racketeering, racial discrimination, price-fixing, and environmental pollution, for which there are no special pleading rules. See infra notes 237-38 and accompanying text. Finally, and most importantly, in many cases fact pleading provides no reliable mechanism for evaluating a plaintiff's factual conclusions. Fact pleading therefore threatens the objectives of promoting reliable decisions on the merits and avoiding pleading battles. See infra notes 196-227 and accompanying text. Both from the perspective of the rules governing pleading and more generally in terms of the overall purpose of the rules, then, the presence of special pleading provisions does not justify the new fact pleading even in the area of fraud.

88. Sec, e.g., Tomera v. Galt, 511 F.2d 504, 508 (7th Cir. 1975); cf. Walling v. Beverly Enter., 476 F.2d 393, 397 (9th Cir. 1973) (Rule 9(b) only requires that circumstances constituting fraud be pleaded with sufficient particularity so that defendant can prepare an answer, and does not require pleading of detailed evidentiary matters.).

89. Segal v. Gordon, 467 F.2d 602, 607 (2d Cir. 1972) (quoting 1A W. Barron \& A. Hotzhoff, Federal Practice and Procedure $\S 302$, at 215-16 (Wright rev. 1960)); see also Billard v. Rockwell Int'l Corp., 683 F.2d 51, 57 (2d Cir. 1982) (Rule 9(b) construed strictly to minimize strike suits). For criticism of this use of Rule 9(b), see Sovern, supra note 12 , at $165-71$; Note, supra note 12 , at $1439-47$.

90. See, e.g., Wayne Inv., Inc. v. Gulf Oil Corp., 739 F.2d 11, 13-14 (1st Cir. 1984); Duane v. Altenburg, 297 F.2d 515, 518-19 (7th Cir. 1962).

91. 607 F.2d 545 (2d Cir. 1979), cert. denied, 446 U.S. 946 (1980).

92. In fact, Robins has recently sought protection from these suits by filing a petition under Chapter 11 of the Bankruptcy Code. See Robins Files for l'rotection of Chapter 11, Wall St. J., Aug. 22, 1985, at 3, col. 1. 
May, 1974, the company wrote 120,000 doctors across the country warning them of health hazards associated with the use of the device. To bolster their claim that defendants had known or recklessly disregarded these risks prior to plaintiffs' purchase of their shares in 1973, plaintiffs pointed to an unpublished 1972 study detailing the health hazards associated with the Dalkon Shield. Because plaintiffs did not allege Robins was aware of the study, however, the Second Circuit found the complaint inadequate for failure to "specifically plead those events which they assert give rise to a strong inference that defendants had knowledge of the facts." 93

2. Civil Rights Cases. - Like securities fraud cases, civil rights suits have since 1938 become a staple of the federal courts' civil docket. Unlike securities fraud cases, however, there is no special provision of the Federal Rules applicable to civil rights claims. Many lower federal courts have nevertheless revived fact pleading requirements in such cases.

The leader in this movement has been the Third Circuit, which is forthright about its motivation: "In recent years there has been an increasingly large volume of cases brought under the Civil Rights Act. . . . It is an important public policy to weed out the frivolous and insubstantial cases at an early stage in the litigation ...." "94 To achieve this objective most courts now declare that conclusory allegations are inadequate to state a civil rights claim. They require specific delineation of the facts claimed to show a violation of plaintiff's civil rights $^{95}$ and, as in securities fraud cases, focus particularly on plaintiff's allegations about intent. ${ }^{96}$

These requirements have been applied with remarkable enthusiasm. In United States $v$. City of Philadelphia, ${ }^{97}$ for example, the Department of Justice filed a complaint alleging in part that the Philadelphia police department systematically violated the civil rights of minority persons by abusing them physically. The complaint was signed by several government lawyers, including the Attorney General.98 Citing, among other things, the potential that such a claim could be vexatious to local police officials, the trial court dismissed. ${ }^{99}$ Although it specifically disavowed any need to determine whether the claim was frivo-

93. 607 F.2d at 558.

94. Rotolo v. Borough of Charleroi, 532 F.2d 920, 922 (3d Cir. 1976) (quoting Valley v. Maule, 297 F. Supp. 958, 960 (D. Conn. 1968)).

95. See, e.g., Jones v. Community Redevelopment Agency, 733 F.2d 646, 649 (9th Cir. 1984). See generally Roberts, supra note 12, at 417-19 (canvassing civil rights pleading cases).

96. See, e.g., Albany Welfare Rights Org. Day Care Center, Inc. v. Schreck, 463 F.2d 620, 623 (2d Cir. 1972) (upholding dismissal for failure adequately to allege defendant's motivation), cert. denied, 410 U.S. 944 (1973).

97. 644 F.2d 187 (3d Cir. 1980).

98. Id. at 205.

99. 482 F. Supp. 1274, 1278 (E.D. Pa. 1979), aff'd, 644 F.2d 187 (3d Cir. 1980). 
lous, ${ }^{100}$ the Third Circuit affirmed on the ground that the complaint did not satisfy the specificity requirement for civil rights cases, which it said was necessary to provide "fair notice" and to dispose of frivolous cases. ${ }^{101}$

3. Conspiracy. - Concerns about conspiracy seem pervasive today, and many plaintiffs include conspiracy allegations in their complaints. As Heart Disease Research Foundation v. Ceneral Motors Corp. ${ }^{102}$ shows, the lower courts also scrutinize conspiracy allegations with care. In general, they say that broad, vague charges of conspiracy do not suffice. ${ }^{103}$ Some require, at a minimum, that the plaintiff enumerate the overt acts alleged to show that the conspiracy existed. ${ }^{104}$

4. Summary: The Persistent Themes. - The situations in which the new fact pleading has been applied possess siguificant common characteristics. For one, they represent important segments of activity in the litigation boom, each type of claim having experienced enormous growth since the Federal Rules were adopted. ${ }^{105}$ More significantly, however, these situations present particularly difficult problems involving the potential abuse of litigation because they often involve outwardly innocent or admitted behavior that can, depending on the defendant's state of mind, result in very substantial liability. In a typical securities case, for example, the dispute is not over the content of the representations made by the defendants, but rather whether those representations were inaccurate and, if inaccurate, whether defendants knew or should have known of such inaccuracy. In the paradigmatic employee's civil rights suit, the dispute is not over whether defendants have fired the plaintiff, but rather their motivation for doing so. In many antitrust cases, the dispute is not over what happened to the

100. 644 F.2d at 205 n.28; cf. P. Marcus, The Big Antitrust Case in the Trial Courts, 37 Ind. L.J. 51, 61 (1961) ("The writer is not aware of the filing of a government antitrust suit where there was not sufficient knowledge of facts to warrant an honest belief that a violation of the Sherman Act existed.") (emphasis added).

101. 1d. at 205-06. In view of the change of administration in Philadelphia (Mayor Rizzo was replaced) and the imminent change of administrations in Washington, the Carter administration decided not to seek Supreme Court review. See O. Fiss \& D. Rendleman, Injunctions 56 (2d ed. 1984).

102. 463 F.2d 98 (2d Cir. 1972); see supra text accompanying notes 13-18.

103. See, e.g., Fullman v. Graddick, 739 F.2d 553, 557 (11th Cir. 1984); California Dump Truck Owners Assoc., Inc. v. Associated Gen. Contractors, 562 F.2d 607, 615 (9th Cir. 1977); Burnett v. Short, 441 F.2d 405, 406 (5th Cir. 1971). But see Quinones v. Szorc, 771 F.2d 289, 291 (7th Cir. 1985); Hoffman v. Halden, 268 F.2d 280, 294-95 (9th Cir. 1959) ("Hoffman also alleges the 'defendants conspired.' In what other way can plaintiff plead conspiracy? . . He should not be required here to plead his evidence.").

104. See Powell v. Workmen's Compensation Bd., 327 F.2d 131, 137 (2d Cir. 1964), and cases cited therein.

105. This is not to say that strict fact pleading requirements were unknown in such cases before the 1960s. See, e.g., Dunn v. Gazzola, 216 F.2d 709, 711 (1st Cir. 1954) (rejecting allegation of conspiracy not supported by facts); Connor v. Real Title Corp., I65 F.2d 291, 294 (4th Cir. 1947) (same). 
plaintiff, but rather whether whatever happened resulted from an agreement or conspiracy among the defendants. Given the breadth of potential discovery on issues like intention and knowledge, it is understandable that some courts have attempted to weed out groundless cases at the outset.

\section{Notice Pleading}

Whatever the earlier function of pleadings, the stated modern justification is limited to notice. Conley $v$. Gibson ${ }^{106}$ itself appeared to endorse the notice pleading idea, ${ }^{107}$ which the Supreme Court had previously suggested was the sole purpose of pleadings. ${ }^{108}$ Since Conley, the received learning has been that the function of pleadings is to give notice. ${ }^{109}$ Even where Rule 9 (b)'s particularity requirement applies, some courts routinely deny pleading motions if they believe defendant has sufficient notice to prepare an answer, ${ }^{110}$ sometimes even though the complaint itself fails to provide notice. ${ }^{111}$ According to this approach, defendant's desire for further information about plaintiff's claims should be handled later through discovery and other pretrial procedures. ${ }^{112}$

But notice pleading is a chimera. Within a year after Conley, Clark himself described it as "something like the Golden Rule, which is a nice hopeful thing; but . . . isn't anything that we can use with any precision." 13 More fundamentally, one may ask why it should be used at

106. 355 U.S. $41,47-48$ (1957).

107. See id. (referring to "simplified 'notice pleading' [that] is made possible by the liberal opportunity for discovery and the other pretrial procedures established by the Rules to disclose more precisely the basis of both claim and defense and to define more narrowly the disputed facts and issues") (footnote omitted).

108. See Hickman v. Taylor, 329 U.S. 495, 501 (1947) (Federal Rules "restrict the pleadings to the task of general notice-giving.").

109. See supra note 40 and accompanying text.

110. See, e.g., Bosse v. Crowell, Collier \& Macmillan, 565 F.2d 602, 611 (9th Cir. 1977) ("Rule 9(b) . . . only requires the identification of the circumstances constituting fraud so that the defendant can prepare an adequate answer from the allegations ....").

111. See, e.g., In re Commonwealth Oil/Tesoro Petroleum Corp. Sec. Litig., 467 F. Supp. 227, 251 (W.D. Tex. 1979) (Rule 9(b) does not "require plaintiffs repeatedly to redraft pleadings" when the defendants have "pre-existing full knowledge of the matters which plaintiffs' pleading addresses. Therefore, . . . even though plaintiffs' pleadings are vague, [where] the defendants do in fact have notice of the matters of which plaintiffs complain, a strict application of Rule 9(b) can serve no purpose."); cf. Whittier, Notice Pleading, 31 Harv. L. Rev. 501, 505 (1918) (" $[\mathrm{I}] \mathrm{f}$ the opponent does understand the pleader's claim, whether that be the result of the pleading itself or partly due to the opponent's own knowledge, he is obviously not entitled to particulars."). How the court is to determine whether the defendant has sufficient knowledge indepedent of the pleadings, however, is something of a mystery.

112. See C. Wright, The Law of the Federal Courts § 68, at 439 (4th ed. 1983); supra note 107.

1 I3. Clark, Pleading Under the Federal Rules, I2 Wyo. L.J. 177, 18I (1958). Some 
all. Providing notice would seem, after all, to be the function of a motion for a more definite statement under Rule 12(e), which is allowed when a pleading "is so vague or ambiguous that a party cannot reasonably be required to frame a responsive pleading."114 But a defendant hardly needs specificity to deny a vague allegation, ${ }^{115}$ and will rarely be unable to raise a legitimate affirmative defense due to vagueness of the pleadings. To take a common example, defendants can preserve statute of limitations defenses by alleging in their answers that plaintiffs' claims are barred, in whole or in part, by limitations. ${ }^{116}$ Moreover, if ambiguity of pleadings has obscured an affirmative defense, courts will rarely refuse an amendment to add the defense once discovery has shown it to be applicable. ${ }^{117}$ Accordingly, it would seem that the defendant always has enough notice to be able to prepare an answer.

More detailed pleadings are similarly unimportant in relation to other pretrial activities. Although they may pinpoint an opposing party's view of the facts somewhat, they are hardly substitutes for examination by deposition. Moreover, as the opposing party obtains more information through discovery, his view of the facts is likely to evolve. In practice, discovery itself is often difficult to limit to specific factual allegations, and the liberal amendment provisions of the Rules would be undermined by efforts to imprison the plaintiff within detailed initial assertions.

Balanced against the marginal utility of more detailed notice ${ }^{18}$ is

have suggested, however, that these views represent something of a political retreat by Clark, not a modification of his basic view. See Smith, supra note 3, at 925-26.

114. Fed. R. Civ. P. 12(e).

115. It is true that Fed. R. Civ. P. 8(b) imposes a good faith requirement not to deny matters known to be true, but it also says that where the pleader "is without knowledge or information sufficient to form a belief as to the truth of an averment, he shall so state and this has the effect of a denial." As a general matter, then, where the defendant is uncertain about the law or the facts on which the plaintiff relies, it may deny. See Shultz v. Manor House of Madison, Inc., 51 F.R.D. 16, 17-18 (W.D. Wis. 1970).

116. See 2A Moore's Federal Practice, supra note 40, I 12.18, at 12-145 to 12-146.

117. Fed. R. Civ. P. 15(a) directs that leave to amend be "freely given." The Supreme Court has indicated this means amendment should be allowed in the absence of bad faith or undue delay by the moving party. See Foman v. Davis, 371 U.S. 178, 182 (1962); see also supra note 42 and accompanying text. This same liberality applies to amendments of answers to add affirmative defenses. See, e.g., Glater v. Eli Lilly \& Co., 712 F.2d 735, 738-39 (1st Cir. 1983).

118. For a recent example of the minimal importance the Supreme Court attaches to notice in other contexts, consider Brandon v. Holt, 105 S. Ct. 873 (1985). Plaintiffs, injured by a policeman, sued the director of the police department for failure to fire the officer for previous misconduct. Although plaintiffs obtained a judgment, the court of appeals reversed on the ground that the director was protected by qualified immunity because he was not personally aware of the officer's tendencies and thus was acting in good faith.

The Supreme Court reversed, holding that a judgment against a public servant in his official capacity imposes liability on the entity he represents. The Court held that judgment should be entered against the city itself because even though the city had never been named as a defendant it could be added under Rule 15(b) as an amendment 
the substantial cost of pleading practice designed to elicit additional details. Dilatory motions remain a problem, ${ }^{119}$ and motions seeking an emendation of the complaint seem peculiarly susceptible to abuse due to their potential for delay. For example, in Ross v. A.H. Robins Co. ${ }^{120}$ while the Second Circuit faulted plaintiff's pending complaint for lacking facts "strongly supporting" the inference defendants knew about the dangers of the Dalkon Shield, it also remanded to give them another chance to do so. They evidently succeeded, and the case remained on the district court's docket for at least another four years. ${ }^{121}$ Neither the early motion practice nor the appeal seem to have advanced the case meaningfully toward ultimate resolution.

This is not to say either that specifics and precision are undesirable, or that no complaints are so opaque that redrafting is necessary in order to apprise the defendant of the nature of the plaintiff's grievance. ${ }^{122}$ In general, however, pleading motions are unlikely to advance the litigation process in a meaningful way unless they provide some hope of leading to a resolution of the case on the merits. Early resolution on the merits is the objective of the Rule 12(b)(6) motion to dismiss for failure to state a claim. The 12(b)(6) motion should not be diluted into a variant of the motion for a more definite statement. ${ }^{123}$ Indeed, some courts use the more definite statement to expose defects in the claim that would permit dismissal. ${ }^{124}$ To require the courts to approach this objective indirectly, using the language of notice plead-

to conform to proof. Id. at 877-78. Justice Rehnquist dissented on the ground that Rule 15(b) had not been satisfied by plaintiffs' one-sentence reference to amendment in their reply brief to the Supreme Court. Id. at 879 . Chief Justice Burger concurred in the judgment, noting: "[M]odern pleading is less rigid than in an earlier day, but it is not too much to ask that if a person or entity is to be subject to suit, the person or entity should be named. I agree with Justice Rehnquist that it is a dubious business to encourage such shoddy pleading practices, but the courts have crossed that bridge." Id.

I19. See Edelstein, The Ethics of Dilatory Motion Prctice: Time for Change, 44 Fordham L. Rev. 1069 (1976).

120. 607 F.2d 545 (2d Cir. 1979), cert. denied, 446 U.S. 946 (1980); see supra notes $91-93$ and accompanying text.

121. See Ross v. A.H. Robins Co., [1982-83 Transfer Binder] Fed. Sec. L. Rep. (CCH) \ 99,095 (S.D.N.Y. Feb. 14, 1983).

122. See, e.g., Mountain View Pharmacy v. Abbott Laboratories, 630 F.2d 1383, 1386-87 (10th Cir. 1980) (In a complex case, more details are necessary.).

123. See 5 C. Wright \& A. Miller, supra note $3, \S 1376$, at $732-34$ (motion for more definite statement is limited to a "quite small" class of cases in which court can discern a viable claim but the complaint is still "so vague or ambiguous that the opposing party cannot respond, even with a simple denial, in good faith and without prejudice to himself') (footnote omitted). As indicated supra notes 115-17 and accompanying text, it is doubtful any such cases really exist. At most, as Professors Wright and Miller conclude, the motion for a more definite statement "should be strictly limited to those few instances in which a significant advancement of the litigation will result." $5 \mathrm{C}$. Wright \& $\mathrm{A}$. Miller, supra note 3 , § 1376 , at 747 .

124. See 5 C. Wright \& A. Miller, supra note $3, \S 1376$, at 743-44 (discussing use of more definite statement to permit disposition on grounds of statute of limitations or Statute of Frauds); id. $\$ 1217$, at 131 (" $[\mathrm{C}]$ ourts often will use a motion directed at the 
ing, ${ }^{125}$ either obscures or deflects the proper inquiry. Moreover, once sufficient details are included to show that a legitimate claim has been stated, any notice objective should also have been satisfied. ${ }^{126}$ Notice should not be the sole, or even the principal, objective of pleadings practice. The proper focus should shift to merits dispositions.

\section{Merits Decisions}

Under the received tradition, the problem with common law pleading practice was that, while it led to actual decisions, it often did not lead to merits decisions because cases were frequently resolved on technicalities. The notice pleading scenario, by way of contrast, eliminates the possibility for even genuine merits decisions at the pleadings stage. The middle ground is to use pleading practice to make genuine and reliable merits decisions. Contrary to expectation, this activity is not dead, though it is often camouflaged in notice pleading language.

This Part examines the contemporary use of pleadings to decide cases on the merits, which is the ultimate effect of revived fact pleading. It begins by examining the key question: whether decisions at the pleading stage are to be preferred to settlements, which occur in most cases that are not dismissed before trial. Finding that such decisions are desirable in the abstract to achieve the objectives of the substantive law, it then explores situations where pleading practice can effectively resolve the merits-where legal conclusions relied on by the plaintiff can be shown to be groundless by requiring more factual detail in pleading. Finally, this Part explores the problem of scrutinzing plaintiff's factual conclusions, which is the focus of much of the new emphasis on fact pleading, and finds that this problem cannot sensibly be handled at the pleading stage. Accordingly, although merits resolution by pleading motion may in many cases be possible, it appears ill-suited for the kinds of cases in which the courts have been using fact pleading as an antidote to the ills of the litigation boom.

\section{A. Merits Decision Versus Settlement}

Most cases are never resolved by a court, on the merits or otherwise, because they are settled. ${ }^{127}$ Recently this statistic has kindled a

form of a pleading as a vehicle for considering whether any possible claim for rclief exists.").

125. See, e.g., Hayduk v. Lanna, 775 F.2d 441, 444 (1st Cir. 1985) (absencc of facts supporting claim that defendants conspired to defraud plaintiff deprives defendants of notice of basis of claims against them). See generally $5 \mathrm{C}$. Wright \& A. Miller, supra note $3, \S 1217$, at 131 (Courts use motions directed to the form of a complaint to determine whether any claim for relief exists.).

126. See supra notes 115-17 and accompanying text. Accordingly, some advocate eliminating the motion for a more definite statement altogether, leaving discovery to clarify vague claims. See 5 C. Wright \& A. Miller, supra note $3, \S 1376$, at 740 \& n.50.

127. This statistic is hardly new. Clark observed in 1935 that only $30 \%$ of federal 
debate between the proponents of the "dispute resolution" model of litigation and the advocates of the "public interest" model. Imported into the pleading practice area, the debate identifies the underlying issues.

Proponents of the public interest model oppose viewing the court system primarily as a lever or facilitator for essentially private dispute resolution. To some, this means that any resolution of a lawsuit except by judicial decision represents a failure of the judicial system. Professor Owen Fiss, a leading light in this camp, explains that " $[t] 0$ be against settlement is only to suggest that when the parties settle, society gets less than what appears, and for a price it does not know it is paying. Parties might settle while leaving justice undone."128 Although the proponents of the public interest view seem generally to have in mind a decision after a full dress trial, the reasoning appears to apply equally to pretrial judicial decisions, including pleading dispositions. Indeed, given the impossibility of actually trying all civil cases, logic seems to favor pretrial disposition.

The dispute resolution advocates, on the other hand, mistrust judicial resolution. Even judges openly question the desirability of complete resolution after trial as the generally preferred outcome. As one experienced federal judge put it in a seminar for new judges, "[o]ptimal justice is usually found somewhere between the polar positions of the litigants. Trial is likely to produce a polar solution, and often the jury or the judge has no choice except all or nothing. Settlement is usually the avenue that allows a more just result than trial."129

court civil cases then reached a court decision. Clark \& Moore, A New Federal Civil Procedure: Pleadings and Parties (pt. 2), 44 Yale L.J. 1291, 1294 \& n.8 (1935); cf. Galanter, The Emergence of the Judge as a Mediator in Civil Cases, 69 Judicature 256, 257 (1986) ("1t remains unclear whether the percentage of cases terminated by settlement has increased in recent years.").

128. Fiss, Against Settlement, 93 Yale L.J. 1073, 1085 (1984). He explains further:

I do not believe that settlement as a generic practice is preferable to judgment or should be institutionalized on a wholesale and indiscriminate basis. It should be treated instead as a highly problematic technique for streamlining dockets. Settlement is for me the civil analogue of plea bargaining . . . . Like plea bargaining, settlement is a capitulation to the conditions of mass society and should be neither encouraged nor praised.

Id. at 1075. Professor Fiss is generally opposed to treating courts primarily as dispute resolution forums. See Fiss, The Supreme Court, 1978 Term-Foreword: The Forms of Justice, 93 Harv. L. Rev. 1, 29 (1979) ("[C]ourts exist to give meaning to our public values, not to resolve disputes."). Despite Fiss' arguments, all plea bargaining need not be viewed as a failure of the judicial system. For an argument that the only constitutional concern with plea bargaining is that the innocent will plead guilty, see McCoy \& Mirra, Plea Bargaining as Due Process in Determining Guilt, 32 Stan. L. Rev. 887, 921-22 (1980). Similar concerns bear on the undesireability of settlements in civil cases. See infra notes 133-39 and accompanying text.

129. Tone, The Role of the Judge in the Settlement Process, in Seminars for Newly Appointed United States District Judges 57, 60 (1975); accord Coons. Approaches to Court Imposed Compromise-The Uses of Doubt and Reason, 58 Nw. U.L. Rev. 750. 
This view evinces great skepticism about the liberal ethos and its preference for judicial resolution on the merits. Instead, a settlement may be preferable, whatever the ultimate merits of the claim, ${ }^{130}$ so long as the plaintiff "firmly believes" he has a legitimate grievance against defendant. ${ }^{131}$ Arguably, then, dismissal on the pleadings would not be a desirable alternative. ${ }^{132}$

Thus, the two schools pose the core problem: Are pleadings decisions or settlements better? Denial of a motion to dismiss often means only that a defendant who will ultimately prevail must litigate longer. Even the confident defendant may decide to settle, however. To the extent that decision is made "in the shadow of the law" because it reflects a prediction of the substantive merits of the case, ${ }^{133}$ it accomplishes the objectives of the substantive law, albeit in a modified form because a settlement is not an "all or nothing" result. Freed of the burden of deciding the settled case, the court system is able to turn its attention to other cases, and there apply the substantive law.

The settlement model breaks down, however, when the defendant's payment to the plaintiff is based mainly on factors other than the substantive merits of the suit. ${ }^{134}$ This is the spectre which haunts the

751 (1964) (seeing the "judicial power to compromise between the often harsh alternatives of all-or-nothing" as promoting a "fair" decision that is unattainable by law).

130. Cf. Marek v. Chesny, 105 S. Ct. 3012, 3018 (1985) ("Rule 68's policy of encouraging settlements is neutral, favoring neither plaintiffs nor defendants; it expresses a clear policy of favoring settlement of all lawsuits.").

131. The phrase comes from Clark's famous opinion reversing a dismissal in Dioguardi v. Durning, 139 F.2d 774, 775 (2d Cir. 1944).

132. To some extent this preference for a negotiated over a judicial resolution is confirmed by the handling of prisoner cases, where the courts act because they have to. "Relatively few prison cases can be settled, primarily because meaningful negotiations between prisoners acting pro se and states' attorneys are practically impossible. Thus, unlike other civil litigation, some court action is required on almost all the cases." Turner, When Prisoners Sue: A Study of Prisoner Section 1983 Suits in the Federal Courts, 92 Harv. L. Rev. 610, 637 (1979). The dismissal rate in such cases is very high. 1d. at 617-18.

133. See Mnookin \& Kornhauser, Bargaining in the Shadow of the Law: The Case of Divorce, 88 Yale L.J. 950 (1979) (discussing role of legal rules in negotiation of settlements in divorce cases). Priest and Klein conclude that changes in the legal standard affect settlements, not outcomes, by shifting the bargaining advantage. Priest \& Klein, The Selection of Disputes for Litigation, $13 \mathrm{~J}$. Legal Stud. 1, 12-30 (1984). For a debate on the accuracy of their method, sce Priest, Reexamining the Selection Hypothesis: Learning from Wittman's Mistakes, 14 J. Legal Stud. 215 (1985); Wittman, Is the Selection of Cases for Trial Biased?, $14 \mathrm{~J}$. Legal Stud. 185 (1985); see also Galanter, supra note 46, at 32-33 (legal decisions radiate and affect settlement value of cases). But cf. Menkel-Meadow, Toward Another View of Legal Negotiation: The Structure of Problem Solving, 31 UCLA L. Rev. 754, 790-91 (1984) (definitive rulings deter innovative settlement packages).

134. See Simon, The Ideology of Advocacy: Procedural Justice and Professional Ethics, 1978 Wis. L. Rev. 29, 46-47:

[P]rocedure is not being used merely as a more efficient way of enforcing a substantive claim, but also as an instrument of private policy for the vindication 
liberal ethos. The financial burden of litigation is obviously an important factor, ${ }^{135}$ but it is not the only one. The pendency of a lawsuit imposes other costs that settlement can avert, whether or not the claim is well founded. In derivative suits, for example, the defendants' desire to avoid publicity ${ }^{136}$ and to reduce the time drain of litigation ${ }^{137}$ may incline them toward settlement. In antitrust cases, the unavailability of contribution may make the risk of litigation so great that settlement seems essential. ${ }^{138}$ Moreover, the value of a decision by a court deserves some deference; without a body of such decisions the law may not cast a discernible shadow for those who seek to rely on the law in fashioning settlements. ${ }^{139}$ Accordingly, pleadings decisions on the merits seem justified when they can be made reliably.

The pressure to encourage pleadings decisions is far from overwhelming, however, and there is much dispute about the extent to which nuisance settlements are in fact extracted. For example, although the class action procedure has been blamed for breeding vexatious litigation, existing empirical data do not show that the problem is severe. ${ }^{140}$ Litigation cost, the most-cited villain, has an ambivalent

of expectations which are not justified by the substantive law. . . In the vast majority of cases which are settled, there is not even a pretense that the result has been determined by the application of a system of substantive rules to given factual premises.

See also Eisenberg, The Principles of Consideration, 67 Coruell L. Rev. 640, 645 (1982) (labelling "trading on the transaction costs of litigation" as "moral extortion").

135. Thus, Judge Tone explains that "candidates for settlement" can easily be recognized: "They are the cases in which the amount involved is small in relation to the anticipated costs of litigation, or in which relief other than the payment of money is the plaintiff's principal objective and it is less painful for the defendant to give that relief than to bear the expense of further litigation." Tone, supra note 129 , at 62 . The distingnishing feature in these cases, it should be noted, is litigation cost, not strength or weakness on the merits.

136. See Jones, An Empirical Examination of the Resolution of Shareholder Derivative and Class Action Lawsuits, 60 B.U.L. Rev. 542, 546 (1980). The existence of such noneconomic stakes in litigation may, on the other hand, incline defendant against settlement. See Coffee, Understanding the Plaintiff's Attorney: The Implications of Economic Theory for Private Enforcement of Law Through Class and Derivative Actions, 86 Colum. L. Rev. (forthcoming May 1986).

137. See Coffee, The Unfaithful Champion: The Plaintiff as Monitor in Shareholder Litigation, 48 Law \& Contemp. Probs., Summer 1985, at 5, 15.

138. It is true that the absence of contribution reflects in part an assessment of Congress' substantive objectives in enacting the antitrust laws. See Texas Indus. v. Radcliff Materials, Inc., 451 U.S. 630, 639, 645-46 (1981) (court has no authority to provide for contribution in antitrust cases because Congress made contrary legislative judgment). But that judgment was hardly intended to leave one alleged conspirator facing a bankrupting liability to a plaintiff class after all the others have settled, a litigation reality that tends to deprive the defendant of any meaningful opportunity to defend. This reality explains the willingness of defendants to contract with one another for contribution, thereby reducing this settlement leverage. Sec Note, Sharing Agreements Among Defendants in Antitrust Cases, 52 Geo. Wash. L. Rev. 289 (1984).

139. See supra note 133 (discussing effect of legal rules on scttlements).

140. See DuVal, The Class Action as an Antitrust Enforcement Devicc: The 
effect. When the cost of litigating a meritorious claim is greater than the expected recovery, a suit filed in hopes of an early settlement may be characterized as a nuisance suit even though the claim has merit. ${ }^{141}$ Moreover, defendants can limit their costs. ${ }^{142}$ Accordingly, there is no compelling impetus toward radical change, and care is in order before concluding that a particular case can be reliably decided on the pleadings. ${ }^{143}$

Chicago Experience (pt. 2), 1976 Am. B. Found. Research J. 1273, 1344-46 (little indication that class allegations affect settlement value); Note, The Rule 23(b)(3) Class Action: An Empirical Study, 62 Geo. L.J. 1123, 1137 (1974) (even defense counsel label only a handful of class actions frivolous). But cf. Kennedy, Securities Class and Derivative Actions in the United States District Court for the Northern District of Texas: An Empirical Study, 14 Hous. L. Rev. 769, 824-26 (1977) (class allegations give plaintiff settlement leverage). Thus, concern about abuse of the class action device has abated. See Miller, Of Frankenstein Monsters and Shining Knights: Myth, Reality, and the "Class Action Problem," 92 Harv. L. Rev. 664 (1979).

141. See Rosenberg, The Causal Connection in Mass Exposure Cases: A "Public Law" Vision of the Tort System, 97 Harv. L. Rev. 849, 896 n.I71 (1984); Rosenberg \& Shavell, A Model in Which Suits Are Brought for Their Nuisance Value, 5 lnt'l Rev. L. \& Econ. 3 (1985).

142. Thus Robert Banks, General Counsel of Xerox Corp., reports that "corporate lawyers are working to decrease costs by focusing in on the net value of every motion, every pleading, every discovery." Annual Judicial Conference Second Judicial Circuit of the United States, 101 F.R.D. 161, 191 (1983); see also Smith, "Top-Dollar Clients" Can Limit Expenses, Legal Times, June 11, 1984, at 22, col. 2 (providing suggestions on how clients can economize on legal services).

143. One suggested antidote to the cost problem is cost shifting. Because the principal component of litigation expense is attorneys' fees, some urge that we adopt the English system of routinely awarding the winner his attorneys' fees. Under such a regime, one might argue that litigants should be allowed to make their litigation investment decisions without interference from possibly premature efforts to decide cases on motions to dismiss, and that such decisions should therefore be discouraged. For several reasons, increased cost shifting is not an alternative to early merits decisions.

First, reliance on economic decisions of litigants unduly devalues judicial decisionmaking as a device for clarifying rules of law. Without adopting Professor Fiss' view, sec supra note 128 and accompanying text, it remains true that litigants seeking to settle cases in the "shadow of the law" need judicial assistance in discerning the contours of that shadow. See supra text accompanying notes 133,139 . The small number of cases that are tried would not be sufficient for this purpose.

Second, despite the existence of a body of judicial decisions the law is often uncertain, and litigants must guess as best they can about the outcome of their suit. Denying them a prompt decision where it can reliably be made simply increases for no good reason the amount that will ultimately be imposed on the loser. In this connection, it is unclear whether adopting routine attorneys' fee awards would increase expenditures on litigation by increasing the stakes. See Braeutigam, Owen \& Panzar, An Economic Analysis of Alternative Fee Shifting Systems, 47 Law \& Contemp. Probs., Winter 1984, at $173,180-81$.

Third, awarding attorneys' fees does not, in many cases, fully compensate the winning party for noneconomic costs resulting from the suit. See supra notes 135-137 and accompanying text. Deferring decision would continue for no good reason to impose these uncompensated costs on a party who ultimately wins.

Fourth, the availability of attorneys' fees awards may stimulate the filing of some kinds of suits, thus increasing the need to scrutinize the grounds for such suits. Sec 


\section{B. Legal Conclusions: Implementing the Substantive Law}

Both sides of the settlement-dispute resolution controversy wish ultimately to implement the substantive law. That is, after all, the generally accepted objective of procedure. ${ }^{\mathbf{1 4 4}}$ But the substantive law may frustrate that goal in the pleading context by relying on rules that can only be applied with reference to a multitude of factors or factual matters that cannot be adequately assessed at the pleading stage. Whether or not it is inevitable that legal rules will become more uncertain over time, ${ }^{145}$ it is certainly true that the evolution of the law away from precise (and rather arbitrary) rules has reduced the utility of pleading decisions. ${ }^{146}$

A simple example illustrates this difficulty. Before 1938, the detail required to plead negligence was the subject of much dispute, a past the Federal Rules sought to bury with Form $9 .{ }^{147}$ But the underlying problem with pleading decisions was not really procedural. It was substantive because the negligence determination turned on such a variety of circumstances that it could not reliably be made on the basis of

Pulliam v. Allen, 466 U.S. 522, 555-56 (1984) (Powell, J., dissenting) (asserting that since enactment of Civil Rights Attorney's Fees Awards Act, 42 U.S.C § 1988 (1982), civil rights suits have "increased geometrically").

In sum, while fee shifting as a sanction may hold some promise, see supra note 66 and accompanying text, the prospect of greater private policing of the decision to file suit through economic incentives caused by fee shifting provides no reason for abandoning interest in refining the pretrial motion process.

144. The adoption of the Federal Rules was not intended to alter the outcome except to assure that it corresponds to the merits under what is understood to be the substantive law. Indeed, the Rules Enabling Act, 28 U.S.C. $\$ 2072$ (1982), precludes such tampering with substantive law. This Article proceeds on that understanding.

145. See D'Amato, Legal Uncertainty, 71 Calif. L. Rev. I, 1 (I983) ('Legal certainty decreases over time. Rules and principles of law become more and more uncertain in content and in application because legal systems are biased in favor of unravelling those rules and principles."); Epstein, Settlement and Litigation: Of Vices Individual and Institutional, 30 U. Chi. L. Sch. Rec. 2, 5-7 (1984) (complexity and uncertainty of modern substantive rules contribute to increase in frequency and severity of litigation). In part, the development can be seen as a shift from hard-and-fast "rules" to more flexible "standards." See Kennedy, Form and Substance in Private Law Adjudication, 89 Harv. L. Rev. 1685 (1976).

146. See Clark, supra note 71 , at 51 (The real problem with pleadings decisions in antitrust cases is that the Sherman Act is broad.); Epstein, Pleadings and Presumptions, 40 U. Chi. L. Rev. 556, 566 (1973) (referring to "the importance [in evaluating pleadings] of an exact knowledge of the substantive theory in question in order to distinguish ultimate issues of fact from the questions of proof that they raise"); Kingdon, supra note 75 , at 34 (lack of clear standards in antitrust field is one cause of vague pleading); $c f$. Miller, supra note 140, at 672-73 (watering down substantive rnles increases litigation). The same phenomenon can be seen at the summary judgment stage. See, e.g., Tunis Bros. v. Ford Motor Co., 763 F.2d 1482, 1502 (3d Cir. 1985) ("Under the 'rule of reason' standard, there is a greater reluctance to uphold a grant of summary judgment where the conduct is to be examined for its reasonableness than where it is to be subjected to a per se rule.").

147. See supra notes 31,36 and accompanying text. 
pleadings, whatever detail they contained. Had negligence law been atomized into a multitude of concrete subrules, the resulting emphasis on specific points could have permitted pleading decisions in many cases. It may be argued that the law has gone too far toward multifactor generality, ${ }^{148}$ but that problem is substantive, not procedural.

Nonetheless, the substantive law can provide tools that permit pleadings dispositions. The courts' handling of such cases falls generally into two categories: Cases in which the substantive law requires a certain element that is missing and cases in which the court, by carefully analyzing the totality of the plaintiff's allegations, can sensibly decide on the basis of the pleadings that the defendant did not violate the law.

1. Using Pleadings to Identify Missing Elements. - Although it may begin as an amorphous proscription, the substantive law can sharpen over time so that specific elements of a claim can be identified and applied at the pleading stage. For example, when the Supreme Court held in Blue Chip Stamps that securities fraud plaintiffs had to be purchasers or sellers, ${ }^{149}$ the lower courts had a new substantive tool to use in evaluating complaints. ${ }^{150}$ Similarly, when the Court held that only direct purchasers could sue for price fixing, ${ }^{151}$ the lower courts could entertain motions to dismiss suits by indirect purchasers. ${ }^{152}$ Just this last Term, the Court confirmed that misrepresentation or nondisclosure is a necessary element for a claim under the Williams Act, ${ }^{153}$ and the same process may be expected there.

The process works more actively in emerging areas of law. Consider, for example, the burgeoning civil litigation under the 1970 Racketeer Influenced and Corrupt Organizations Act (RICO), 154 which epitomizes the litigation boom. The statute, as one court put it, is "constructed on the model of a treasure hunt."155 In a provision little discussed in Congress, it authorizes a private action for treble damages, plus an award of attorneys' fees, for "[a]ny person injured in his business or property by reason of a violation." 156 The key triggering event for a violation is a "pattern of racketeering activity." 157 The statute forbids use of income from such an activity in operation of a business

148. For an argument that specificity in pleading could be useful in negligence cases, in conjunction with modifications in the substantive law, sce Epstcin, supra note 146, at 566 .

149. See supra notes 58-60 and accompanying text.

150. See, e.g., Sacks v. Reynolds Sec., Inc., 593 F.2d 1234, I239-41 (D.C. Cir. 1978) (dismissal pursuant to Blue Chip Stamps).

151. See Illinois Brick Co. v. Illinois, 431 U.S. 720 (1977).

152. See, e.g., Merican, Inc. v. Caterpillar Tractor Co., 713 F.2d 958, 965-69 (3d

Cir. 1983) (dismissal pursuant to Illinois Brick), cert. denied, 465 U.S. 1024 (1984).

153. Schreiber v. Burlington N., Inc., 105 S. Ct. 2458 (1985).

154. 18 U.S.C. §§ 1961-1968 (1982).

155. Sutliff, Inc. v. Donovan Cos., 727 F.2d 648, 652 (7th Cir. 1984).

156. 18 U.S.C. $\$ 1964$ (c) (1982).

157. Id. \& 1962. 
engaged in interstate commerce, ${ }^{158}$ acquiring a business through such activity, ${ }^{159}$ or participation in the conduct of the affairs of an enterprise through such activity. ${ }^{160}$ A "pattern of racketeering activity," in turn, requires the commission within ten years of two or more "predicate acts," which include violation of one of a series of criminal statutes. ${ }^{161}$ Since mail fraud ${ }^{162}$ and wire fraud ${ }^{163}$ are included in this list, "garden variety fraud" could be catapulted into a treble damage action with the addition of the lurid term "racketeering" to the complaint.

For about ten years after RICO was passed, the civil suit provisions languished. Around 1980, however, a wave of litigation under the statute began. This has caused an uproar in the courts. ${ }^{164}$ Some courts have tried to graft requirements onto the statute and dismiss cases that do not satisfy those requirements. Most notably, the Second Circuit decided that a RICO claim could not lie unless the defendant had been convicted of the predicate acts. ${ }^{165}$ Courts also dismissed cases for failure to allege links to organized crime, ${ }^{166}$ a special RICO injury, ${ }^{167}$ or an enterprise separate from the person accused of violating the Act. ${ }^{168}$ The Supreme Court has recently rejected certain of these elements, ${ }^{169}$

158. Id.

159. Id. § 1962(b).

160. Id. § I $962(\mathrm{c})$.

161. Id. $\S 1961(1)$. The pattern requirement has been interpreted to mandate something more than the predicate acts. See Northern Trust Bank/O'Hare, N.A. v. Inryco, Inc., 615 F. Supp. 828 (N.D. Ill. 1985) (predicate acts must show both continuity and relationship to each other).

162. 18 U.S.C. $\$ 1341$ (1982).

I63. Id. $\$ 1343$.

164. "Congress ... may well have created a runaway treble damage bonanza for the already excessively litigious." Schacht v. Brown, 711 F.2d 1343, I361 (7th Cir.), cert. denied, 464 U.S. 1002 (1983); see Pickholz, The Firestorm Over Civil RICO, A.B.A. J., Mar. 1985, at 78. Antitrust plaintiffs with weak claims (but not those with strong ones) are advised to add RICO claims. See Fricano \& Brusca, RICO Route May Suit Potential Antitrust Plaintiffs, Legal Times, Apr. 8, 1985, at 17, col. 1.

165. Sedima, S.P.R.L. v. Imrex Co., 741 F.2d 482 (2d Cir. 1984), rev'd, 105 S. Ct. 3275 (1985).

166. See Barr v. WU1/TAS, Inc., 66 F.R.D. 109 (S.D.N.Y. 1975). But see Schacht v. Brown, 711 F.2d 1343 (7th Cir.), cert. denied, 464 U.S. 1002 (1983); see also Note, Civil RICO: The Temptation and Impropriety of Judicial Restriction, 95 Harv. L. Rev. 1101 , 1106-09 (1982) (disapproving requirement of organized crime link).

167. See Bankers Trust Co. v. Rhoades, 741 F.2d 511 (2d Cir. 1984), vacated, 105 S. Ct. 3550 (1985).

168. See United States v. Computer Sciences Corp., 689 F.2d 1181, 1190-91 (4th Cir. 1982), cert. denied, 459 U.S. 1105 (1983). But see United States v. Hartley, 678 F.2d 961, 987-90 (1 lth Cir. 1982), cert. denied, 459 U.S. 1170 (1983); see also Haroco, lnc. v. American Nat'l Bank \& Trust Co., 747 F.2d 384, 401 (7th Cir. 1984) ("Discussion of this person/enterprise problem under RICO can casily slip into a metaplyysical or ontological style of discoursc-after all, when is the person truly an entity 'distinct' or 'scparate' from the enterprise?"), aff'd on other grounds, $105 \mathrm{~S}$. Ct. 3291 (1985).

169. Sec Scdima, S.P.R.L. v. Imrcx Co., 105 S. Ct. 3275 (1985) (rcjecting requircment of conviction for predicate acts); Amcrican Nat'l Bank \& 'Trust Co. v. Haroco, lnc., l05 S. Ct. 3291 (1985) (civil claim under RICO necd not allege damages suffered 
so that some opportunities for dismissal have disappeared, although others may arise. ${ }^{170}$

The experience under RICO illustrates how limits imposed by the substantive law can frustrate efforts to facilitate dismissal of cases. Despite the intensity of the lower courts' attempts to locate grounds for dismissal, the Supreme Court has suggested that the RICO boom can only be curtailed by amending the statute. ${ }^{171}$ Similar substantive constraints may hamper efforts to develop grounds for dismissal in other areas as well. Whatever the pressures of the litigation boom, then, often the substantive law simply will not support development of the kind of separable issues that can be used to winnow cases at the pleading stages.

Where the substantive law does provide such separable issues, it will often be necessary, in response to the natural urge towards vagueness in pleading under the Federal Rules, ${ }^{172}$ for a court to demand additional particulars to resolve such separable issues. This emphasis on detail differs significantly from the notice pleading idea because it seeks to elicit details that will allow resolution of the case at the outset. ${ }^{179}$ But the existence of such a severable issue does not mean that making an early decision will always be easy. Consider, for example, pleadings dispositions on statute of limitations grounds. Although it is an affirmative defense, limitations can be raised by motion to dismiss, and the plaintiff can be required to provide details sufficient to evaluate the limitations question. Despite the seemingly automatic application of limitations, however, the law has over time developed equitable doctrines regnlating accrual and tolling that turn on the facts of the particular case and therefore often preclude pretrial decision. ${ }^{174}$ Even where a severable issue can be identified, a reliable merits decision at the outset may be impossible.

2. Pleadings Determinations that Defendant Has Not Violated the Plaintiff's Rights. - Even without segregating a separable issue a court may, with sufficient details, be able to decide at the pleading stage that the de-

through violation of predicate offenses). While acknowledging that plaintiffs must allege each element of a RICO claim, the Court, by a 5-4 vote, held that the Second Circuit's efforts to construct new elements for a claim were invalid. Sedima, $105 \mathrm{~S}$. Ct. at 3286. The majority recognized that the dramatic growth in civil RICO cases may not be what Congress had in mind, but said that if correction is necessary it should come from Congress. Id. at 3287.

170. In Sedima, the Court clearly enunciated four requirements that must be alleged to state a claim: "(1) conduct (2) of an enterprise (3) through a pattern (4) of racketeering activity." $105 \mathrm{~S}$. Ct. at 3285 (footnote omitted). It remains to be seen how the lower courts will apply these elements, particularly the third and fourth, at the pleading stage.

171. See supra note 169 .

I72. See supra notes 74-76 and accompanying text.

173. See supra note 124 and accompanying text (discussing use of motions for a more definite statement to accomplish this purpose).

174. Sec Marcus, Fraudulent Concealment in Federal Court: Toward a Morc Disparate Standard?, 71 Geo. L.J. 829, 902-04 (1983). 
fendant has not violated the plaintiff's rights. For example, in 1976 the Supreme Court upheld dismissal of a prisoner suit alleging that defendants' denial of medical care constituted cruel and unusual punishment. ${ }^{175}$ Although it reaffirmed the policy that pro se complaints should be liberally construed, ${ }^{176}$ the Court rejected this prisoner's claim because his "complaint provide[d] a detailed factual accounting of the treatment he received. . . . It is apparent from his complaint that he received extensive medical care and that the doctors were not indifferent to his needs." 177

Such case-specific decisions are possible in a number of contexts, and the courts' rejection of conclusory allegations often reflects the sensible belief that more detail may reveal a basis for dismissal. Civil rights cases provide a good example; it is commonplace now for courts to hold that conclusory allegations are insufficient to state a claim. ${ }^{178}$ This is no mere formality. The tendency of litigants to repackage anything that strikes them as unfair as a violation of due process compels the courts to demand more information about the historical events that the plaintiff claims occurred. Often these details demonstrate that the incident constituted at most a state law tort, and dismissal follows. ${ }^{179}$

Merits determinations of this type are not limited to civil rights cases. The willingness of many courts to find that the facts as pleaded reveal no legal violation reflects an approach to dispositions on the merits at the pleading stage that Conley $v$. Gibson would not appear to permit. In Car Carriers, Inc. v. Ford Motor Co. ${ }^{180}$ for example, the Seventh Circuit expressly rejected a literal application of the Conley stan-

175. Estelle v. Gamble, 429 U.S. 97 (1976).

176. Id. at 106 (citing Haines v. Kerner, 404 U.S. 519 (1972)).

177. Id. at 108 n.16. For a similar dismissal of a prisoner case, see Benson v. Cady, 761 F.2d 335 (7th Cir. 1985).

178. See, e.g., Williams v. Gorton, 529 F.2d 668, 671 (9th Cir. 1976) (Conclusory allegations, unsupported by facts, are insufficient to state a claim under the Civil Rights Act.).

179. See, e.g., Rodgers v. Lincoln Towing Serv., 771 F.2d 194 (7th Cir. 1985) (delay in booking suspect due to negligence not a valid civil rights claim); Wright v. Anthony, 733 F.2d 575, 577 (8th Cir. 1984) (no constitutional violation where plaintiff was allowed to submit only written statement to congressional committee rather than full oral statement); Woodard v. Los Fresnos Indep. School Dist., 732 F.2d 1243 (5th Cir. 1984) (departure from school rnles regarding punishment at most a tort, not a violation of constitutional rights); Green v. Maraio, 722 F.2d 1013 (2d Cir. 1983) (prisoner's action against state court judge dismissed because judge did not act with clear absence of jurisdiction and was therefore immune).

These cases should be distinguished from other civil rights actions dismissed by the courts for lack of state action, e.g., Cohen v. lllinois Inst. of Technology, 58 I F.2d 658 (7th Cir. 1978) (conclusory allegation that state and federal support to private school constituted support for specific discriminatory practices insufficient), cert. denied, 439 U.S. 1135 (1979), which fits the mold discussed supra notes 149-74 and accompanying text, of severable elements for which specifics may be demanded.

180. 745 F.2d 1101 (7th Cir. 1984), cert. denied, 105 S. Ct. I758 (1985). 
dard in upholding the dismissal of an antitrust complaint. ${ }^{181}$ Plaintiffs had provided car transportation services to Ford Motor Company for a number of years until Ford terminated the arrangement and contracted with another company for those services. Plaintiffs sued Ford and the new transport company, alleging that defendants had entered into a conspiracy to drive plaintiffs out of business, switched the contract to provide transport services through a "sham and knowingly predatory bid," and thereby enabled the competitor to acquire plaintiffs' assets for less than their true value. ${ }^{182}$ The trial court granted defendants' motion to dismiss. ${ }^{183}$

The Seventh Circuit affirmed, reasoning that "Conley has never been interpreted literally" 184 and that, in practice, "a complaint . . . must contain either direct or inferential allegations respecting all the material elements necessary to sustain a recovery under some viable legal theory." "185 Measured against this standard, the court found the specific factual allegations to contradict, rather than support, any viable theory for plaintiffs. To prevail, plaintiffs had to allege either a per se violation of the antitrust laws or a forbidden effect on competition. Although plaintiffs used the per se label, ${ }^{186}$ they had not alleged that defendants had terminated plaintiffs' services as retaliation for price cutting, which is traditionally handled as a per se violation. To the contrary, plaintiffs alleged that they had continually sought to raise their prices. ${ }^{187}$ Further, even if their allegations of a conspiracy were credited as showing a group boycott, that would constitute a per se violation only if used to implement agreements that themselves constituted per se violations, which the complaint failed to show. ${ }^{188}$ The ominous reference to "sham" and "predatory" behavior, the court concluded, stated no more than a legal conclusion: "it would be improper for us to attempt to conjure up some sort of tenable antitrust scheme for these cryptic allusions." 189 Plaintiffs' effort to allege an anticompetitive impact similarly failed: "In considering a motion to dismiss, the court is not required to don blinders and to ignore commercial reality."190 Hence, plaintiffs' assertions about "predatory" actions meant nothing, the court found, because it would be "preposterous" for Ford

181. 1d. at 1106.

182. Id. at 1105 .

183. 561 F. Supp. 885,889 (N.D. 1ll. 1983).

184. 745 F.2d at 1106 (citation omitted).

185. 1d. (quoting in re Plywood Antitrust Litig., 655 F.2d 627, 641 (5th Cir. 1981)).

186. ld. at 1108.

187. $1 \mathrm{~d}$.

188. 1d. at 1109 .

189. Id. at 1109 n.5; see also id. at 1107 n.4 ("Standing alone, the boilerplate recitation of a conspiracy in . . the complaint is insufficient to withstand a motion to dismiss.").

190. Id. at 1110 . 
to arrange to be the victim of such activity. ${ }^{191}$ To uphold this complaint, the court concluded, would undercut the Sherman Act by undermining a buyer's right to replace its supplier. ${ }^{192}$

Car Carriers strains the outer limits of pleading practice. Although courts can sometimes make such determinations on the basis of detailed pleadings, ${ }^{193}$ it will not often be possible to do so. Certainly, insistence on detailed pleading should not be used to obscure unsettled issues of substantive law, ${ }^{194}$ and using pleadings as an opportunity to evaluate the whole of the plaintiff's allegations may tempt courts to question the factual conclusions on which the plaintiff has rested his claim, ${ }^{195}$ a temptation that courts should resist.

191. Id. The court at two points discounted plaintiffs' allegations as "inherently implausible." See id. at 1107 n.4, 1109 . Although this language suggests that it was evaluating the persuasiveness of plaintiffs' evidence, a highly questionable course, see infra notes 196-227 and accompanying text, it should be considered as part of its reference to commercial reality. See supra text accompanying note 190 .

192. $745 \mathrm{~F} .2 \mathrm{~d}$ at 1110 .

193. See, e.g., Sante Fe Indus. v. Green, 430 U.S. 462, 474 (1977) (affirming dismissal of securities claim because "the transaction, if carried out as alleged in the complaint, was neither deceptive nor manipulative").

194. This seems to be the objection of Professor Roberts in his article on the application of fact pleading to standing cases. See Roberts, supra note 12, at 421-25. But the root problem there is substantive; as Professor Chayes has observed, the Supreme Court has a ritual recitation of the "rules" goveruing standing and, " $[t]$ his ritual recitation having been performed, the Court then chooses up sides and decides the case." Chayes, The Supreme Court 1981 Term-Foreword: Public Law Litigation and the Burger Court, 96 Harv. L. Rev. 4, 23 (1982). As Professor Roberts argues, the Court may be using pleading language to hide its failure to reach consensus on the law of standing. See Roberts, supra note 12, at 421 . Were there such a consensus, however, it might be that standing questions could often be resolved on the pleadings with sufficient particulars, although Professor Roberts remains dubious owing to the ambiguity of substantive standing doctrine. See id. at 430 . If so, standing is like many other substantive legal rules that can only be applied with reference to a multitude of factors and are therefore not readily subject to application at the pleading stage. See supra notes 145-48 and accompanying text. But cf. Page, The Scope of Liability for Antitrust Violations, 37 Stan. L. Rev. 1445, 1448 (1985) (arguing that antitrust standing rules are well suited to summary disposition).

195. One way they might do this is by mischaracterizing essentially factual conclusions as legal conclusions. For example, in Strauss v. City of Chicago, 760 F.2d 765 (7th Cir. 1985), the plaintiff alleged an unprovoked beating by a police officer for which he claimed the city was liable due to its practice of hiring and retaining brutal police officers. In support of his allegation that the city had such a practice, he submitted statistical summaries of complaints filed about police behavior. Although it claimed to follow Conley, id. at 767-68, the Seventh Circuit affirmed dismissal because it found the statistical material too general, id. at $768 \& \mathrm{n} .4$, a circumstance it held "renders the allegations mere legal conclusions of Section 1983 liability devoid of any well-pleaded facts," id. at 767. Compare Payne v. City of LaSalle, I Fed. R. Serv. 3d (Callaghan) 11 16, 1117 (N.D. III. 1985) (suggesting Strauss creates a Catch-22 situation for the $\S 1983$ plaintiff suing a municipality). 


\section{The Problem of Factual Conclusions Contrasted}

The thrust of many of the new fact pleading cases is to challenge the plaintiff's "conclusory" factual allegations, often about the defendant's state of mind. Car Carriers could be criticized as doing so, but it focuses on the legality of defendants' conduct as alleged rather than plaintiffs' inability to marshall enough evidence to support their factual conclusions.

The line between scrutiny of legal conclusions and scrutiny of factual conclusions is often obscure, however. For example, in Decker $v$. Massey-Ferguson, Ltd., ${ }^{196}$ plaintiff sued on behalf of a class of purchasers of Massey-Ferguson stock, charging that the company, a producer of farm machinery, had committed securities fraud by painting too rosy a picture of itself in its 1975 annual report and other documents. After ordering plaintiff to amend his complaint to identify the specific statements claimed to be false, the district court dismissed. ${ }^{197}$

Citing the Supreme Court's warnings about strike suits in Blue Chip Stamps, ${ }^{198}$ the Second Circuit affirmed. It did so by comparing the allegations in plaintiff's "prolix and discursive 69 page complaint"1 199 with the 1975 annual report and other documents issued by Massey. On the basis of this comparison, it found plaintiff's allegation that Massey had falsely claimed record profits "patently false" because the reports were "replete with facts and figures whose accuracy has not been challenged" that showed just such profits. ${ }^{200}$ Similarly, it rejected plaintiff's claim that Massey should have announced that it was undercapitalized because its capitalization and debt structure were fully disclosed in its financial reports. ${ }^{201}$ it also held that Massey's 10-K filings with the SEC "substantially satisfied" then-applicable regulations, and that any forecasts contained in the report were not actionable. ${ }^{202}$

Decker seems to further the objectives of the substantive law because it reflects the court's conviction that defendants had not violated the law. Hence, Decker might be viewed, at least in part, as a legal conclusion case. In particular, the court's conclusions that Massey's 10-K filings satisfied applicable regulations and that forecasts are not actionable appear to mandate dismissal. But the handling of other claims is troubling. Undoubtedly, "patently false" charges should not enable a plaintiff to use broad discovery to bludgeon a nuisance settlement out of defendants. But where the focus is on factual conclusions, one loses

196. 681 F.2d 111 (2d Cir. 1982).

197. Decker v. Massey-Ferguson, Ltd., 534 F. Supp. 873, 884 (S.D.N.Y. 1981), aff'd, 681 F.2d 111 (1982).

198. Blue Chip Stamps v. Manor Drug Stores, 421 U.S. 723, 740 (1975); sce supra notes 58-60 and accompanying text.

199. 681 F.2d at 114 .

200. Id. at 115 .

201. 1d. at 116 .

202. 1d. at 116-17. 
the confidence, present in a legal conclusion case, that a decision to dismiss on the merits is sufficiently reliable.

Decker illustrates the point even though plaintiff's claim there seems to have been extremely weak. Although the court was able to cite "facts and figures whose accuracy has not been challenged," there is at least a nagging doubt about whether plaintiff could have challenged those figures had he been allowed discovery. ${ }^{203}$ Moreover, the appellate court seemed to be relying on material that was not contained in the complaint, ${ }^{204}$ which would normally convert the motion to dismiss into a motion for summary judgment. ${ }^{205}$ lndeed, evaluation of certain securities law claims may inherently be unworkable on the pleadings. ${ }^{206}$ ln Decker, the court might well have concluded that plaintiffs should be afforded little or no discovery before ruling on summary judgment, ${ }^{207}$ but handling the motion in the summary judgment format better accords with the objective of assuring that the outcome accurately reflects the substantive merits.

The difficulties with scrutinizing factual conclusions become manifest in connection with the frequent demand that the plaintiff proffer sufficient supporting evidence to make conclusory allegations, particu-

203. See Note, supra note 12 , at 1437 (criticizing Decker for denying plaintiff discovery of internal memoranda and projections).

204. For example, the court cited a New York Times story about John Deere \& Co., another manufacturer of agricultural implements, to support its conclusion that the period after 1975 was "the type of economic climate in which section 10(b) litigation flourishes." $681 \mathrm{~F} .2 \mathrm{~d}$ at 114. The court stated that Massey's 1975 annual report was "in the record," but it did not say that the document was an exhibit to plaintiff's complaint, although its citation to pertinent authority under Fed. R. Civ. P. 10(c) suggests it may have been. See 681 F.2d at 113 (citing 5 C. Wright \& A. Miller, supra note 3, § 1327, at 491 n.18). In any event, the court appeared to look beyond the 1975 annual report and referred to Massey's consolidated financial statements, SEC filings, and 1977 annual report. See id. at 117.

205. See Fed. R. Civ. P. 12(b).

206. The Decker court's approach seems quite different from the attitude in Goldman v. Belden, 754 F.2d 1059 (2d Cir. 1985), in which the court reversed dismissal of a securities class action, stating:

The court's view that the facts may not really have been problems was not so much a ruling as to the adequacy of the pleading as it was an evaluation of the materiality of the nondisclosures. Materiality is a mixed question of law and fact, and a complaint may not properly be dismissed pursuant to Rule 12(b)(6) (or even pursuant to Rule 56) on the ground that the alleged misstatements or omissions are not material unless they are so obviously unimportant to a reasonable investor that reasonable minds could not differ on the question of their importance.

Id. at 1067 (citation omitted); see also Eichler v. Berner, 105 S. Ct. 2622, 2629 n.21 (1985) ("We note . . . the inappropriateness of resolving the question of the respondents' fault solely on the basis of the allegations set forth in the complaint."). Although there may be a distinction between determining whether a statement is "false" and whether it is "material," any such distinction seems insufficient to support such a difference in treatment.

207. See infra notes $317-29$ and accompanying text. 
larly those relating to state of mind, 208 credible. In these cases, unlike Decker, the court is not affirmatively concluding that plaintiff's charges are false, but only that they are unsupported. Although the desire to insist on some underlying evidence is natural, that exercise is materially different from the substantive scrutiny described above. Requiring plaintiff to proffer supporting evidence at the pleadings stage cannot be justified for several reasons.

First, this attack on factual conclusions stands the code distinction between ultimate facts and evidence on its head. State of mind is undoubtedly a fact, even now sometimes labelled an "ultimate fact."200 The insistence on more details is really a demand for an offer of proof-some specification of evidence that will raise an inference that the defendant's state of mind was as alleged. This creation of a new burden of production effects a subtle but real shift in the substantive law because plaintiff's lack of evidence provides insufficient assurance that plaintiff in fact has no valid claim against defendant. ${ }^{210}$

Where the court requires detailed support for a legal conclusion, analysis of the details may permit the court to conclude confidently that the plaintiff has no case. ${ }^{211}$ But where the plaintiff is unable to provide details because only the defendant possesses such information, no such confidence is possible. ${ }^{212}$ To the contrary, it may be that the defendant has so effectively concealed his wrongdoing that the plaintiff can unearth it only with discovery. To insist on details as a prerequisite to discovery is putting the cart before the horse. RICO provides an illustration. Rather than requiring that the defendant be convicted of the offenses that the plaintiff relied upon as predicate acts, ${ }^{213}$ some courts insisted that, where defendant had not been convicted, plaintiff plead sufficient facts to provide probable cause to believe that defendant was guilty of the predicate offenses.214 The Seventh Circuit, however, properly refused to impose this pleading requirement because plaintiffs have no opportunity for discovery before filing suit. ${ }^{215}$

208. See supra notes $90-93,96$ and accompanying text.

209. See Herbert v. Lando, 441 U.S. 153, 170 (1979) (defendant's actual malice an "ultimate fact" in defamation cases); see also Bose Corp. v. Consumers Union of United States, Inc., 466 U.S. 485, 498 (1984) (knowledge a "fact").

210. Cf. Hazard, The Effect of the Class Action Device Upon the Substantive Law, 58 F.R.D. 307,307 (1973) ("[I]t seems fair to say that procedure's very function is to modify the substantive law."). But see supra note 144 .

211. See supra notes $175-95$ and accompanying text.

212. See Note, supra note 12 , at 1435 ("[T] he inflexible application of the particularity requirement in contemporary securities fraud cases inevitably results in the dismissal of some meritorious claims.").

213. See supra note 165 and accompanying text.

2I4. See Taylor v. Bear Stearns \& Co., 572 F. Supp. 667, 682-83 (N.D. Ga. 1983); Bache Halsey Stuart Shields Inc. v. Tracy Collins Bank \& Trust Co., 558 F. Supp. 1042, 1045-46 (D. Utah 1983).

215. See Haroco, Inc. v. American Nat'l Bank \& Trust Co., 747 F.2d 384, 404 (7th Cir. 1984), aff'd on other grounds, 105 S. Ct. 3291 (1985). 
Second, insistence on detailed evidence regarding state of mind violates the second sentence of Rule 9(b), which specifies that "[m]alice, intent, knowledge, and other condition of mind of a person may be averred generally." 216 On its face, this sentence precludes use of the Rule to require plaintiffs to provide particulars on the very matters for which so many courts say that supporting facts are now required. ${ }^{217}$

Third, the new scrutiny of the proof regarding factual conclusions calls for judgments for which the legal system presently lacks an appropriate standard. How much evidence is enough? Consider Ross v. A.H. Robins $C_{0},{ }^{218}$ where the Second Circuit held that plaintiff in a securities fraud action had failed to allege sufficient facts to support the conclusion that defendants knew by 1973 of the dangers of the Dalkon Shield. ${ }^{219}$ Plaintiffs had provided some detail by pointing out that in 1972 an independent researcher had identified and reported on the risks of the device and that in May, 1974, Robins itself had sent a letter to 120,000 doctors alerting them to possible health problems resulting from use of the device. The appellate court held that this showing was insufficient without some connection between the independent researcher and Robins. ${ }^{220}$

The court's insistence on more evidence is difficult to understand. Even if there were no connection between the researcher and Robins, the fact that the researcher could independently assemble data on the harmful effects of the device by 1972 certainly supports the inference that Robins could readily have done so itself or at least have learned of the independent report. Indeed, other cases have shown that Robins made a practice of gathering data on the safety of the Dalkon Shield. ${ }^{221}$ It had earlier made a number of public statements, presumably based on the investigations of skilled persons, about the safety of the prod-

216. Fed. R. Civ. P. 9(b); see Wayne Inv., lnc. v. Gulf Oil Corp., 739 F.2d 11, 13 (1st Cir. 1984) (Rule 9(b) does not require particulars from which intent can be inferred) (citation omitted).

217. See supra notes $90-93$ and accompanying text.

218. 607 F.2d 545 (2d Cir. 1979), cert. denied, 446 U.S. 946 (1980).

219. See supra notes $91-93$ and accompanying text.

220. See 607 F.2d at 558 .

221. For a detailed review of the efforts actually made by Robins to evaluate the safety of this new product, see the post-trial findings of fact in Hawkinson v. A.H. Robins Co., 595 F. Supp. 1290, 1295-1306 (D. Colo. 1984). The Hawkinson court found further that "Robins could have learned about and warned of such dangers with the application of the reasonable skill and foresight expected of an established pharmaceutical company," and that "Robins not only failed to disclose its lack of knowledge; it affirmatively asserted that the Shield was safe." Id. at 1307. This is not to suggest that the outcome of this personal injury case should affect the decision of a securities fraud suit, given the different culpability showing required in a securities fraud action, but only to show that the need for more detailed allegations to get into discovery in Ross is difficult to square with the results of discovery in other cases. 
uct. ${ }^{222}$ By May, 1974, it was sufficiently alarmed about safety to write over one hundred thousand doctors. The court of appeals felt, however, that any inference of knowledge was not a "strong" inference. ${ }^{22 y}$ Whatever this standard requires, it is not defined anywhere in the Federal Rules.

Fourth, this analysis invites weighing of evidence. It is traditionally said that the likelihood of plaintiff's success on the factual merits is not a proper subject for evaluation at the pleading stage. ${ }^{224}$ Yet the courts do weigh the likelihood that plaintiff will be able to prove its factual conclusions. In a recent civil rights suit, for example, the Ninth Circuit affirmed dismissal because the "factual surroundings" cut against the plaintiff's conclusion of racial motivation. ${ }^{225}$ Such a determination at the pleading stage is highly troubling. The better view was articulated by the Seventh Circuit in refusing to impose a probable cause standard in RICO suits: "Even the most specific allegations do not establish probable cause unless they are reliable. We are, to say the least, perplexed as to how a court might undertake such evaluations of reliability in deciding a motion to dismiss under Rule 12."226 To suggest that courts can do so stands in stark contrast to the standard for grant of summary judgment, where any reasonable inference favoring the party opposing summary judgment is said to create an issue of fact precluding pretrial disposition. ${ }^{227}$

In sum, the courts' tendency to scrutinize the proof supporting

222. See S. Englemayer \& R. Wagman, Lord's Justice 39-54 (1985) (detailing statcments made by Robins, and contrasting them to evidence available to Robins). Indeed, Robins even used information from Mary Gabrielson, upon whose report the plaintiff in Ross relied, see 607 F.2d at 558, in publicity designed to assuage doubts about the safety of the Dalkon Shield. See S. Englemayer \& R. Wagman, supra, at 48-50.

223. Ross, 607 F.2d at 558. Lest it be thought that the judges of the Second Circuit can easily apply this kind of demanding standard, consider Albany Welfare Rights Org. Day Care Center, Inc. v. Schreck, 463 F.2d 620 (2d Cir. 1972), cert. denied, 410 U.S. 944 (1973). Plaintiff claimed that defendant county officials refused to refer children to its child care facilities in retaliation for plaintiff's organizing activities among welfare recipients. The majority upheld dismissal because "[ $t$ ]he complaint in the instant action presents no facts to support the allegation that the refusal to refer children was in retaliation for [plaintiff's] organizing activities." Id. at 623. Judge Feinberg, dissenting, agreed that dismissal would be appropriate if the complaint "offered nothing more than [a] bald assertion," id. at 624 , but found that "the complaint is the antitlesis of the typically sparse, bare bones, conclusory pleading that might justify dismissal," id. at 625.

224. See, c.g., Leimer v. State Mut. Life Assurance Co., 108 F.2d 302, 306 (8th Cir. 1940) ("No matter how improbable it may be that [plaintiff] can prove her claim, she is entitled to an opportunity to make the attempt . . . .").

225. Jones v. Community Redevelopment Agency, 733 F.2d 646, 650 (9th Cir. 1984). But cf. Wade v. Johnson Controls, Inc., 693 F.2d 19, 22 (2d Cir. 1982) (allegation that employer failed to replace or repair defective air purification system with purpose of harming employees "not beyond the realm of possibility").

226. Haroco, Inc. v. American Nat'l Bank \& Trust Co., 747 F.2d 384, 404 (7th Cir. I984), aff'd on other grounds, 105 S. Ct. 3291 (1985).

227. See I0A C. Wright, A. Miller \& M. Kane, Federal Practice \& Procedure $\$ 2728$, at 178-86 (1983) (although convinced that should verdict be returned against movant at 
factual conclusions appears impossible to justify within the existing framework for pleadings decisions. As the following discussion demonstrates, the risks associated with heightened scrutiny of factual conclusions are not warranted even when limited to "suspicious" claims nor are they permissible as part of the trial court's discretion.

\section{Segregating Suspicious Claims-Toward DisCRETIONARY Dismissals?}

Since the new fact pleading cases seem to be limited to certain recurring situations symptomatic of the perceived drawbacks of the litigation boom, the new fact pleading might be cabined to a few limited categories of cases. A review of the likely categories shows, however, that none provides an adequate justification for applying stringent pleading requirements. The alternative of expanded trial court discretion to dismiss also fails. The problems of the litigation boom cannot so easily be shunted onto a special track.

\section{A. Disfavored Claims}

The classic justification for singling out some claims for onerous pleading requirements is that they are "disfavored."228 Malicious prosecution, for example, has long been viewed with disfavor because of its tendency to cause litigation to proliferate-making one lawsuit the basis for filing a second lawsuit.229 The critical point is that the disfavor is directed at the type of claim being asserted, not the risk that it may prove baseless. Federal courts adopting stricter scrutiny of factual conclusions often display somewhat similar disfavor for claims falling into the categories that have experienced the greatest increase in filings during the last twenty years. But the growth in filings provides insufficient justification for this treatment. ${ }^{230}$

The most common focus for disapproval are civil rights cases, but such claims should not be disfavored. To the contrary, they are central to our concept of liberty, and the Supreme Court has repeatedly emphasized their importance. ${ }^{231}$ Private enforcement has played a key

trial court would have to set aside verdict and order new trial, court has no discretion to grant summary judgment if there is dispute as to facts).

228. See 5 C. Wright \& A. Miller, supra note $3, \S 1296$, at 400 (disfavored claim idea an "old cliche").

229. See Prosser \& Keeton, supra note 52, at 876.

230. Cf. Dalton, Taking the Right to Appeal (More or Less) Seriously, 95 Yale L.J. 62,64 (1985) (caseload concerns alone provide insufficient justification for curtailing right to appeal); Redish, Book Review, 85 Colum. L. Rev. 1378, 1391 (1985) (increase in civil rights filings not a reason for limiting liberal interpretation of civil rights laws).

231. See, e.g., Bounds v. Smith, 430 U.S. 817, 828 (1977) ("the first line of defense against constitutional violations"). Thus, when Congress authorized the award of attorneys' fees to the prevailing party in civil rights litigation, the Court held that prevailing plaintiffs could recover almost automatically, see Newman v. Piggie Park Enters., 390 U.S. 400 (1968) (per curiam), but that defendants could only recover if the action werc 
role in accomplishing civil rights goals, ${ }^{232}$ so that antagonism toward assertion of this type of claim by private litigants cannot be justified.

Securities claims, the next most vilified category, are hardly disfavored. Many of the most important claims were implied by the courts themselves in order to accomplish the objectives of legislation that might not be enforced without private suits. ${ }^{233}$ Although the Supreme Court has cut back on implication of private remedies, it has also rejected efforts to impose a high burden of proof in actions under rule 10b-5, ${ }^{234}$ the most significant group of securities actions. Whatever their potential for abuse, securities fraud suits are not disfavored claims.

Similarly, although overbroad reading of the Sherman Act in favor of plaintiffs may frustrate its purposes, ${ }^{235}$ antitrust claims cannot be viewed as disfavored. Private antitrust suits were intended by Congress to serve an important function in deterring violation of the Sherman Act. ${ }^{236}$

A variant of the disfavored claims approach is the argument that the potential for harming a person's reputation that fraud claims present justifies heightened scrutiny in those cases. ${ }^{237}$ Similar arguments have been advanced concerning claims under RICO (involving charges that defendant is a "racketeer"), but it is difficult to say that the opprobrium connected with such claims is really greater than that attached to

brought vexatiously or in bad faith, see Christianburg Garment Co. v. EEOC, 434 U.S. 412 (1978). Marek v. Chesny, 105 S. Ct. 3012 (1985), alters the former result where the defendant makes a Rule 68 offer to compromise that plaintiff refuses, and plaintiff recovers less than the amount of the Rule 68 offer.

232. See, e.g., Brown v. Board of Educ., 347 U.S. 483 (1954); see also Norman, The Strange Career of the Civil Rights Division's Commitment to Brown, 93 Yale L.J. 983, 984 (1984) (After Brown, the federal government did little to enforce it, leaving enforcement to private suits.).

233. See, e.g., J.I. Case Co. v. Borak, 377 U.S. 426, 432 (1964) (action implied for violation of rules governing proxy solicitation because "[p]rivate enforcement of the proxy rules provides a necessary supplement to [Securties \& Exchange] Commission action").

234. See Herman \& MacLean v. Huddleston, 459 U.S. 375 (1983), in which the Court refused to apply the common law requirement that fraud be proved by clear and convincing evidence in a private action under Rule 10b-5 because "an important purpose of the federal securities statutes was to rectify perceived deficiencies in the available common-law protections by establishing higher standards of conduct in the securities industry." Id. at 389; cf. Eichler v. Berner, 105 S. Ct. 2622, 2628-29 (1985) (Court refuses to apply common law in pari delicto defense in federal securities fraud action).

235. Thus, the Antitrust Division of the Department of Justice has recently participated on behalf of defendants in antitrust cases, arguing against broad interpretations of antitrust law. See Marcus, Conflicts Among Circuits and Transfers Within the Federal Judicial System, 93 Yale L.J. 677, 707-08 n.187 (1984).

236. See, e.g., Bruce's Juices, Inc. v. American Can Co., 330 U.S. 743, 751-52 (1947); Javelin Corp. v. Uniroyal, Inc., 546 F.2d 276, 280 (9th Cir. 1976), cert. denicd, 431 U.S. 938 (1977).

237. See supra note 89 and accompanying text. 
others which do not invoke heightened pleading scrutiny.238 Accordingly, this basis for treating claims as disfavored seems unpersuasive as well.

It would surely be odd to treat the above claims as less favored than ordinary automobile torts that find their way into federal court due to diversity jurisdiction. Yet auto accident cases are clearly, under Form 9 , subject to minimal scrutiny at the pleading stage. The factors that may give civil rights, securities, or antitrust claims a high settlement value despite lack of merit result from problems endemic to the litigation system-such as broad discovery-and the fact that the content of the underlying substantive laws provide no easy handles for early resolution of claims. These difficulties, however, provide no basis for treating these claims as disfavored.

\section{B. Disfavored Litigants}

If the nature of the claim does not justify a hostile reception in the courts, it may be argued that the identity of the plaintiff or his lawyer does. But the categories suggested by the cases do not commend themselves as general standards. To the contrary, a review of these categories suggests that one should not single out cases for stricter pleading scrutiny by focusing on the characteristics of the participants.

1. The Repeat Player. - Although Professor Marc Galanter may be correct that most private parties are "one shot litigants," 239 some individuals distinguish themselves by suing frequently. ${ }^{240}$ The sheer

238. Judge Cardamone made this point well in his dissent in Sedima, S.P.R.L. v. Imrex Co., 741 F.2d 482 (2d Cir. 1984) (Cardamone, J., dissenting), rev'd, 105 S. Ct. 3275 (1985):

Today, defendants in civil suits are labelled as violators of environmental laws when pumping coal byproducts into the atmosphere, despoilers of our rivers when emptying oil from their tanker's bilges, adulterers in state divorce actions, and killers in vehicular wrongful death actions. The allegations of the civil complaint do not make these citizens criminals, although their conduct may well subject them to criminal prosecutions. Why the outcry over RlCO?

ld. at 508. In reversing, the Supreme Court appeared to agree with him. See $105 \mathrm{~S}$. Ct. at 3283 ("As for stigma, a civil RICO proceeding leaves no greater stain than do a number of other civil proceedings."); see also Herman \& McLean v. Huddleston, 459 U.S. 375, 390 (1983) ("The interests of defendants in a securities case do not differ qualitatively from the interests of defendants sued for violations of other federal statutes such as the antitrust or civil rights laws ....").

239. See Galanter, Why the "Haves" Come Out Ahead: Speculations on the Limits of Legal Change, 9 Law \& Soc'y Rev. 95, 97-114 (1974) (differentiating between litigants who are "one shotters" who have only occasional recourse to the courts, and "repeat players," who are involved in many similar litigations over time).

240. This is hardly a new phenomenon. Consider, for example, the following description of the "serious litigant" in 16th century England: "The serious litigant . . . . litigated as a matter of business practice, less with the intention of vindicating his rights than to obtain advantage over his opponent, bent upon bringing the adversary party to compromise or ultimately wearing him down to defeat and capitulation." Barnes, Star Chamber Litigants and Their Counsel, 1596-1641, in Legal Records and the Historian 
weight of past litigation sometimes prompts courts to curtail new filings by certain plaintiffs, particularly in prisoner suits, ${ }^{241}$ and a history of vexatious litigation is considered pertinent to sanctions for present abuse of litigation. 242 Given the concerns about the litigation boom, one might argue that courts should ask more of the repeat plaintiff at the pleading stage.

The fact that the plaintiff is a repeat litigant does not, standing alone, warrant stricter treatment. Consider, for example, Harry Lewis, perhaps America's leading corporate gadfly. Without attracting much public attention, Mr. Lewis, who often files derivative suits, has over the last decade brought literally dozens of suits, including at least one that reached the Supreme Court. ${ }^{243}$ He has not won all the cases, but he has occasionally obtained relief. While some judges have been suspicious about his litigation activities, ${ }^{244}$ it seems that in general he has not been found to have engaged in groundless litigation.245 Even though derivative actions may be viewed as peculiarly susceptible to abuse, ${ }^{246}$ the fact that a given plaintiff has filed many such actions does not necessarily show that he is abusing the litigation process.

There are two basic and related problems with subjecting the pleadings of repeat litigants to stricter scrutiny. First, the only possible relevance of a plaintiff's prior litigation activities is to show that he is

7, 22-23 (J. Baker ed. 1978). For recent examples see Franklin v. Murphy, 745 F.2d 1221,1231 n.13 (9th Cir. 1984) (plaintiff had filed over 100 separate actions); Demos v. Kincheloe, 563 F. Supp. 30 (E.D. Wash. 1982) (184 actions in three years).

241. See, e.g., Abdullah v. Gatto, 773 F.2d 487 (2d Cir. 1985) (leave of court needed for future filings); Urban v. United Nations, 768 F.2d 1497 (D.C. Cir. 1985) (injunction against filing suit in any federal court without prior approval of that court). Regarding the burden of prisoner suits, see infra note 269 .

242. See, e.g., Taylor v. Prudential-Bache Sec., Inc., 39 Fed. R. Serv. 2d (Callaghan) 1309 (N.D.N.Y. 1984) (Imposing Rule 11 sanctions on plaintiff said to "embody the paragon of harassing and vexatious litigation" on the basis of " $[t]$ he beleaguering saga of these and other Alan Taylor lawsuits.").

243. See Transamerica Mortgage Advisors, Inc. v. Lewis, 444 U.S. 11 (1979). Also, a leading corporate decision is the product of a Lewis lawsuit. See Aronson v. Lewis, 473 A.2d 805 (Del. 1984).

This author's research revealed that by the end of 1984, Mr. Lewis had been a named plaintiff in 43 reported federal cases, filed in seven different circuits, as wcll as eight reported state cases. The data are on file with the Columbia Law Revicw.

244. See Lewis v. Curtis, 671 F.2d 779, 782-83 (3d Cir. 1982), in which the district judge, before dismissing, queried Lewis" lawyer: "So you brought another strike suit, didn't you?" The appellate court reversed and ordered that another judge handle the case on remand. See id. at 789.

245. Professor Conard singles out Lewis v. Anderson, 615 F.2d 778 ( 9 th Cir. 1979), cert. denied, 449 U.S. 869 (1980), as an example of a sensible decision to terminate a derivative suit after the challenged action was ratified by shareholders and the shareholders' right to be consulted had thereby been vindicated. Conard, supra note 66 , at
$274-75$.

246. See, e.g., Brown v. Hart, Schaffner \& Marx, 96 F.R.D. 64, 67 (N.1). 1ll. 1982) ("Such lawsuits are the base work of rapacious jackals whose declared concern for cor"porate well-being camouflages their unwholesome appetite for corporate dollars."). 
the type of person who indulges in groundless litigation, supporting the inference that this litigation is also groundless. This is precisely the sort of relevance reasoning that is forbidden by the general prohibition against introduction of character evidence. ${ }^{247}$ Courts usually exclude evidence of prior litigation activity, in particular, as unduly prejudicial because dislike for the litigious is not a proper ground for deciding the merits of the current case. ${ }^{248}$

The second problem stems from the first. The inference regarding the litigant's character is only supportable if the past litigation was in fact groundless; the fact that plaintiff is a gadfly is not relevant to the merits of the current case. Accordingly, the court must determine whether the prior litigation was indeed groundless. Since one would presumably make such an inference only if there were several earlier cases, ${ }^{249}$ that determination could require more effort than deciding the instant case on its merits, a point that is reinforced by considering the difficulty of evaluating Mr. Lewis' past litigation. ${ }^{250}$ Partly to avoid such collateral issues, even where character evidence is allowed it is normally restricted to opinion or reputation evidence, rather than evidence of specific events. ${ }^{251}$

Inviting though it seems, then, the repeat player criterion is neither a useful nor a fair device for singling out cases for heightened scrutiny at the pleading stage. Even if it were, it would apply in a very small number of cases. If litigation abuse is confined to that small number of cases it is not so significant as many argue.

247. See Fed. R. Evid. 404(a) (excluding evidence of character to prove action in conformity therewith on a particular occasion).

248. See C. McCormick, McCormick on Evidence $\S 196$ (E. Cleary 3d ed. 1984); 1 D. Louisell \& C. Mueller, Federal Evidence $\$ 99$ (I977); cf. Crisafi v. Holland, 655 F.2d 1305,1309 (D.C. Cir. 1981) ("[A] complaint filed in forma pauperis is not subject to dismissal simply because the plaintiff is litigious. The number of complaints a poor person files does not alone justify peremptory dismissal.").

When prior claims are admitted in evidence, it is generally on the theory that they are so similar and numerous that they cast a shadow on the truthfulness of the present claim. For example, San Antonio Traction Co. v. Cox, 184 S.W. 722 (Tex. Civ. App. 1916), a suit for injuries allegedly sustained alighting from one of defendant's streetcars, involved 15 other claims by relatives of plaintiff for injuries allegedly received during the same year getting onto or off of defendant's streetcars. The court excluded the evidence because plaintiff had not been linked to the claims by his relatives, but stated that it would have allowed them had plaintiff himself made them. See also Mintz v. Premier Cab Ass'n, 127 F.2d 744 (D.C. Cir. 1942) (evidence admitted that plaintiff had previously made claim for injuries allegedly received while a passenger in a cab).

249. See D. Louisell \& C. Mueller, supra note 248 , § 99, at 735-36 (impeachment of claimant with evidence of "many recent, unsuccessful, similar claims" permissible but not where there is only "a single unsuccessful previous claim, even if it was highly similar").

250. See supra notes $243-45$ and accompanying text.

25l. See Fed. R. Evid. 405. 
2. The Disfavored Lawyer. - While most litigants are not repeat players, lawyers certainly are, ${ }^{252}$ and their prior litigation activities could affect the courts' attitudes toward their cases. Some courts have relied on such personal history in making important decisions. ${ }^{253}$ While courts have not explicitly based the dismissal of a pleading on a lawyer's history in prior litigation, this does not dispel the real experience of lawyers that judges view different lawyers differently. Nonetheless, for two important reasons challenges to the plaintiff's lawyer do not provide an appropriate basis-overt or covert-for stricter scrutiny of the pleadings.

First, there will be disputes about the lawyer's prior behavior. For example, consider I. Walton Bader, the attorney for plaintiff in Heart Disease Research Foundation v. General Motors Corp. ${ }^{254} \mathrm{Mr}$. Bader has had a number of clashes with judges during his career, ${ }^{255}$ and has recently been sanctioned by a judge who relied in part on this history. ${ }^{256}$ One could imagine that defendants might be tempted to attack Mr. Bader as part of an effort to have cases dismissed. The example of Mr. Bader, however, proves just how inappropriate a lawyer's prior behavior would be as a basis for dismissal. As will always be the case, there is another side: some view Mr. Bader as a vigorous, effective advocate. ${ }^{257}$ More

252. See Coffee, supra note 137 , at 18-19, 22-23 (referring to plaintiff's attorncys as repeat players and describing a "distinct subspecies" who are said to repeatedly file strike suits).

253. See, e.g., Eavenson, Auchmuty \& Greenwald v. Holtzman, 775 F.2d 535, 543 (3d Cir. 1985) (in imposing sanctions, district court referred to "a lot of harrassment" that lawyer had used in another case); Rogers v. Kroger Co., 669 F.2d 317, 319 (5th Cir. 1982) (district court dismissed action when plaintiff's attorney was unprepared to proceed, citing a prior case in which she had also been unprepared). It should be noted that the district court orders in both these cases were reversed.

254. 463 F.2d 98 (2d Cir. 1972); see supra notes 13-19 and accompanying text. Recall that the district court dismissed the suit as frivolous. See 15 Fed. R. Serv. 2d (Callaghan) 1517, 1519 (S.D.N.Y. 1972).

255. See In re Corrugated Container Antitrust Litig., 659 F.2d 1332, 1335 (5th Cir. 1981) (reporting lower court's finding that Bader had tried to disrupt multidistrict proceedings "by filing and threatening to file duplicative and harassing litigation"); Independent Investor Protective League v. Touche Ross \& Co., 607 F.2d 530, 534 n.5 (2d Cir.) (affirming discovery sanctions against Bader and characterizing his conduct as "utterly intolerable and reprehensible"), cert. denied, 439 U.S. 895 (1978); Slumbertogs, Inc. v. Jiggs, Inc., 353 F.2d 720, 720 (2d Cir. 1965) (affirming sanction of dismissal as appropriate "[i]n view of the dilatory and contumacious conduct of plaintiffs and their counsel in virtual defiance of the rules and orders of at least six judges in the district court"), cert. denied, 383 U.S. 969 (1969); Jackson v. Bader, 74 A.D.2d 621, 622, 424 N.Y.S.2d 926, 927 (1980) (listing examples of "I. Walton Bader's cavalier attitude towards the spirit and letter of the CPLR").

256. See In re Itel Sec. Litig., 596 F. Supp. 226, 235 (N.D. Cal. 1984) (referring to "Mr. Bader's history in this type of litigation"). For more background on this case, sec Riley \& Galante, Mr. Outside-A Fiasco Over Fees, Nat'l L.J., Nov. 19, 1984, at 1, col. 1.

257. See A Bondholder's Best Friend, Forbes, Dec. 15, 1975, at 41, 43 ("13ader's career reminds us of a story about Davy Crockett. As he travelled through Tennessec, a stranger asked why he was going to Texas, where he later fell at the Alamo. "To fight for 
generally, disputes about the lawyer's pedigree could, like examination of plaintiff's prior litigation, ${ }^{258}$ immerse the court in the merits of other lawsuits, hardly a helpful addition to burdensome motion proceedings. ${ }^{259}$

Second, even assuming that a lawyer's prior bad behavior can be established in some cases, it is perilous to ascribe that prior behavior to his current client, and it is that client's case that is subject to dismissal. ${ }^{260}$ However true it may be that the client is generally derivatively responsible for the lawyer's actions on his behalf,261 it hardly follows that the client is responsible for the lawyer's misdeeds in other cases.

3. The Poor. - The Federal Rules were designed, in part, to open up the federal courts to those of lesser means, and their moderate success in this regard may have caused courts to tighten pleading requirements for the poorest plaintiffs, indigents. Some courts fear such litigants because indigents seem to have nothing to lose by bringing groundless suits. ${ }^{262}$ Moreover, they often sue pro se, so that insistence on details may be more likely to reveal a fatal defect than in other cases, where a lawyer alert to the defect might try to elude detection through vagueness. The actual fate of most suits brought by the indigent-victories for plaintiffs are extremely rare ${ }^{263}$ - seems to justify suspicions that a particular indigent plaintiff cannot prove facts that merit relief.

Courts animated by such suspicions arguably have a statutory basis for treating pauper cases differently. The same statute that authorizes

my rights,' said Crockett."); The Numbers Game, Forbes, Apr. 1, 1974, at 54, 54 ("Walton Bader is the scourge of the U.S. accounting profession. A man whose name strikes fear in the hearts of senior partners in the big certified public accounting firms.").

258. See supra notes $249-51$ and accompanying text.

259. Cf. Becker, The Judge's Perspective, 51 Antitrust L.J. 437, 439 (1983) ("Now we will have Rule 11 hearings, and then we will have discovery on the Rule 11 issue. If you want to proliferate litigation, if you want to cause further delay, pass these rules because we will have sanctions hearings coming out of our ears . . . ."). But cf. Fed. R. Civ. P. 11 advisory committee note (Rule 11 discovery should only be conducted in "extraordinary circumstances" and a hearing may not be necessary).

260. Thus, when Rule 11 was amended in 1983 to put more teeth into sanctions against attorneys who abuse litigation, the amendment also deleted the provision authorizing the striking of the pleading. As the advisory committee notes explained, the power to strike "tended to confuse the issue of attorney honesty with the merits of the action." Fed. R. Civ. P. 11 advisory committee note. Cf. Risinger, Honesty in Pleading and Its Enforcement: Some "Striking" Problems with Federal Rule of Civil Procedure 1 1, 61 Minn. L. Rev. 1 (1976) (criticizing use of former Rule 11 to dismiss cases).

261. See Link v. Wabash R.R., 370 U.S. 626, 633-34 (1962) ("Petitioner voluntarily chose this attorney as his representative in the action, and he cannot now avoid the consequences of the acts or omissions of this freely selected agent.").

262. See, c.g., Franklin v. Murphy, 745 F.2d 1221, 1226 (9th Cir. 1984); Anderson v. Coughlin, 700 F.2d 37, 42 (2d Cir. 1982).

263. Prisoner suits, which constitute the bulk of pro se filings, result in judgment for the defendant in a very high proportion of the cases. A 1978 study reported that more than two-thirds of these suits are dismissed as groundless by the court without any response from defendant, and that only a very small number go to trial. Sce Turner, supra note 132 , at 617-18. 
waiver of filing fees in in forma pauperis cases also provides that the court may dismiss the complaint "if satisfied that the action is frivolous or malicious."264 Some courts feel that this power should not be exercised in any case that would survive a motion to dismiss under Conley $v$. Gibson, ${ }^{265}$ but others view the statute as allowing greater latitude in dismissing the action. ${ }^{266}$ The Supreme Court itself has clamped down on in forma pauperis petitions for certiorari, ${ }^{267}$ perhaps giving tacit support to the proponents of the more stringent treatment.

Carefully scrutinizing the factual conclusions alleged by the indigent is nevertheless hard to justify, as well as contrary to the objectives of the Federal Rules. The Supreme Court has repeatedly emphasized the need to take a liberal view of pro se pleadings, ${ }^{208}$ and the indigent are likely to be least able to ferret out the sort of proof the courts demand to support factual conclusions without first having some discovery. Moreover, despite widespread fear that courts will be inundated with such cases, their actual impact seems modest. ${ }^{269}$ Pleading practice

264. 28 U.S.C. $\$ 1915$ (d) (1982). The statute has so provided since it was enacted in 1892. Act of July 20, 1892, ch. 209, 27 Stat. 252. On the difficulty of defining frivolous, see Comment, Courts Are No Place for Fun and Frivolity: A Warning to Vexatious Litigants and Over-Zealous Attorneys, 20 Willamette L.J. 441, 446-48 (1984).

265. See e.g., Phillips v. Mashburn, 746 F.2d 782, 784 (1 lth Gir. 1984); Brandon v. District of Columbia Bd. of Parole, 734 F.2d 56, 59 (D.C. Cir. 1984); see also Turner, supra note 132, at 649 (arguing that courts should, at a minimum, use Conley v. Gibson standard).

266. See Franklin v. Murphy, 745 F.2d 1221, 1228 (9th Cir. 1984) (court can dismiss as frivolous although complaint states a claim if it is based on "wholly fanciful" factual allegations); Anderson v. Coughlin, 700 F.2d 37, 43 (2d Cir. 1983); cf. Spears v. McCotter, 766 F.2d 179 (5th Cir. 1985) (court may assign case to magistrate for evidentiary hearing to probe conclusory allegations and determine if case frivolous); Watson v. Ault, 525 F.2d 886 (5th Gir. 1976) (court may require plaintiff to respond to questionnaire to assist it in deciding if claim frivolous).

There does not appear to be historical support for broader dismissal under the statute than would be allowed had the plaintiff paid the fees, and very few cases were decided prior to the adoption of the Federal Rules in 1938. See O'Connell v. Mason, 127 F. 435,437 (D. Mass. 1903) ("It is possible that extreme cases might arise, where, looking only at the face of the declaration, the court might determine that the suit was frivolous or malicious even though the declaration were not demurrable."), affd, $132 \mathrm{~F}$. 245 (1st Cir. 1904).

267. See, e.g., Brown v. Herald Co., 464 U.S. 928 (1983) (denying motion for leave to proceed in forma pauperis). Four Justices dissented because review of such motions increases the Court's workload. See id. at 929-30 (Brennan, J., dissenting).

268. See, e.g., Boag v. MacDougall, 454 U.S. 364, 365 (1982); Hughes v. Rowe, 449 U.S. 5, 9 (1980). These cases follow Haines v. Kerner, 404 U.S. 519, 520 (1972), which stated that pro se complaints are subjected to "less stringent standards than formal pleadings drafted by lawyers."

269. See Eisenberg, Section 1983: Doctrinal Foundations and an Empirical Study, 67 Cornell L. Rev. 482, 526-33 (1982) (civil rights cases, including prisoner cases, iınpose modest burden); Turner, supra note 132, at 637-38, 647-49 (discussing expedited procedures used to process prisoner petitions); see also C. Seron, The Roles of Magistrates in Federal District Courts 44 (1983) (prisoner cases often assigned to magistrates). But cf. Ford v. Estelle, 740 F.2d 374 (5th Cir. 1984) (prisoncr cases cannot be 
in these cases may be more likely to elicit fatal details, but it is unlikely to provide a method for assessing factual conclusions. Like the repeat player, the poor plaintiff should not be shunted onto another track. ${ }^{270}$

\section{The Strike Suit Scenario}

Rather than focusing on the type of claim or identity of the plaintiff, a court could seek to isolate those cases that might be strike suits. Certainly the Supreme Court's opinion in Blue Chip Stamps v. Manor Drug Stores ${ }^{271}$ supports sensitivity to the risk of strike suits, and the concern over strike suits lies close to the heart of the malaise of the liberal ethos. ${ }^{272}$

The problem is identifying a strike suit. ${ }^{273}$ One feature often associated with strike suits is that the burden of litigation is sufficient to prompt the defendant to settle, despite the weakness of the plaintiff's claim, in order to avoid litigation expense or other disagreeable side effects of litigation, such as publicity or interference with an impending transaction. This concern is, of course, a reason for promoting pretrial decisions. ${ }^{274}$ It is of doubtful utility in singling out cases for stricter pleading treatment, however, because there is no intrinsic relation between litigation expense or other disagreeable side effects of a lawsuit and the absence of merit in plaintiff's case. Litigation expense, for example, results from the need to do extensive preparation for trial, and may make a small claim that is assured of success on the merits into a nuisance suit, that is, one where litigation costs outweigh expected recovery. ${ }^{275}$ Similarly, the fact that the suit may delay a transaction provides no basis for dismissing the suit if the proposed transaction itself is

assigned to magistrates for trial without parties' consent). Moreover, the assertion of groundless claims may not be cost free for the petitioner. See Tasby v. United States, 504 F.2d 332 (8th Cir. 1974) (prosecution for perjury in connection with prisoner petition).

270. Except for in forma pauperis situations, there is normally no occasion for plaintiffs to disclose their financial condition to the court. Even if there were, there is no standard by which to decide who is sufficiently poor for this unfavorable treatment.

271. 421 U.S. 723 (1975); see supra notes 58-60 and accompanying text.

272. Such concerns surface in decisions to limit discovery. See, e.g., Aviation Specialties, Inc. v. United Technologies Corp., 568 F.2d 1186, 1190 (5th Cir. 1978) (describing plaintiff's interrogatories as "nothing more than a thinly veiled attempt to enhance the strike capability of its suit"). Defendants can play this game also. See Blake Constr. Co. v. International Harvester Co., 521 F. Supp. 1268, 1270 (N.D. Ill. 1981) (referring to "Stalingrad defense").

273. See Pennsylvania Gas \& Water Co. v. Federal Power Comm'n, 427 F.2d 568, 576 (D.C. Cir. 1970) ("Much that is sound and prophylactic in corporate law was developed in so-called strike suits . . . ."); W. Cary \& M. Eisenberg, Cases and Materials on Corporations 888 (5th ed. 1980) ("The strike suit . . . may very well be no more than an over-the-hill dragon, puffed into life to frighten the courts away from deciding substantive issues.").

274. Sce supra notes $134-42$ and accompanying text.

275. See Rosenberg \& Shavell, supra note 141, at 4 . 
illegal. Moreover, there is no standard by which litigation inconvenience is to be gauged; every defendant finds litigation burdensome.

The key factor, then, is the weakness of the claim. Where the focus is on a factual conclusion, however, the court is without a reliable way of identifying cases in which plaintiffs are likely to prevail. ${ }^{276}$ On balance, the strike suit scenario simply authorizes judges to dismiss cases they view as weak when it appears to them that the litigation will unduly inconvenience the defendant. ${ }^{277}$

\section{Discretionary Dismissals}

The problems with the strike suit scenario suggest another approach-granting judges discretion to dismiss suits they conclude are suspicious. The classic approach is that trial judges have no discretion; any dismissal for failure to state a claim is subject to full review, and the trial judge's decision is accorded no deference whatsoever.278 Perhaps this rule should be relaxed, and an abuse of discretion standard of review substituted. 279 This approach might allow judges to consider a variety of factors including those discussed above, and to impose stricter pleading standards when a case fits an abusive litigation profile.

Such a change in pleading doctrine would be consistent with the current trend across a spectrum of trial administration issues. The Federal Rules of Evidence, for example, largely rely on the exercise of sensible discretion by the trial court in admitting or excluding evidence. ${ }^{280}$ The case management movement, fueled by the 1983 amendments to the Federal Rules of Civil Procedure, similarly emphasizes the importance of discretionary decisions on such matters as timing and scope of

276. See supra notes 196-227 and accompanying text.

277. It may even invite unwanted and irrelevant speculation about plaintif's motives. For example, in Grant v. Smith, 574 F.2d 252 (5th Cir. 1978), the district court dismissed a housing discrimination action after a trial to the court without a jury, noting that plaintiffs seemed more interested in a strike suit than in securing accomodations. Id. at 255. The appellate court reversed because of the district court's emphasis on plaintiffs' good faith, which it found irrelevant to the question whether there was forbidden discrimination. Id.

278. See, e.g., Kelson v. City of Springfield, 767 F.2d 651, 653 (9th Cir. 1985).

279. The classic analysis of this standard is Rosenberg, Judicial Discretion of the Trial Court, Viewed From Above, 22 Syracuse L. Rev. 635 (1971). For a careful examination of the types of treatment that an appellate court can adopt for discretionary trial court decisions, broadly characterized as delegation and deference, see Post, The Management of Speech: Discretion and Rights, 1984 Sup. Ct. Rev. 169, 208-19.

Interestingly, early advocates of notice pleading seemingly viewed discretion as an antidote to the tendency of appellate courts of that era to invent new pleading nicetics under the Codes. Thus, Professor Whittier, writing in 1918 to urge adoption of noticc pleading, expressed "hope[1 that no law would develop determining what is sulficient notice of any cause of action or defense. It should be left a question of fact in each casc to be determined by the trial judge . . ." Whitticr, supra note 111 , at 505 .

280. See Waltz, Evidence is Dead, Wigmore Obsolescent: Long Live Judicial Discretion!, 65 Chi. B. Rec. 284 (1984). 
discovery, which can have a very great impact on a party's ability to prepare and present his case. ${ }^{281}$ Perhaps most analogous is the handling of the demand on directors requirement for derivative actions under Rule 23.1-also governed by an abuse of discretion standard. ${ }^{282}$

Expanded trial court discretion may indeed be the emerging reality of trial court handling of pleadings motions. In Heart Disease Research Foundation v. General Motors Corp. ${ }^{283}$ for example, the Second Circuit said the trial court had discretion to dismiss conclusory claims of conspiracy. ${ }^{284}$ More significantly, trial judges are sometimes allowed to direct plaintiffs to replead even though the case would not be subject to dismissal, and to enforce this order by dismissing if the plaintiff does not comply. ${ }^{285}$ Other cases suggest that appellate courts are coming to regard the handling of pleadings motions as such individualized matters that consistency among decisions, the hallmark of an issue of law, is not critical. Thus, in a 1978 decision affirming the dismissal of a securities fraud shareholders' class action, the Second Circuit was unmoved by the fact that the same plaintiff, represented by the same lawyer, had been allowed to proceed with another complaint of virtually identical specificity. Instead, it disdained any effort to reconcile a welter of dismissal cases: "We see no profit in attempting to analyze these decisions, which may or may not be consistent and each of which necessarily rests on its particular facts." 286 With their emphasis on early "issue definition" and early disposition of groundless claims and defenses, the 1983 amendments are likely to accelerate this trend toward discretion. ${ }^{287}$

281. See supra notes 61-62 and accompanying text. But consider Friendly, Indiscretion About Discretion, 31 Emory L.J. 747, 755 (1982): "If we have been moving increasingly in the direction of seeking justice in the individual case by more general rules and grants of dispensing power . . . restrictions upon review of such decisions made by courts of first instance are increasingly unacceptable."

282. See Lewis v. Graves, 701 F.2d 245, 248 (2d Cir. 1983).

283. 463 F.2d 98 (2d Cir. I972).

284. See supra note 16 and accompanying text.

285. For a recent example, see Friedlander v. Nims, 755 F.2d 810 (11th Cir. 1985), a class action alleging RICO and securities fraud claims. One defendant moved to dismiss, and the trial court dismissed with leave to amend on the ground that the complaint failed to plead fraud with particularity as required by Rule 9(b). When plaintiff did not amend, the trial court dismissed with prejudice. The appellate court affirmed the dismissal as a sanction, but carefully noted that it was not holding that the original complaint was subject to dismissal without leave to amend. See id. at 814 n.6. However logical this treatment is, it raises the prospect that a trial court could establish a predicate for dismissal with prejudice by ordering plaintiff to provide more specifics to support a claim not subject to dismissal with prejudice as originally pleaded.

286. Denny v. Barber, 576 F.2d 465, 470 (2d Cir. 1978). The other case is Denny v. Carey, 72 F.R.D. 574 (E.D. Pa. 1976).

287. Precisely this possibility has engendered much concern among commentators. Sce, e.g., Sherman, Book Review, 63 Tex. L. Rev. 721, 729-32 (1984). Nonetheless, there is some suggestion that even substantive decisions may be subject to trial court discretion under RICO. See Bankers Trust Co. v. Rhoades, 741 F.2d 511, 518 n.7 (2d 
Although some relaxation of the idea that trial judges have no discretion in connection with pleading decisions may be inevitable, discretion is no panacea for handling the kind of factual conclusions that have created the problem. First, increased discretion in this area runs squarely against the grain of the Federal Rules. It is one thing to argue for expanded power to resolve pleadings matters in order to assure litigants an opportunity for a decision on the merits. It is quite another to authorize a judge to decide cases on instinct. ${ }^{288}$ That is not what we mean when we endorse a merits decision.

Second, giving increased discretion to judges would disregard the very real attitudinal differences among judges. With the growth of case management, there can be little doubt that individual differences among judges make the assignment of the case very important to the way it develops in the pretrial stage, but differences in attitude toward such matters as timing and breadth of discovery do not threaten the substantive law. It is hard to deny, however, that at least some judges view certain types of claims, although they are provided for under law, as unimportant; ${ }^{289}$ to increase discretion to dismiss could lead to judge-by-judge "disfavored claims" treatment, surely less desirable than the disfavored claim theory discussed above. ${ }^{290}$ Such action would threaten to fragment the substantive law by permitting judges to create their own requirements for various kinds of claims. Present practice already makes such diversity unavoidable to some extent. To illustrate, one district judge has suggested that it is practical for litigants in RICO cases to tailor their allegations to the known predilections of the judge to whom the case is assigned. ${ }^{291}$ Although that

Cir. 1984) ("The matter of whether given conduct should be considered one or more than one 'predicate act' is a matter best left, in the first instance, to the discretion of the district judge."), vacated, 105 S. Ct. 3550 (1985); cf. Willamette Sav. \& Loan v. Blake \& Neal Fin. Co., 577 F. Supp. 1415, 1430 (D. Or. 1984) (regarding supposed requirement of an independent racketeering injury, court observes that "[c]ourts recognize a racketeering injury when they see it," citing Justice Stewart's observation about obscenity that "1 know it when 1 see it"); Waste Recovery Corp. v. Mahler, 566 F. Supp. 1466, 1468 (S.D.N.Y. 1983) (same).

288. Cf. Resnik, supra note 44 , at $840-41$ (discussing outrage caused by judge's decision based on a coin flip).

289. Recall, for example, the hearings on the nomination of G. Harrold Carswell to the Supreme Court, in which it was reported that as a district judge he had regularly dismissed civil rights actions and been reversed. See $11 \mathrm{R}$. Mersky \& J. Jacobstein. The Supreme Court of the United States: Hearings and Reports on Successful and Unsuccessful Nominations of Supreme Court Justices by the Senate Judiciary Committee, 1916-1972, at 117-23 (1975) (testimony of Gary Orfield); id. at 139-47 (testimony of John Lowenthal); id. at 177-82 (testimony of Norman Knopf); id. at 22 1-33 (testimony of Leroy Clark); id. at 282-93 (testimony of Joseph Rauh). In particular, Prolessor Orfield pointed up one case as an "example of [Judge Carswell's] willingness to use his discretion as a district judge to even strike out [an] argument on a very important issttc raised by the litigants." Id. at I 19.

290. See supra notes $228-38$ and accompanying text.

291. Speech by Milton Shadur before the Illinois Institute on Continuing legal lid- 
suggestion results in part from the present diversity of interpretations of RICO, it also shows how individualized "justice" could become if greater discretion to dismiss on the pleadings were to become accepted practice.

Third, there is simply no reason to believe that a trial judge is well equipped for this task, whether experienced or not. One supposed hallmark of a discretionary decision is that the trial judge is better positioned to decide the matter than appellate judges looking at a cold record.292 That is simply not true in a meaningful way with respect to factual conclusions in pleadings. At the pleading stage, the judge has had no exposure to the parties or to evidentiary material. Instead, he has only seen the pleadings and dealt with the lawyers. On the basis of this information, it is impossible for him to form reliable conclusions about whether given defendants have conspired to violate the antitrust laws, discriminated against the plaintiff on grounds of race, or failed to make a full disclosure in connection with the purchase or sale of securities. Yet these are precisely the types of issues that trial judges are resolving using the vehicle of fact pleadings. ${ }^{293}$ Admittedly judges must make a similar determination at the summary judgment stage, but that decision is at least based on evidentiary material. ${ }^{294}$ At the pleading stage the judge must guess whether the plaintiff, if allowed discovery, will be able to gather evidence to support his claims. Uninformed judicial speculation is not an adequate means of arriving at correct decisions on the merits.

Finally, enhancing the importance of selection of the judge would encourage judge shopping. There can be no doubt that there are already incentives for judge shopping and that our courts seek to prevent it.295 To endorse merits decisions that reflect the individual preferences of the judges involved, however, would tend to undermine the notion that parties can expect evenhanded, and roughly equal, justice from any judge. ${ }^{296}$ However doubtful that assumption may be in real-

ucation (Jan. 30, 1985) (unpublished) (on file at the offices of the Columbia Law Review):

Once the case is assigned, ... both lawyers should immediately run the judge's name and the RICO acronym on Lexis or Westlaw. . . . Once you've taken that judicial research step, unless the judge is such a maverick that you have to play your case for the Court of Appeals from the beginning, it is obviously judicious on your part to adapt to what our sponsors [of the program] . . . call the "judicial perspective."

292. See Rosenberg, supra note 279 , at $663-65$.

293. See supra notes $84-104$ and accompanying text.

294. Fed. R. Civ. P. 56(e) requires that affidavits submitted on summary judgment motions be made on personal knowledge and set forth facts admissible in evidence. For a discussion of the alternative of summary judgment treatment, see infra notes 297-342 and accompanying text.

295. See Marcus, supra note 235, at 706-07 n.183.

296. Cf. In re Cement Antitrust Litig., 673 F.2d 1020, 1027 (9th Cir. 1982) ("[I]t is difficult for us to think of a question which is more separable from and collateral to the 
ity, it could not be sustained were judges explicitly authorized to indulge their prejudices on the merits. Such a system would overtly tie the outcome of the case to the assignment, and one could only hypocritically contend that efforts to influence the assignment of the case are improper.

Accordingly, the solution to the problem of litigation abuse does not lie in the direction of increasing the discretion of the trial judges to dismiss cases because they sense misuse of the litigation system. Such a development could undermine the substantive law just as fully as failure to dismiss meritless suits.

\section{The Summary Judgment Route}

The fact that a case is not dismissed does not mean that it can only be resolved on the merits by a full dress trial. To the contrary, the intermediate step of summary judgment exists precisely to enable courts to examine the factual conclusions of the pleader and determine whether they are supported by sufficient evidence to warrant the time and effort of a trial. Moreover, summary judgment works both ways; plaintiffs can also use it to obtain a merits disposition. Indeed, summary judgment was originally adopted in England to enable plaintiffs to penetrate groundless defenses. ${ }^{297}$ Summary judgment was the stage that Clark himself hoped would flourish as the mechanism for pretrial disposition of cases, ${ }^{298}$ but the early experience under Rule 56 failed to achieve Clark's desire. Clark's own Second Circuit, over his objections, adopted a "slightest doubt" standard, which resembled the dismissal standard later articulated in Conley $v$. Gibson: summary judgment should be denied whenever there is the slightest doubt about the entitlement of the moving party to judgment. 299 Moreover, in I962 the Supreme Court cautioned that summary judgment should be "used sparingly in complex antitrust litigation where motive and intent play leading

merits" than recusal of one judge.), affd sub nom. Arizona v. Ash Grove Cement Co., 459 U.S. 1190 (1983); Hampton v. City of Chicago, 643 F.2d 478, 479 (7th Cir. 1981) ("While plaintiffs have a right to have their claim heard by the district court, they have no protectable interest in the continued exercise of jurisdiction by a particular judge.").

297. Louis, Federal Summary Judgment Doctrine: A Critical Analysis, 83 Yale L.J. 745,745 (1974).

298. Smith, supra note 3 , at $918-19,929$.

299. See, e.g., Arnstein v. Porter, 154 F.2d 464, 468 (2d Cir. 1946); Dochler Metal Furniture Co. v. United States, 149 F.2d 130, 135 (2d Cir. 1945). See generally Louis, supra note 297 , at 760-62 (concluding that slightest doubt standard made summary judgment unavailable on facts where moving party would be entitled to a directed verdict). This standard has been labelled "plainly wrong." Sonenshein, State of Mind and Credibility in the Summary Judgment Context: A Better Approach, 78 Nw. U.L. Rev. 774,798 (1983). For a discussion of Clark's opposition to this standard, see Smith. supra note 3, at 930-31. For a discussion of the contrasting views of Judge Jerome Frank, the architect of the slightest doubt standard, see R. Glennon, The lconoclast as Reformer 156-57 (1958). 
roles." 300

Limitations on summary judgment were particularly troublesome in the kinds of cases that came to typify the new litigation boom precisely because those cases were often complex and turned on issues of motive and intent. ${ }^{301}$ Hence, restrictions on summary judgment may have acted as a catalyst for the reemergence of fact pleading. Certainly, the Second Circuit's refusal to credit plaintiffs' allegations that defendants were or should have been aware of the dangers of the Dalkon Shield in Ross v. A.H. Robins Co. ${ }^{302}$ shows that the "slightest doubt" standard was not being employed in the pleading context. The juxtaposition of these developments was ironic: at the pleading stage, plaintiffs might be denied discovery altogether unless they could offer facts giving rise to a "strong inference" 303 supporting their factual conclusions; thereafter, plaintiffs who had access to discovery were indulged with great laxity at the summary judgment stage under the slightest doubt view. This seems backwards.

The tendency toward this ironic result has abated over recent years as limitations on summary judgment have relaxed. ${ }^{304}$ In 1968, the Supreme Court signalled greater flexibility in the handling of summary judgment in antitrust cases, ${ }^{305}$ and circuit courts have since upheld

300. Poller v. Columbia Broadcasting Sys., 368 U.S. 464, 473 (1962).

301 . See supra text following note 105 .

302. 607 F.2d 545 (2d Cir. 1979), cert. denied, 446 U.S. 946 (1980); see supra notes $91-93$ and accompanying text.

303. See supra notes $93,219-23$ and accompanying text.

304. For examples, see infra notes 305-307 and accompanying text. See generally Louis, Summary Judgment and the Actual Malice Controversy in Constitutional Defamation Cases, 57 S. Cal. L. Rev. 707, 709-10, 715 n.49 (1984) (discussing shift away from Poller $v$. CBS and absence of articulated new rules); Sonenshein, supra note 299, at 778-79 (1963 amendment to Rule 56 expanded availability of summary judgment); Booker, Summary Judgment Proves Versatile Antitrust Tool, Legal Times, Feb. 14, 1983 , at 17, col. 1 (growing availability of summary judgment in antitrust cases). For a strategy for such decisions see Schwarzer, Summary Judgment Under the Federal Rules: Defining Genuine Issues of Material Fact, 99 F.R.D. 465 (1984).

This is not to say that trial judges now have a free hand to grant summary judgment. See Wechsler v. Steinberg, 733 F.2d 1054, 1058-59 (2d Cir. 1984) (reversing summary judgment for defendant accountants in securities fraud action because "[i]ssues of motive and intent are usually inappropriate for disposition on summary judgment"); Neubauer, Snyder \& Nolan, Judges Compare Courts, 11 Litig., Spring 1985, at 10, 15 (district judge explains that "[w]bat with the track record that district judges have in this circuit on the subject of summary judgment . . . . [granting summary judgment] is a high-risk judicial decision, as we all know"). But cf. Schwarzer, supra, at 467 \& n.9 (reporting that in fact summary judgments are reversed less frequently than most judgments in Ninth Circuit).

305. See First Nat'l Bank v. Cities Serv. Co., 391 U.S. 253, 288-90 (1968). Tle Court upheld summary judgment in favor of defendant in an antitrust case, adding:

While we recognize the importance of preserving litigants' rights to a trial on their claims, we are not prepared to extend those rights to the point of requiring that anyone who files an antitrust complaint setting forth a valid cause of 
summary judgment on the issue of whether there was a conspiracy. ${ }^{306}$ The Supreme Court has gone further in civil rights cases and encouraged summary disposition of suits against government officials on the defense of qualified immunity, ${ }^{307}$ an issue that turns in part on state of mind. ${ }^{308}$

Rather than indulging all possible doubts in favor of the opponent to summary judgment, the courts seem to be shifting emphasis toward ensuring an adequate opportunity for discovery and then scrutinizing the fruits of that discovery. But the defendant can move for summary judgment at any time, and may do so at the beginning of the case in conjunction with a motion to dismiss. ${ }^{309}$ At that point, the plaintiff is in no better position to oppose summary judgment than he is to include detailed evidence in the complaint in response to stringent fact pleading requirements. The plaintiff can, however, request under Rule 56(f) that the summary judgment motion be postponed while he obtains discovery necessary to rebut the defendant's showing. ${ }^{310}$ The focus should shift, then, to application of Rule 56(f).

A plaintiff is not automatically entitled to a Rule $56(f)$ postponement. Plaintiff must show that by exercising reasonable diligence he could not have previously obtained evidence to controvert the defendant's showing. ${ }^{311}$ Although this requirement may often be easy for the

action be entitled to a full-dress trial notwithstanding the absence of any significant probative evidence tending to support the complaint.

Id. at 290. In dissent, Justice Black argued that the decision could not be squared with Poller $v$. CBS. Id. at 303-05.

306. See, e.g., Barnes v. Arden Mayfair, Inc., 759 F.2d 676 (9th Cir. 1985); Products Liab. Ins. Agency, Inc. v. Crum \& Forster Ins. Cos., 682 F.2d 660 (7th Cir. 1982); Parsons v. Ford Motor Co., 669 F.2d 308 (5th Cir.), cert. denied, 459 U.S. 832 (1982). Cf. Matsushita Elec. Indus. v. Zenith Radio Corp., 54 U.S.L.W. 4319, 4322-25 (U.S. Mar. 26, I985) (where defendants lacked rational economic motive to conspire, defendants entitled to summary judgement unless plaintiffs show unambiguous evidence that tends to exclude the possibility that defendants acted independently).

307. See Harlow v. Fitzgerald, 457 U.S. 800, 813-19 (1982).

308. Interestingly, the Court's method for promoting summary disposition was to introduce an objective reasonable person standard in place of a subjective standard looking to defendant's actual state of mind. See Mitchell v. Forsyth, 105 S. Ct. 2806, 2810-11 (1985); Harlow v. Fitzgerald, 457 U.S. 800, 818 (1982). For criticism of this approach, see Note, Qualified Immunity for Government Officials: The Problem of Unconstitutional Purpose in Civil Rights Litigation, 95 Yale L.J. 126 (1985).

309. In fact, if on a motion to dismiss the pleadings, the defendant submits and the court does not exclude matters outside the plaintiff's pleading, the court must convert the motion to one for summary judgment. See Fed. R. Civ. P. 12(b).

310. See Fed. R. Civ. P. 56(f):

Should it appear from the affidavits of a party opposing the motion that he cannot for reasons stated present by affidavit facts essential to justify his opposition, the court may refuse the application for judgment or may order a continuance to permit ... depositions to be taken or discovery to bc had . . . .

311. See, e.g., Pfeil v. Rogers, 757 F.2d 850, 857 (7th Cir. 1985) (upholding rejection of Rule 56(f) request because plaintiffs' claim they could not earlier have obtained information "strain[ed] credibilty"). 
plaintiff to satisfy at the outset of the lawsuit, sometimes it is not. For example, in a recent securities fraud action the Seventh Circuit upheld summary judgment against plaintiffs who had been denied access to discovery because defendants' motion was based on the statute of limitations and the only issue was the date on which plaintiffs were aware of sufficient facts to put them on notice of the claim. ${ }^{312}$ Defendants relied on plaintiffs' depositions, and the court of appeals rejected the argument that summary judgment should be deferred pending discovery by plaintiffs because " $[t]$ he plaintiffs were the only people who would possibly be in possession of information sufficient to counter the inferences of a lack of due diligence found in their depositions."313

The plaintiff must also show that the requested discovery is likely to provide grounds for denying the motion, ${ }^{314}$ a requirement said to apply even where the information sought is exclusively in the defendant's possession. ${ }^{315}$ The court need not credit speculation that some controverting facts might be discovered. As one court explained, "[i]t is not enough [for the plaintiff] to rest upon the uncertainty which broods over all human affairs or to pose philosophic doubts regarding the conclusiveness of evidentiary facts." 316 There should be some articulated justification for expecting the discovery to unearth evidence that will rebut the defendant's showing.

Evaluating the plaintiff's justification may, however, prove extremely difficult. For example, in Decker v. Massey-Ferguson Ltd., ${ }^{317}$ where the Second Circuit upheld dismissal of the plaintiff's securities complaint based on a comparison of plaintiff's allegations with the contents of various reports issued by Massey, it might well be that had the defendants' motion been treated as one for summary judgment there would have been no need for discovery. Certainly, the appellate court's conclusions that Massey's filings showed conclusively that its forecasts

312. See Gieringer v. Silverman, 731 F.2d 1272 (7th Cir. 1984).

313. Id. at 1278 .

314. See United States ex. rel. Small Business Admin. v. Light, 766 F.2d 394, 397-98 (8th Cir. 1985); Willmar Poultry Co. v. Morton-Norwich Prods., 520 F.2d 289, 297 (8th Cir. 1975), cert. denied, 424 U.S. 915 (1976); see also Reasor v. City of Norfolk, 606 F. Supp. 788, 792 (E.D. Va. 1984) (court granted Rule 56(f) request but cautioned plaintiffs' attorneys that they might be sanctioned if they did not thereafter timely comply with Rule 11). If the information that the plaintiff seeks is not relevant to the motion, the court should proceed to rule. See First Jersey Nat'l Bank v. Dome Petroleum, Ltd., 723 F.2d 335, 341 \& n.4 (3d Cir. 1983); Exxon Corp. v. FTC, 663 F.2d 120, 126-29 (D.C. Cir. 1980).

315. See Weir v. Anaconda Co., 773 F.2d 1073, 1083 (10th Cir. 1985); 6 Moore's Federal Practice, supra note 40, I 56.24, at 56-1432.

316. Robin Constr. Co. v. United States, 345 F.2d 610, 614 (3d Cir. 1965); accord Neely v. St. Paul Fire \& Marine Ins. Co., 584 F.2d 341, 344 (9th Cir. 1978) ("An opposing party's mere hope that further evidence may develop prior to trial is an insufficient basis upon which to justify denial of the motion.").

317. 681 F.2d 111 (2d Cir. 1982); see supra notes 196-207 and accompanying text. 
were not actionable ${ }^{318}$ and that Massey had complied with applicable SEC requirements ${ }^{319}$ suggest this result. But the court's reliance on "unchallenged" figures in Massey's reports to show that plaintiff was wrong in claiming Massey's statements were false ignores the possibility that discovery might have enabled plaintiff to challenge these figures. 320 The possibility, however, need not cause the court to pause unless there were some reasonable prospect that discovery would in fact provide a basis for challenging the figures, and the plaintiff has the burden of specifying why that is true. At some point the off chance that incriminating evidence might surface through discovery is not enough to shake the court's confidence that, as the Second Circuit held in the dismissal posture in Decker, there is no legitimate claim against defendants.

Contrast, however, Ross v. A.H. Robins Co. ${ }^{321}$ in which the Second Circuit rejected the plaintiff's allegations about defendants' awareness of the risks of the Dalkon Shield. Shifted into the summary judgment context, that case presents a situation in which a court could not reasonably conclude that the defendants were free of the alleged awareness without allowing some discovery. In fact, discovery is usually necessary to give plaintiff access to controverting evidence on state of mind issues.

The proper focus here, as with merits decisions on dismissal motions, ${ }^{322}$ is on the level of confidence that the defendant has not violated the plaintiff's rights. A court may be more comfortable in granting summary judgment for the defendant than in deciding dismissal motions in defendant's favor because summary judgment can be granted, even if the plaintiff makes no showing in opposition, only where the defendant has affirmatively demonstrated that there are no disputed issues of fact. ${ }^{323}$

Rule 56(f) requests, however, generally should be liberally

318. See supra note 202 and accompanying text.

319. See id.

320. See supra note 203 and accompanying text.

321. 607 F.2d 545 (2d Cir. 1979), cert. denied, 446 U.S. 946 (1980); see supra notes $91-93$ and accompanying text.

322. See supra notes $144-95$ and accompanying text.

323. See, e.g., Adickes v. S.H. Kress \& Co., 398 U.S. 144, 160 (1970); First Nat'l Bank v. Cities Serv. Co., 391 U.S. 253, 289 (1968). Thus, in Catrett v. Johns-Manville Sales Corp., 756 F.2d 181 (D.C. Cir.), cert. granted sub nom. Celotex Corp. v. Catrctt, $106 \mathrm{~S}$. Ct. 342 (1985), the court reversed the grant of summary judgment to defendant because defendant had made no showing in support of its motion even though it appeared that plaintiff (who had the burden of proof) had no admissible evidence to oppose the motion. Judge Bork dissented, arguing that summary judgment is permissible where the plaintiff has no evidence. 1d. at 187-91. It is possible the Supreme Court may' use this case as a vehicle for revising the rule on this issuc. Cf. Fontenot v. Upjoln Co., 780 F.2d 1190, 1197 (5th Cir. 1980) (rejecting decision of D.C. Circuit in Calrell). 
granted. ${ }^{324}$ Nonetheless, they need not raise the spectre of voluminous discovery. To the contrary, Rule 56(f) contemplates only limited discovery, ${ }^{325}$ and the plaintiff's showing under Rule 56(f) should focus that discovery effort. Moreover, the court could authorize such discovery in stages, reviewing the results of one stage before deciding whether to authorize another. ${ }^{326}$ Such scrutiny of discovery results is well adapted to the emerging case management orientation of federal judges; discovery can be directed toward critical issues and assessed as it is completed to determine whether summary disposition of part or all of the case is then possible. ${ }^{327}$ Although excessive limitations may generate unnecessary disputes about the scope of discovery, ${ }^{328}$ the court's power to tailor the discovery to the needs of the case limits the litigation boom risks that apparently prompted courts to adopt stringent fact pleading requirements in the first place. ${ }^{329}$ In cases like Decker, the decision whether to allow any discovery may be extremely difficult, but if the Rule 56(f) issue is framed in terms of confidence that the defendant has not violated the plaintiff's rights, the court will at least be addressing the right basic problem.

Unfortunately, some courts seem instead to take the same approach as the new fact pleading cases and deny Rule 56(f) requests because the plaintiff presently lacks evidence, even though the issue seems to call for discovery. In Paul Kadair, Inc. v. Sony Corp. ${ }^{330}$ for example, the Fifth Circuit recently upheld summary judgment that defendants had not conspired even though the trial court had unilaterally stayed discovery before plaintiff had taken any. Plaintiff, a stereo retailer, sued forty-one manufacturers, distributors, and retailers of elec-

324. See, e.g., Patty Precision, Inc. v. Brown \& Sharpe Mfg., 742 F.2d 1260, 1264 (10th Cir. 1984); 10A C. Wright \& A. Miller, supra note 3, § 2740, at 530-32.

325. See First Nat'l Bank v. Cities Serv. Co., 391 U.S. 253, 265 (1968) ("comparatively limited discovery"); see also id. at 298 ("discovery obtainable under Rule 56(f) . . . would normally be less extensive in scope").

326. For a discussion of such a process in a related context, see Durham \& Dibble, Certification: A Practical Device for Early Screening of Spurious Antitrust Litigation, 1978 B.Y.U. L. Rev. 299. In Reiter v. Sonotone Corp., 442 U.S. 330 (1979), the Court cited this article with apparent approval while observing that "[d]istrict courts must be especially alert to identify frivolous claims brought to extort nuisance settlements ... Id. at 345 .

Plaintiff's attorneys may have an incentive to screen discovery results in this fashion by themselves. Professor Coffee suggests that they may lose interest in cases in which limited discovery does not turn up a "smoking gun." See Coffee, supra note 136. To the extent he is correct, the courts may feel less need to intervene in the process.

327. For a discussion of such control of discovery, see W. Schwarzer, Managing Antitrust and Other Complex Litigation § 3-3, at 62-63 (1982). Limitations on discovery can cause problems of their own, however. See Shaklee Corp. v. Gunnell, 748 F.2d 548 (10th Cir. 1984) (limitations on discovery denied defendants due process when matters deemed irrelevant during discovery became relevant during trial).

328. See $10 \mathrm{~A}$ C. Wright \& A. Miller, supra note $3, \S 2740$, at 541 .

329. See supra notes $45-105$ and accompanying text.

330. 694 F.2d 1017 (5th Cir. 1983). 
tronic equipment, charging that they conspiratorially refused to deal with plaintiff. A month after the complaint was filed, the trial court sua sponte stayed all discovery pending a status conference in order to "protect the plaintiff from a barrage of paper work." 331 The stay remained in effect, subject to the right to request specified discovery. ${ }^{332}$ After the trial court twice ordered plaintiff to amend its complaint to set forth specific and detailed allegations as to each defendant, defendants filed motions for summary judgment supported by affidavits denying conspiratorial activity and specifying other reasons such as lack of creditworthiness for refusing to deal with plaintiff. Plaintiff responded with an affidavit seeking discovery pursuant to Rule 56(f), eventually identifying fifteen individuals it wanted to depose, and specifying certain subjects it wished to cover in interrogatories. Emphasizing plaintiff's admission that it filed suit with limited evidence, ${ }^{393}$ the trial court found Rule 56(f) inapplicable because that Rule "is designed to enable a party to seek particular facts relevant to an already-established factual pattern of alleged antitrust activity." 334 Since plaintiff could not assure the court that the proposed discovery would produce evidence suffcient to oppose defendants' motions, the court refused to allow it to conduct a "fishing expedition," 335 and granted defendants' motions.

While troubled by indications that plaintiff's counsel had not undertaken discovery because he had been busy responding to defendants' motions, ${ }^{336}$ the Fifth Circuit affirmed. It commended the trial court's efforts to keep discovery under control, 337 pointing out that "the expensive and time consuming nature of antitrust litigation along with the statutory treble damage remedy, may particularly inspire vexatious litigation, an evil which summary judgment may guard against."338 Noting that plaintiff failed to submit affidavits on matters within its control, such as creditworthiness, and that its discovery requests "remained vague and peripheral to the key issue of conspiracy,"339 the appellate court found persuasive the views of the Second Circuit that " $[w]$ here a plaintiff fails to produce any specific facts whatsoever to support a conspiracy allegation, a district court may, in its

331. See Paul Kadair, Inc. v. Sony Corp., 88 F.R.D. 280, 284 (M.D. La. 1980), afTd, 694 F.2d 1017 (5th Cir. 1983).

332. The appellate court stated that the stay was not unequivocal about allowing discovery. See 694 F.2d at 1031. But it appears that defendants' motions were filed before the earliest time when the district court's stay order contemplated allowing any discovery. See id.

333. 88 F.R.D. at $284,285$.

334. Id. at 289.

335. Id. The court explained that "the purpose of discovery . . . would be to ascertain whatever information possible in order to set forth specific violations of the Act." 336. See 694 F.2d at 1023 n.12.

337. Id. at 1024 n. 18 .

338. Id. at 1031 .

339. Id. at 1032 . 
discretion, refuse to permit discovery and grant summary judgment." 340 Under the peculiar facts of Kadair, the court's refusal to permit plaintiff any discovery may have been justified because the likelihood that plaintiff would turn up evidence of wrongdoing was so slight. In general, however, the idea that plaintiffs should be required to make an evidentiary showing to justify access to discovery raises most of the same problems as using pleadings practice to challenge plaintiff's factual conclusions. ${ }^{341}$

Precise or general rules for Rule 56(f) decisions cannot be fashioned; ultimately, courts will have to make sensible decisions on a caseby-case basis. In evaluating the scope of discovery that will be permitted, they are likely to consider many of the factors that have already been rejected as justifications for heightened pleading standards. They are also likely to encounter difficult problems in determining whether a certain amount of discovery is enough. But confronting these difficulties is better, in an imperfect world, than pretending that the same issues can be resolved at the pleading stage. Some evidence is better than none, and discretionary control of discovery (explicitly authorized by the Rules) ${ }^{342}$ is much less unsettling than discretion to dismiss. So long as the basic focus is on whether the court can confidently conclude that the defendant did not in fact violate the plaintiff's rights, sensible judges should reach sensible results.

\section{CONCLUSION}

I fear that every age must learn its lesson that special pleading cannot be made to do the service of trial and that live issues between active litigants are not to be disposed of or evaded on the paper pleadings ....

Charles E. Clark ${ }^{343}$

This Article began by asking whether Clark's pessimism based on

340. Id. at 1030 (quoting Contemporary Mission, Inc. v. United States Postal Serv., 648 F.2d 97, 107 (2d Cir. 1981)).

341 . For a discussion of those problems, see supra notes 209-27 and accompanying text. Where, after reasonable discovery, the plaintiff cannot persuasively challenge the defendant's assertions, a court may comfortably decide against the plaintiff. See, e.g., Sames v. Gable, 732 F.2d 49 (3d Cir. 1984) (upholding summary judgment against claims that plaintiffs were demoted for political reasons on basis of defendant's denials of any such motivations in their depositions, in light of plaintiffs' failure to proffer any other evidence).

Lest Kadair be thought unique, see Wallace v. Brownell Pontiac-GMC Co., 703 F.2d 525 (11 th Cir. 1983) (defendants granted summary judgment before plaintiff had opportunity for discovery); Willmar Poultry Co. v. Morton-Norwich Prods., Inc., 520 F.2d 289 (8th Cir. 1975) (same), cert. denied, 424 U.S. 915 (1976). But cf. Sonenshein, supra note 299 , at 785 (summary judgment inappropriate when party opposing motion has not had opportunity to complete discovery).

342. Note that the wording of Rule 56(f) is discretionary, see supra note 310 . See also supra note 62 and accompanying text.

343. Clark, supra note 71 , at 46. 
Gresham's Law has been vindicated by the judicial handling of his pleading reforms. Certainly Rule $8(a)(2)$ has not received the brutal treatment the New York judges inflicted on the Field Code. ${ }^{344}$ Furthermore, Conley $v$. Gibson effectively scotched any serious efforts to revert to code pleading formalism. It is equally clear, however, that the new fact pleading is more restrictive than Clark would have wanted. The courts' efforts to puncture factual conclusions are inconsistent with the spirit of the Rules, and the present handling of legal conclusions would probably offend a reformer who originally wanted to do away with pleading motions altogether. ${ }^{345}$ So Gresham's Law seems at least partly at work, but the courts are not the only ones who have been its instruments. Clark probably would have opposed some of the 1980 and 1983 amendments to the Federal Rules of Civil Procedure; ${ }^{346}$ whether as a result of Gresham's Law or other developments, time seems to have tarnished his vision of the litigation system.

The obvious stimulus for the new fact pleading is the litigation boom, and the fact pleading cases are therefore concentrated in the areas that have experienced the greatest growth. The prospect that liberal pleading affords broad discovery to abusive litigants or lawyers is undeniably distressing. But the circumstances do not actually seem so urgent as portrayed by many. Rapid growth in the level of civil litigation is not unknown in English and American experience. ${ }^{347}$ Although the public perception of the problem has been concentrated in the last decade or two, judicial lobbying about protracted litigation goes back nearly four decades. ${ }^{348}$ Moreover, the frequency of abusive practices by plaintiffs has not been shown to be high. ${ }^{349}$ Indeed, some have gone so far as to label the current preoccupation with the litigation boom "an item of elite folklore." 350 Under these circumstances, there seems to be little reason for radical retrenching on the handling of pleadings, even if that were a promising solution.

The real question is whether pleading practice can yield reliable merits decisions. The prevalence of notice pleading jargon has obscured this question by forcing courts interested in disposing of cases on the merits to couch their decisions in terms of demanding notice of the basis of the claim. The pressures of the litigation boom could have the desirable effect of ending this camouflage effort. This Article has therefore suggested that the notice pleading rationale be abandoned. Unless there is some prospect that it will lead to a merits decision of

344. See supra note 29 and accompanying text.

345. See supra note 34 and accompanying text.

346. Cf. F. James \& G. Hazard, supra note 11 , § 3.11 , at 154-55 (characterizing requirement under amended Rule 11 of statement of factual grounds for a claim as "a move in the direction of code pleading").

347. See supra note 46 and accompanying text.

348. See supra notes 47-48 and accompanying text.

349. Cf. supra note 140 and accompanying text (relating to class actions).

350. Galanter, supra note 46 , at 64 . 
some or all of the claims or defenses, pleading practice is little better than an expensive waste of time. ${ }^{351}$

Once the notice pleading chimera is banished, very difficult problems remain. Under the Federal Rules, there is a systemic tendency to react to the risk of inaccurate decisions by adding procedural layers intended to improve accuracy. Laudable in theory, this tendency can deprive litigants of any decision on the merits; ${ }^{352}$ failure to dismiss a weak case or grant summary judgment may be something of a default in the judicial function. Sometimes a decision, even with some risk of error, may be preferable to the drain of continued litigation. If the litigation boom causes the courts to come to grips with this responsibility, that is also desirable.

The circumstances in which such merits decisions are possible on the pleadings, however, are distressingly limited. This Article has found that such situations fall generally into two categories, those in which more detail will reveal a fatal defect and those in which sufficient detail will show that the defendant has not violated the plaintiff's rights. ${ }^{353}$ As the recent experience under RICO demonstrates, ${ }^{354}$ it is often difficult to identify elements of a claim that plaintiffs should be forced to establish. Even more troubling is the risk that courts will indulge in weighing of evidence in the process of trying to decide on the basis of the pleadings whether the defendant's conduct violated the plaintiff's rights. Outside these limited areas, more stringent pleading practices cannot be justified as appropriate for "suspicious" cases ${ }^{355}$ or as part of the trial court's discretion in handling litigation. ${ }^{356}$

Instead, more flexible use of summary judgment, in tandem with case management, seems the more promising course. ${ }^{357}$ This approach reduces the disquieting possibility that a plaintiff will be unable to satisfy the court's demand for proof of the defendant's misconduct because he has been denied discovery. It is also comforting to have merits decisions based on evidence rather than allegations. Moreover, selective cost-shifting, coupled with active case management, should di-

351. See supra notes 113-21 and accompanying text.

352. Justice Rehnquist, for example, has remarked on the effect of the "seeming compulsion to make sure that the final result reached in any case is the correct one." Relınquist, Speech at University of Florida Law School (Sept. 15, 1984) at 16 (unpublished) (on file at the offices of the Columbia Law Review). This compulsion has had an effect on the design of the litigation system: "It is very much as if the government were to announce a governmental monopoly on the production of cars, and then proceed to produce only Cadillac limousines with jump seats." Id. at 14; see also Leubsdorf, Constitutional Civil Procedure, 63 Tex. L. Rev. 579, 589 (1984) ("Those who are not rich often cannot afford litigation on the scale for which the system is designed.").

353. See supra notes $149-95$ and accompanying text.

354. See supra notes $154-71$ and accompanying text.

355. See supra notes 228-77 and accompanying text.

356. See supra notes $278-96$ and accompanying text.

357. See supra notes $297-342$ and accompanying text. 
minish some concerns about litigation abuse. ${ }^{358}$ This course is neither easy nor foolproof, however. Case management is time-consuming and vexing, and Rule 56(f) requests for postponements will often require particularly difficult determinations about the utility of further discovery. Evaluating evidence in the summary judgment context is not easy, but it should be more reliable than scrutinizing factual conclusions in the pleadings. Thus, the suggestion is simply a better course, not a panacea.

In the end, Clark's pessimism seems to reflect the cyclical nature of procedural reform. For more than a century reform efforts in England and America have followed a similar course, with simplifications breeding new complexities. ${ }^{359}$ To a large extent, these difficulties result from shifting uncertainties about substantive law. They also result from the fact that we have an adversarial system in which litigants and lawyers try to use the procedures that exist to the advantage of their clients. In the face of these pressures, the reality is that manipulation of procedural mechanisms for settlement leverage will never be eliminated. ${ }^{360}$ As tinkerers, we will have to repeat the cycle of revision and relapse again and again.

358. See supra notes 66,143 and accompanying text.

359. The English Judicature Acts of 1875 represented a watershed similar to the adoption of the Federal Rules. Like the Federal Rules, the Act was designed to simplify litigation, shelve formalism, expand discovery, and assure decisions on the merits. Within 10 years, excessive litigation, particularly excessive discovery, had run up the cost of litigation so much that it was said the reforms seemed to be defeating their own ends. See Rosenbaum, Studies in English Procedure, 63 U. Pa. L. Rev. 273, 289-9 (1915). Among the remedies proposed for this situation were elimination of pleadings, id. at 295, 382, and requiring closer supervision of discovery by masters, id. at 386 .

360. Cf. Weinstein, Some Reflections on the "Abusiveness" of Class Actions, 58 F.R.D. 299, 302 (1973) ("As in any litigation, the pressure on the defendant to buy his peace through settlement cannot be totally eliminated."). 


\section{COLUMBIA LAW REVIEW}

VOL. 86

APRIL 1986

NO. 3

\section{THE REVIVAL OF FACT PLEADING UNDER THE FEDERAL RULES OF GIVIL PROGEDURE}

\section{Richard L. Marcus*}

Unfortunately by a kind of Gresham's Law, the bad, or harsh, procedural decisions drive out the good, so that in time a rule becomes entirely obscured by its interpretive barnacles.

Charles E. Clark ${ }^{1}$

As Dean of Yale Law School and reporter of the committee that drafted the Federal Rules of Civil Procedure, Charles Clark ${ }^{2}$ was the principal architect of the Rules and leading proponent of the liberal ethos that underlies them. His pessimism about procedural reform therefore deserves attention. This Article examines the fate of the centerpiece of Clark's new system-simplified pleading under Rule 8(a)(2), which requires only "a short and plain statement of the claim showing that the pleader is entitled to relief."3 This Rule was designed to escape the complexities of fact pleading under the codes, which had generated great confusion about how to allege the required "ultimate facts" while avoiding forbidden "conclusions" and "mere evidence." There were pockets of resistance against the new pleading rules in the years after $1938,{ }^{4}$ but in 1957 the Supreme Court threw its weight decisively behind the new liberal ethos in Conley $v$. Gibson: 5 "[A] complaint should not be dismissed for failure to state a claim unless it appears

* Professor of Law, University of Illinois. B.A. 1969, Pomona; J.D. 1972, University of California, Berkeley. I received numerous helpful suggestions from the participants in an Illinois Faculty Workshop that discussed some of these ideas. In addition, I am indebted to United States District Judge Milton Shadur (N.D. Ill.) and Jan Vetter, who reviewed earlier drafts of this Article and made numerous helpful comments, and to Ed Wilhoite who provided valuable research assistance. All errors that remain are mine alone.

1. Clark, Special Problems in Drafting and Interpreting Procedural Codes and Rules, 3 Vand. L. Rev. 493, 498 (1950).

2. Charles Clark graduated from Yale Law School in 1913, and began to teach there in 1919. From 1929 to 1939 he was Dean. In 1939, he was appointed a judge of the Second Circuit, of which he served as Chief Judge from 1954 to 1959 . From 1935 to 1956 he served as Reporter of the Supreme Court's Committee on the Rules of Civil Procedure, which drafted the rules. See 4 Who Was Who in America 174 (1968).

3. Fed. R. Civ. P. 8(a)(2); see also 5 C. Wright \& A. Miller, Federal Practice \& Procedure $\S 1202$, at 59 (1969) ("Rule 8 is the keystone of the system of pleading embodied in the federal rnles."); Smith, Judge Charles E. Clark and The Federal Rules of Civil Procedure, 85 Yale L.J. 914, 917-I8 (1976) (general pleading was one of Clark's thrce basic goals for new procedural rules).

4. Sce infra notes $69-71$ and accompanying text.

5. 355 U.S. 41 (1957). 
beyond doubt that the plaintiff can prove no set of facts in support of his claim that would entitle him to relief." 6 Clark could hardly have put it more forcefully himself.

Although Conley $v$. Gibson put the Supreme Court on record as clearly favoring the liberal view, the actual application of its admonition in subsequent cases was more problematic. Taken literally, it might have precluded dismissal in any case where the plaintiff invoked a valid legal theory. How can a court ever be certain that a plaintiff will prove no set of facts entitling him to relief? The case itself provided little help. Plaintiffs were black union members who accused their union of racial discrimination. Defendants argued that the complaint failed to state a claim because it lacked particulars about their allegedly discriminatory activities. The lower courts did not accept that argument, ${ }^{7}$ and the Supreme Court rejected it with the broad statement quoted above. But the complaint did contain particulars, and the case could have been decided without such sweeping language. ${ }^{8}$ The Court's broad language was intended for other cases, not this one. Pleadings were intended only to give general notice, it seemed, and pleading practice was to shrivel and die.

One seeming impact of Conley $v$. Gibson was that commentators lost interest in pleading. For years before and after the adoption of the Federal Rules in 1938, pleading had been the subject of intense academic discussion. ${ }^{9}$ After the decision, this discussion stopped abruptly. Perhaps that was because some viewed the battle about detailed pleadings as irretrievably over, ${ }^{10}$ or because they understood that Conley authorized a "fishing expedition" to determine whether plaintiff actually had a claim. ${ }^{11}$ Whatever the reason, for more than twenty years after Conley, there was virtually no academic recognition that pleading practice had not vanished; defendants continued to make motions to dismiss and courts continued to grant them. Only recently have commentators begun to acknowledge this reality. ${ }^{12}$

6. Id. at $45-46$ (citations omitted).

7. The lower courts had dismissed on the ground that the claim was subject to the exclusive jurisdiction of the Railroad Adjustment Board. The Supreme Court rejected that argument. See id. at $43-44$.

8. Plaintiffs alleged, for example, that the defendant union maintained two separate locals, one for whites and the other for blacks, providing inferior representation to the black local, see Complaint II VI, VII, Transcript of Record at 8-11, Conley, and that in May, 1954, with the connivance of the union, the railroad had fired 45 blacks and replaced them with whites, see Complaint II VIII, X, Transcript of Record at 11-13.

9. For a collection of such authorities, see Weinstein \& Distler, Drafting Pleading Rules, 57 Colum. L. Rev. 518, 524-25 (1957).

10. See, e.g., Friedenthal, A Divided Supreme Court Adopts Discovery Amendments to the Federal Rules of Civil Procedure, 69 Calif. L. Rev. 806, 816 (1981) ("Once it became clear that the battle for a return to the code formulation was irretrievably lost, other devices were utilized to raise the same issue in different contexts.").

11. F. James \& G. Hazard, Civil Procedure $\$ 3.11$, at 153-54 (3d ed. 1985).

I2. This commentary tends to focus on narrow problems rather than the more gen- 
Not only has pleading practice survived, but fact pleading, the bête noir of the codes, seems to be enjoying a revival in a number of areas in which courts refuse to accept "conclusory" allegations as sufficient under the Federal Rules. Consider, for example, Heart Disease Research Foundation v. General Motors Corp., ${ }^{13}$ which the Guinness Book of World Records listed as the suit with the largest damage claim in the history of litigation, $\$ 375$ trillion. ${ }^{14}$ Plaintiff sued on behalf of a class of 125 million American urban dwellers alleging that the defendant Big Four automakers had conspired in violation of the Sherman Antitrust Act to restrain the development of automobile air pollution mechanisms, thereby polluting the atmosphere of North America. The Second Circuit affirmed the trial court's dismissal for failure to state a claim ${ }^{15}$ because "it was well within the district court's discretion to dismiss the claim since no facts are alleged supporting an antitrust conspiracy. Although the Federal Rules permit statement of ultimate facts, a bare bones statement of conspiracy or of injury under the antitrust laws without any supporting facts permits dismissal."16 This attitude appears worlds away from the approach articulated in Conley. The result becomes more remarkable when one considers that the United States had also sued the Big Four alleging the same conspiracy, and ultimately obtained a consent decree in that litigation for "essentially all" the relief it had sought. ${ }^{17}$ The dismissal upheld by the Second Circuit was certainly correct on other grounds, ${ }^{18}$ but it illustrates that Conley is not

eral question of the role of pleadings in the modern litigation system. See, e.g., Roberts, Fact Pleading, Notice Pleading, and Standing, 65 Cornell L. Rev. 390, 399-400, 415 (1980); Saveri \& Saveri, Pleading Fraudulent Concealment in an Antitrust Price Fixing Case: Rule 9(b) v. Rule 8, 17 U.S.F.L. Rev. 631, 639-40 (1983); Sovern, Reconsidering Federal Civil Rule 9(b): Do We Need Particularized Pleading Requirements in Fraud Cases?, 104 F.R.D. 143, 150 (1985); Wingate, A Special Pleading Rule for Civil Rights Complaints: A Step Forward or a Step Back?, 49 Mo. L. Rev. 677, 680-83 (1984); Note, Pleading Sccurties Fraud Claims With Particularity Under Rule 9(b), 97 Harv. L. Rev. 1432 (1984).

13. 463 F.2d 98 (2d Cir. 1972).

14. N. McWhirter \& R. McWhirter, Guinness Book of World Records 387 (12th ed. 1973). The case has since been eclipsed by more ambitious litigation. See Windsor v. Pan American Airways, 744 F.2d 1187 (5th Cir. 1984) (suit for $\$ 400$ trillion).

15. The district court had relied in the alternative on Fed. R. Civ. P. 11. See Heart Disease Research Found. v. General Motors Corp., 15 Fed. R. Serv. 2d (Callaghan) 1517, 1519 (S.D.N.Y. 1972). The Second Circuit chose not to rely on that ground. See 463 F.2d at 100 .

16. $463 \mathrm{~F} .2 \mathrm{~d}$ at 100 .

17. This litigation was filed, along with the massive antitrust suit against I.B.M., in the last days of the Johnson Administration. See R. Harris, Justice I28 (1970). The government suit charged a conspiracy beginning at least as early as 1953 to retard competition in the development of air pollution control equipment. After negotiations, the government and the automakers agreed to a consent judgment in October, 1969, which "granted essentially all of the relief which the government had sought." United States v. Motor Vehicle Mfrs. Ass'n, 643 F.2d 644, 645 (9th Cir. I981).

18. As a nonprofit foundation, the plaintiff had no standing to sue for damages under the antitrust laws. Cf. In re Multidistrict Vehicle Air Pollution, 481 F.2d 122 (9th 
taken literally. This case, moreover, is not an anomaly. Although they rarely acknowledge the shift, ${ }^{19}$ federal courts are insisting on detailed factual allegations more and more often, particularly in securities fraud and civil rights cases. ${ }^{20}$

Does the revival of fact pleading show that Clark was right to expect the courts to undermine his liberal reforms with restrictive barnacles? Using this question as a starting point for an analysis of the proper role of pleadings under the Federal Rules, this Article concludes that reality is more complicated. The new fact pleading is an effort to cope with the pressures of the litigation boom, itself caused in part by the innovations of the Federal Rules. Contrary to the conventional wisdom that the sole purpose of pleadings is to give notice, this Article suggests that their role should be to enable courts to decide cases on their merits. The important question then is how pleading rules can be used to accomplish that purpose. Unfortunately, operating in the shadow of Conley $v$. Gibson and caught up in the vocabulary of notice pleading, the courts have not given that question much attention.

This Article finds that the answer is to look for cases in which the plaintiff's legal conclusions can be profitably evaluated. It identifies two broad categories of such cases-those in which more specificity is likely to disclose a fatal defect in a plaintiff's case, and those in which sufficient detail will enable the court to make a reliable determination that the defendant did not violate the plaintiff's rights. Used in this fashion, pleading practice is an important tool, but not a panacea. In other kinds of cases, whether purportedly justified as providing "notice" or otherwise, pleading motions are largely a waste of time.

The new fact pleading does not stop with these two kinds of cases, however. Courts now regularly use it, as in Heart Disease Research Foundation, to probe and reject plaintiff's factual conclusions. Although this practice is understandable in view of the breadth of modern discovery and the limits on summary judgment, it does not provide a reliable method for determining whether a defendant has violated the plaintiff's rights because it requires the plaintiff to marshall evidence before conducting discovery. Neither can it be justified as a special way of handling certain "suspicious" claims or as a step toward discretionary dismissals. Instead, the preferable route for probing plaintiff's factual conclusions should be to rely on more flexible use of summary judgment. Under this approach, the principal focus would often be on the

Cir.) (holding that state governments and crop farmers lacked standing to seek damages in litigation over same conspiracy), cert. denied, 414 U.S. 1045 (1973).

19. See Roberts, supra note 12, at 420 ("What is most noteworthy about this slow erosion of federal notice pleading . . . is the utter silence in which the process is taking place."). For a review of the new fact pleading cases, see infra notes 84-104 and acconpanying text.

20. See infra notes 84-101 and accompanying text. 
amount of discovery to be allowed a plaintiff under Rule $56(\mathrm{f})$ before ruling on summary judgment, thereby controlling the risk of abuse of discovery. Such flexible use of summary judgment would be particularly effective if done in conjuction with more active case management by judges. Combined with selective cost-shifting in cases of proven litigation abuse, this evidentiary scrutiny would provide a better system for pretrial disposition.

\section{The Evolution and Corruption of Simplified Pleading}

\section{A. The Sins of the Past}

In pleading, they studiously avoid entering into the Merits of the Cause; but are loud, violent and tedious in dwelling upon Circumstances which are not to the Purpose.

Jonathan Swift ${ }^{21}$

Common law pleading, which was originally oral, evolved over centuries into an increasingly detailed written exercise. During the same period, the forms of action were developing, and their limitations reinforced pleading difficulties. In order to prevail, the common law plaintiff had to choose the correct form of action. He and his lawyer then embarked on an exchange of pleadings with the defendant that was designed ultimately to produce a single issue for resolution by a judge or trial by a jury, ${ }^{22}$ with trial itself as something of an afterthought to the pleading process. ${ }^{23}$

Whatever the wisdom of the common law approach as an abstract system, it proved extremely susceptible to Gresham's Law. Over time, it became necessary to use highly stylized verbal formulations to present even simple grievances. These expressions-known as "color"often had little relation to the underlying facts of the particular case. ${ }^{24}$ They certainly told the defendant little or nothing about the plaintiff's claims, and the defendant would remain in the dark until trial because discovery was limited or nonexistent. Nevertheless, the defendant could take comfort in the prospect that the plaintiff could ultimately lose because his lawyer bungled the pleading war. As pleading practice prospered, decisions on the merits became increasingly infrequent. ${ }^{25}$ 1726).

21. J. Swift, Gulliver's Travels 352-53 (H. Williams ed. 1926) (1st ed. London

22. For a description of this ritual, see A. Harding, The Law Courts of Medieval England 78-79 (1973).

23. R. Palmer, The County Courts of Medieval England 90 (1982); see also A. Harding, supra note 22, at 78 ("Cases were often decided by the pleading-contest rather than by jury or the other methods of trial.") (citation omitted).

24. On the growth of legal fictions, see Sutherland, Legal Reasoning in the Fourteenth Century: The Invention of "Color" in Pleading, in On the Laws and Customs of England, Essays in Honor of Samuel Thorne 182 (M. Arnold, T. Green, S. Scully \& S. White eds. I98I).

25. See F. James \& G. Hazard, supra note I1, § 3.2, at 132. 
Popular dissatisfaction with this situation in England led, in the late nineteenth century, to abandonment of the forms of action and simplification of pleading. ${ }^{26} \mathrm{~A}$ movement for similar reforms in this country was spearheaded by David Dudley Field, the drafter of the New York code adopted in 1848. While one may question whether American judges were really so formalistic as the reformers suggested, ${ }^{27}$ it was clear that the Field Code reforms were intended to eliminate decisions based on technicalities. In place of stylized verbiage, the Code directed that the complaint contain "[a] statement of the facts constituting the cause of action, in ordinary and concise language, without repetition, and in such a manner as to enable a person of common understanding to know what is intended." 28

The high hopes for the Field Code were not realized. In part, one may attribute this failure to judicial sabotage. ${ }^{29}$ No doubt the Code's fate was what Clark had in mind when he spoke of Gresham's Law. But there were real problems with the codifier's reformulation of pleading rules in that they invited unresolvable disputes about whether certain assertions were allegations of ultimate fact (proper), mere evidence (improper), or conclusions (improper). ${ }^{30}$ In particular, there was great difficulty distinguishing ultimate facts from conclusions since so many concepts, like agreement, ownership and execution, contain a mixture of historical fact and legal conclusion. Pleading decisions caused increasing difficulty for even the most common claims. For example, the detail needed to allege negligence was regularly recalibrated. ${ }^{31}$ Such fencing among lawyers led to stagnation that interfered with resolution of disputes on their merits.

26. See generally 15. W. Holdsworth, A History of English Law 128-32 (A. Goodhard \& H. Hanbury ed. 1965) (describing the Judicature Act of 1873, which simplified pleading in England).

27. Indeed, the Field Code itself may be viewed as an example of 19 th century formalism. See M. Horwitz, The Transformation of American Law 265-66 (1977).

28. An Act to simplify and abridge the Practice, Pleadings and Proceedings of the Courts of this State, ch. 379, $\$ 120(2), 1848$ N.Y. Laws 521.

29. See McArthur v. Moffet, 143 Wis. 564, 567, 128 N.W. 445, 446 (1910) (reforring to "[t]he cold, not to say inhuman, treatment which the infant Code received from the New York judges").

30. See Cook, Statements of Fact in Pleading Under the Codes, 21 Colum. L. Rev. 416,417 (1921), for an argument that these distinctions are ultimately meaningless. But cf. McCaskill, Actions and Causes of Action, 34 Yale L.J. 614, 620 (1925) (arguing that cause of action concept must be retained because pleadings will otherwise be "half baked and undigestible").

31. See, e.g., Gillispie v. Goodyear Serv. Stores, 258 N.C. $487,490,128$ S.E.2d 762 , 765 (1963) (" "N]egligence is not a fact in itself, but is the legal result of cortain facts." ") (quoting Shives v. Sample, 238 N.C. 724, 726, 79 S.E.2d 193, 195 (1953)); cf. C. Clark, Handbook of the Law of Code Pleading $\$ 47$, at 300-03 (2d ed. 1947) (noting that requirements for pleading negligence under code pleading werc actually morc dcmanding than under common law). 


\section{B. The Federal Rules: The Liberal Ethos Triumphant}

Ancestor worship in the form of ritualistic pleadings has no more disciples. The time when the slip of a sergeant's quill pen could spell death for a plaintiff's cause of action is past. Under the Federal Rules of Civil Procedure, a complaint is not an anagrammatic exercise in which the pleader must find just exactly the prescribed combination of words and phrases.

$$
\text { Judge John Minor Wisdom }{ }^{32}
$$

Sobered by the fate of the Field Code, Dean Clark and the other drafters of the Federal Rules set out to devise a procedural system that would install what may be labelled the "liberal ethos," in which the preferred disposition is on the merits, by jury trial, after full disclosure through discovery. ${ }^{33}$ At first, Clark favored eliminating pleading motions altogether. ${ }^{34}$ Ultimately other voices held sway, but Rule 8(a)(2) was drafted carefully to avoid use of the charged phrases "fact," "conclusion," and "cause of action." To make the point clearer, the drafters prepared a series of form complaints that were by definition sufficient to satisfy the new standard. ${ }^{35}$ These forms were startlingly brief. For example, Form 9 preempted decades of pleading litigation by declaring sufficient the allegation that "defendant negligently drove a motor vehicle against plaintiff." 36 No longer would the objection that negligence was a legal conclusion hold sway.

Clark did not expect that most complaints would be as abbreviated as the form complaints, and he hoped that most pleaders would continue to do their pleading carefully. ${ }^{37}$ Nonetheless, he had little pa-

32. Thompson v. Allstate Ins. Co., 476 F.2d 746, 749 (5th Cir. 1973).

33. See Clark, The Handmaid of Justice, 23 Wash. U.L.Q. 297, 3I8-19 (I938) (denouncing attempts to resolve cases on pleadings and asserting that "in the case of a real dispute, there is no substitute anywhere for a trial"); see also infra text accompanying note 343 .

This is not to say that all the framers of the rules were enthusiastic about jury trial. To the contrary, some have characterized the attitude of the rules' framers as mistrusting juries and preferring resolutions by judges (presumably on summary judgment). See 2I C. Wright \& K. Graham, Federal Practice \& Procedure, § 5025, at I46-51 (1977) (describing "Progressive Procedural Paradigm"). But their hopes for summary judgment were not vindicated by subsequent events, which made summary judgment difficult to obtain. See infra notes 297-303 and accompanying text; cf. Clark, supra, at 318 (summary judgment "is adapted only for rather simple issues where the facts are on the surface"). Instead, under the influence of Conley $v$. Gibson, the customary decision-making method became jury trial, as was desired by Conley's author, Justice Black. See Kaufman, The Federal Civil Rules and the Pursuit of Justice, in Hugo Black and the Supreme Court; A Symposium 221, 224-25 (S. Strickland ed. 1967) (Black was the nost vigorous champion of jury trial in Supreme Court history.).

34. Smith, supra note 3 , at 927-28.

35. Fed. R. Giv. P. 84 declares that "[t]he forms contained in the Appendix of Forms are sufficient under the rules and are intended to indicate the simplicity and brevity of statement which the rules contemplate."

36. Form 9, Appendix of Forms, Fed. R. Civ. P.

37. See C. Clark, supra note $31, \S 39$, at 245. 
tience with the use of a "mere formal motion" 38 to challenge the sufficiency of the pleadings because it "really decides nothing of substance."39 Clark's protégé, Professor Moore, emphasized in his treatise that pleadings need "do little more than indicate generally the type of litigation that is involved."40 Rather than dwell on pleading niceties, under the new system litigants were to use the expanded discovery mechanisms provided by the Federal Rules to get to the merits of the case. Armed with that information, they could in appropriate cases move for summary judgment, allowing the court to decide the merits. Normally, however, the proper method for resolving them was trial by jury. ${ }^{41}$

The liberality of the pleading requirements is reflected throughout the Federal Rules. Thus, amendment of pleadings is freely granted, even after trial, 42 and the court is admonished in any event to grant the parties whatever relief they are entitled to after trial, whether they have requested it or not. ${ }^{43}$ By the time Conley $v$. Gibson was decided, the stage seemed set for assuring litigants decisions on the merits.

\section{The Sins of the Present: The Catharsis of the Liberal Ethos}

The history of procedure is a series of attempts to solve the problems created by the preceding generation's procedural reforms.

\section{Professor Judith Resnik ${ }^{44}$}

Whatever their internal symmetry, the Federal Rules contributed to a number of developments that have dismayed a considerable portion of the federal judiciary. Much ink has already been spilled on the litigation "boom" and the crisis in the adversary system, ${ }^{45}$ but dramatic increases in litigation are hardly unprecedented. ${ }^{46}$ The reader none-

38. Dioguardi v. Durning, 139 F.2d 774, 775 (2d Cir. 1944); cf. Gottreich v. San Francisco lnv. Corp., 552 F.2d 866, 867 (9th Cir. 1977) ("We had thought that this kind of nit-picking had disappeared in $1938 \ldots$. ..).

39. Proceedings of the Institute at Washington, D.C. and of the Symposium at New York City 54 (1938). These proceedings were held to publicize the new federal rules.

40. 2A J. Moore \& J. Lucas, Moore's Federal Practice 18.03 , at 8-10 (2d ed. 1985) [hereinafter cited as Moore's Federal Practice]; see Hickman v. Taylor, 329 U.S. 495, 501 (1947) ("The new rules, however, restrict the pleadings to the task of general notice-giving .....").

41. See supra note 33 and accompanying text.

42. See Fed. R. Civ. P. 15(b) (amendment to be allowed unless the objecting party shows prejudice).

43. See Fed. R. Civ. P. 54(c).

44. Resnik, Tiers, 57 S. Cal. L. Rev. 837, 1030 (1984).

45. See, e.g., R. Marcus \& E. Sherman, Complex Litigation: Cases and Materials on Advanced Civil Procedure I-22 (1985).

46. One researcher has found the conditions of 1946 to 1980 in the federal courts similar to those in 1876, when civil cases were more important than criminal. See Clark, Adjudication to Administration: A Statistical Analysis of Federal District Courts in the Twentieth Century, 55 S. Cal. L. Rev. 65, 123 (1981); see also id. at 99-105 (noting 
theless intuits that the existing pressures on the federal judicial system arose, somewhat unexpectedly, within the last twenty years. Things were not actually so tranquil during the Federal Rules' first quarter century, however. Ten years after the Rules were adopted, concern about protracted litigation caused the Judicial Conference of the United States to appoint a committee headed by Judge E. Barrett Prettyman to examine the peculiar problems caused by such litigation. ${ }^{47}$ In 1955, Chief Justice Warren commissioned a special panel of federal judges to study the handling of complicated cases, ${ }^{48}$ a process leading ultimately to the promulgation of the Manual for Complex Litigation. So the pressures of managing litigation were sensed soon after the Federal Rules came into effect. Undeniably, however, these concerns did escalate with the rapid rise in federal court filings during the 1960s and 1970s.

Peering out from behind this mountain of litigation, federal judges also perceived a pro-plaintiff shift in the balance of power in litigation resulting largely from the breadth of discovery, which could impose very substantial costs on defendants. ${ }^{49}$ Moreover, at least some courts said that once the plaintiff had obtained information through discovery he could do anything he wanted with it; discovery could even become the principal objective of a lawsuit, rather than merely a device for helping resolve it. ${ }^{50}$ Other procedural innovations, particularly the 1966 amendment of Rule 23 on class actions, seemed to load the dice in

burst of growth in civil filings between 1900 and 1907). England experienced a litigation boom in the 16 th and 17 th centuries. See Brooks, Litigants and Attorneys in the King's Bench and Common Pleas, 1560-1640, in Legal Records and the Historian 41 (J. Baker ed. 1978). Nor is the duration and magnitude of the current "boom" undisputed. See Galanter, Reading the Landscape of Disputes: What We Know and Don't Know (And Think We Know) About Our Allegedly Contentious and Litigious Society, 31 UCLA L. Rev. 4, 9 (1983) (In 1960, there was concern about a decline in litigation.).

47. The committee's report, entitled Procedure in Anti-trust and Other Protracted Cases, appears at 13 F.R.D. 62 (1951). The report anticipates much of the debate that would develop over the following three decades. Consider the following: "Pleadings will not serve to particularize issues sufficiently in these cases, and motions for particulars will not serve that purpose. Such particularization must be achieved by informal conferences between judge and counsel well in advance of a possible trial date." Id. at 67. This approach was ultimately adopted by the 1983 amendments to the Federal Rules. See infra note 61 and accompanying text.

48. The panel's proposal, entitled Handbook of Recommended Procedures for the Trial of Protracted Cases, appears at 25 F.R.D. 351 (1960).

49. See, e.g., In re Commonwealth Oil/Tesoro Petroleum Corp. Sec. Litig., 467 F. Supp. 227, 250 (W.D. Tex. 1979) ("unchecked access to the in terrorem power of the federal discovery mechanism"). Such argnments echo the debate about pleading specificity during the 1950s. See infra notes 69-71 and accompanying text; New Dyckman Theatre Corp. v. Radio-Keith-Orpheum Corp., 16 F.R.D. 203, 206 (S.D.N.Y. 1954) (Vague pleading becomes "a springboard . . . into an almost bottomless sea" of discovery in an antitrust case.).

50. See Chicago Council of Lawyers v. Bauer, 522 F.2d 242, 258 (7th Cir. 1975), cert. denied, 427 U.S. 912 (1976); accord, In re Halkin, 598 F.2d 176, 187 (D.C. Cir. 1979). For a criticism of this view, see Marcus, Myth and Reality in Protective Order Litigation, 69 Coruell L. Rev. 1, 29-41 (1983). 
favor of plaintiffs by greatly increasing the stakes and actually impeding disposition on the merits. ${ }^{51}$ Together with pro-plaintiff substantive changes, ${ }^{52}$ themselves fueled by successful discovery forays, ${ }^{53}$ the Rules' procedural innovations appeared to some to leave defendants little meaningful opportunity to prove their innocence on the merits. ${ }^{54}$ The result of this synergy was a litigation industry 55 in which the value

51. Milton Handler, for example, charged that the amended Rule 23 "utilizes the threat of unmanageable and expensive litigation to compel settlement . . . it is a form of legalized blackmail." Handler, The Shift from Substantive to Procedural Innovations in Antitrust Suits-The Twenty-third Annual Antitrust Review, 71 Colum. L. Rev. I, 9 (1971). For a time, there was considerable reason to take this view. By relaxing requirements for rule 23(b)(3) class actions for damages, the 1966 amendments certainly increased the stakes of litigation, and an action arguably was a class action from the date it was filed. Meanwhile, Eisen v. Carlisle \& Jacquelin, 417 U.S. 156 (1974), could be read to forbid consideration of the merits until the court had decided whether to certify a class, a process that could take months or years. But cf. Berry, Ending Substance's Indenture to Procedure: The Imperative for Comprehensive Revision of the Class Damage Action, 80 Colum. L. Rev. 299, 314 (1980) ("Despite [Eisen,] there is pervasive sentiment [among judges and lawyers] favoring some sort of preliminary hearing on the merits."). It should be noted that strictures on precertification merits decisions have been relaxed. See, e.g., Wright v. Schock, 742 F.2d 541 (9th Cir. 1984) (upholding precertification grant of defendant's motion for summary judgment). But class certification is still thought to give plaintiffs a bargaining edge in settlement negotiations. See Note, Certifying Classes and Subclasses in Title V1l Suits, 99 Harv. L. Rev. 619, 626-27 (1986).

52. Examples abound. Bad faith tort claims caused a variety of contract and other commercial disputes to take on new aspects. See, e.g., W. Keeton, D. Dobbs, R. Keeton $\&$ D. Owen, Prosser and Keeton on the Law of Torts 11 (5th ed. 1984) (growth in punitive damages claims for bad faith by insurance companies) [hereinafter cited as Prosser \& Keeton]; Farber, Reassessing the Economic Efficiency of Compensatory Damages for Breach of Contract, 66 Va. L. Rev. 1443, 1468-77 (1980) (arguing for supercompensatory damages in certain situations); Galane, Proving Punitive Damages in Business Tort Litigation, 2 Litig., Spring 1976, at 24, 24 (listing eight business torts in which punitive damages are available). Both compensatory and punitive awards have skyrocketed. See Friedman, The Six Million Dollar Man: Litigation and Rights Consciousness in Modern America, 39 Md. L. Rev. 661, 664-65 (1980).

53. See Friedenthal, supra note 10 , at $818-19 \&$ n.59 (discovery serves to stimulate growth of substantive remedies).

54. See, e.g., infra notes 58-60, 134 and accompanying text. This view is not universal. To the contrary, empirical investigation suggests that the current preoccupation with the litigation "boom" may be an overreaction. See Galanter, supra note 46, at 6I-69. Nevertheless, courts have scen a number of suits that seemed to have no value except as vexation or recreation. Sec, e.g., Hailes v. Equitable Life Assurance Soc'y, 729 F.2d 1037, 1037 (5th Cir. 1984) (employment discrimination claim "the product of a project to obtain a lawsuit-not a secretarial position"); Beachboard v. United States, 727 F.2d 1092, 1095 (Fed. Cir. 1984) ("The unescapable conclusion is that Beachboard is engaged on this appeal in 'recreational' litigation, misusing precious and limited resources better spent on meritorious claims of his fellow citizens . . . ."); Norman v. Reagan, 95 F.R.D. 476, 477 (D. Or. 1982) ("lt is possible, of course, that this is not intended as a claim at all, but as a literary artifact.").

55. Cf. In re Fine Paper Antitrust Litig., 98 F.R.D. 48,72 (E.D. Pa. 1983) (quoting a letter from counsel for plaintiff class referring to "plaintiffs' antitrust industry"), rev'd in part, 75 I F.2d 562 (3d Cir. 1984). 
of litigation appeared only slightly connected to the merits of claims being asserted-a "gigantic slot machine" approach to litigation ${ }^{56}$ in which the status of being a defendant overshadowed the merits of the underlying dispute. ${ }^{57}$

The Supreme Court increasingly has voiced concern about abuse of the litigation process by plaintiffs with groundless claims. In 1975, for example, in Blue Chip Stamps v. Manor Drug Stores, 58 the Court restricted standing to sue for securities fraud because "the liberal discovery provisions of the Federal Rules of Civil Procedure" give plaintiff "an in terrorem increment of the settlement value,"59 so that "even a complaint which by objective standards may have very little chance of success at trial has a settlement value to the plaintiff out of any proportion to its prospect of success at trial so long as he may prevent the suit from being resolved against him by dismissal or summary judgment."60

The same concerns led to pressures to change the Federal Rules

56. Friedenthal, supra note 10 , at 818 (referring to "plaintiffs who sometimes treat the judicial system as if it were a gigantic slot machine").

57. Symptomatic of this trend is the suggestion that the settlement value of meritless litigation is protected by the Sherman Antitrust Act against "conspiracy" by the defendants not to settle. In Lemelson v. United States, 3 Ct. Cl. 161 (1983), aff'd in part, vacated in part, 752 F.2d 1538 (Fed. Cir. 1985), for example, plaintiff sued the United States and two third party defendants for violating plaintiff's patent. After settlement negotiations were unsuccessful, the infringement case went to trial and defendants won. Id. By that time, however, plaintiff had sued the defendants again, alleging that they had violated the antitrust laws by agreeing not to settle the infringement case separately in order to present a common front. See Lemelson v. Bendix Corp., 104 F.R.D. 13 (D. Del. 1984) (discovery motion in same case). The partial vacation and remand of the decision in the infringement case, see Lemelson v. United States, 752 F.2d 1538 (Fed. Cir. 1985), may make the antitrust case seem less extraordinary, but plaintiffs claim was not premised on that. Instead, his premise was that the Sherman Act protected his opportunity to parlay his invalid patent claim into the best possible settlement by playing the defendants off against one another. Eventually, after three years of litigation, the court granted summary judgment to defendants in the antitrust case on the ground plaintiff had insufficient evidence of an illegal conspiracy. See Lemelson v. Bendix Corp., 621 F. Supp. 1122 (D. Del. 1985).

In other contexts, the litigation value of an invalid claim has also been given protection. Thus, in Aloy v. Mash, 38 Cal. 3d 413, 696 P.2d 656, 212 Cal. Rptr. 162 (1985), the court held that failure to assert a claim which was shown by later decisions to be invalid could nonetheless be actionable malpractice. The defendant lawyer had represented plaintiff in her divorce in 1971 and had not then asserted a claim that the husband's military pension was community property. In 1981, the United States Supreme Court decided that states could not award interests in such pensions as community property, so the claim would not have been meritorious. But the California court was unmoved by this fact, reasoning that given the uncertainty of the pre-1981 law, the claim, though now known to be meritless, could then have had litigation value, so that the lawyer could be liable for failure to assert it.

58. 421 U.S. 723 (1975).

59. 1d. at 741 .

60. Id. at 740; see also Reiter v. Sonotone Corp., 442 U.S. 330, 345 (1979) (Courts "must be especially alert to identify frivolous claims brought to extort nuisance settlements."). 
themselves. After extensive debate, the Rules were amended in 1980 and 1983 to promote active case management through pretrial conferences that could "formulate issues" and eliminate "frivolous claims and defenses" and control the conduct and content of discovery. ${ }^{61}$ No longer does Rule 26(a) invite unlimited discovery; the judge is now explicitly authorized to limit discovery that is duplicative or "unduly burdensome or expensive" to protect the parties' right to a reasonably economical decision on the merits. ${ }^{62}$ The amended Rules also place greater emphasis on the duty of lawyers to avoid abuse of litigation by requiring an attorney to investigate both the legal and factual basis of a claim before filing suit, and by promoting increased use of sanctions for violation of various rules. ${ }^{63}$ Courts have begun using sanctions energetically, perhaps too energetically, ${ }^{64}$ to punish those who bring or maintain groundless suits, ${ }^{65}$ an effort that may deter some groundless litigation. ${ }^{66}$ The recent amendments do not, however, abandon the premise that lawsuits should be decided on their merits rather than technicalities.

\section{The Revival of Fact Pleading}

Oh, you might say, we have motions to dismiss-rule 12(b)(6), the vaunted motion to dismiss for failure to state a claim upon which relief can be granted. It is a wonderful tool on paper, but have you ever looked at the batting average of rule

61. Fed. R. Civ. P. 16(c)(1), 26(b), (f). For a review of the 1983 amendments, see Marcus, Reducing Court Costs and Delay: The Potential Impact of the Proposed Amendments to the Federal Rules of Civil Procedure, 66 Judicature 363 (1983). See generally Elliott, Mangerial Judging and the Evolution of Procedure, 53 U. Chi. L. Rev. (forthcoming I986) (managerial judging as an ad hoc method for narrowing issues). For an example of the emphasis on this approach, see United Food \& Commercial Workers v. Armour \& Co., 106 F.R.D. 345, 349 (N.D. Cal. 1985) (endorsing telephone conference to establish baselessness of complaint); cf. Portsmouth Square, Inc. v. Shareholders Protective Comm., 770 F.2d 866, 869 (9th Cir. 1985) (sua sponte grant of summary judgment at final pretrial conference).

62. See Fed. R. Civ. P. 26(b)(1).

63. See Fed. R. Civ. P. 11, 16(f), 26(g); Marcus, supra note 61, at 369-70.

64. Cf. Curtin, Chairman's Corner, 10 Litig. News, Winter 1985, at 2 (reporting views of Professor Arthur Miller that, with respect to sanctions, "the pendulum might swing too far in the other direction" because "judges might impose too many sanctions rather than too few."). In his annual report to the judiciary, however, Chief Justice Burger urged more frequent use of sanctions. Burger Says Vacancies Add to Judicial Deficit, N.Y. Times, Dec. 30,1985 , at 12 , col. 1 .

65. See, e.g., Olympia Co. v. Celotex Corp., 771 F.2d 888, 892-94 (5th Cir. 1985); Eastway Constr. Corp. v. City of New York, 762 F.2d 243, 251-54 (2d Cir. 1985); Huettig \& Schromm, lnc. v. Landscape Contractors Council, 582 F. Supp. 1519 (N.D. Cal. 1984); Van Berkel v. Fox Farm \& Road Mach., 581 F. Supp. 1248 (D. Minn. 1984).

66. See, e.g., Conard, Winnowing Derivative Suits Through Attorneys leces, 47 law \& Contemp. Probs., Winter 1984, at 269, 284-85; Rowe, Predicting the Ellects of Attorney Fee Shifting, 47 Law \& Contemp. Probs., Winter 1984, at 139, 161. 
12(b)(6) motions? I think it was last effectively used during the McKinley administration.

\section{Professor Arthur R. Miller67}

Amidst the tumult surrounding the litigation boom, there has been almost no talk of changing the Federal Rules of Civil Procedure governing pleading. ${ }^{68}$ The last serious proposal was in the early $1950 \mathrm{~s}$, when the Ninth Circuit, in what has been described as a "guerrilla attack" 69 on simplified pleading, urged that Rule 8(a)(2) be amended to revive code pleading by requiring the plaintiff to allege "the facts constituting a cause of action."70 During the same period, several district judges in the Southern District of New York were engaged in what Clark himself characterized as "something bordering on a revolt" against the existing rule. ${ }^{71}$ The Advisory Committee on the Civil Rules rejected the proposed change, ${ }^{72}$ and Conley $v$. Gibson seemed to scotch the effort to revert to code practice.

Undoubtedly, lax pleading has, like the procedural and substantive changes discussed above, ${ }^{73}$ benefitted plaintiffs. Plaintiffs have an incentive to plead vaguely in hopes that discovery will turu up material on

67. A. Miller, The August 1983 Amendments to the Federal Rules of Civil Procedure: Promoting Effective Case Management and Lawyer Responsibility 7-8 (1984).

68. E.g., National Commission Staff Paper, The Early Narrowing and Resolution of Issues, 48 Antitrust L.J. 1041, 1056 (1980) ("There has been little testimony or comment presented to the [National] Commission [for Review of the Antitrust Laws] favoring increased specificity in antitrust pleadings.") (footnote omitted).

69. R. Field, B. Kaplan \& K. Clermont, Materials For a Basic Course in Civil Procedure 439 (5th ed. 1984).

70. See Claim or Cause of Action: A Discussion on the Need for Amendment of Rule 8(a)(2) of the Federal Rules of Civil Procedure, 13 F.R.D. 253, 253 (1952).

71. Clark, Special Pleading in the "Big Case," 21 F.R.D. 45, 49 (1957). These judges began in the early 1950 s to insist on more specific pleadings in large cases, particularly antitrust cases. See Baim \& Blank, Inc. v. Warren-Connelly Co., 19 F.R.D. 108, 109-10 (S.D.N.Y. 1956). In Nagler v. Admiral Corp., 248 F.2d 319 (2d Cir. 1957), the Second Circuit, speaking through Chief Judge Clark, rejected this movement: "[I]t is quite clear that the federal rules contain no special exceptions for antitrust cases." Id. at 322-23.

Coupled with the Supreme Court's pronouncement the same year in Conley v. Gibson, 355 U.S. 41 (1957), Nagler ended the debate in the courts, but the participants continued it elsewhere. Thus, Judge Dawson, the author of Baim $\varepsilon^{2}$ Blank, Inc., later commented: "The anti-trust bar was beginning to understand the necessity for this type of pleading in those cases . . . until Judge Clark made his speech at the Seminar [on Protracted Cases] last year and then followed it up with his decision in Nagler v. Admiral Corporation . . . Dawson, The Place of the Pleading in the Proper Definition of the lssues in the "Big Case," 23 F.R.D. 430, 434 (1958). Clark responded to "Judge Dawson's slashing attack" in Clark, Comment on Judge Dawson's Paper on the Place of the Pleading in the Proper Definition of the Issues in the "Big Case," 23 F.R.D. 435 (1958).

72. See Report of Proposed Amendments to the Rules of Civil Procedure for the United States District Courts 18-19 (1955) (explaining decision not to modify Rule $8(a)(2))$.

73. See supra notes $49-54$ and accompanying text. 
which to base a more specific charge. ${ }^{74}$ Indeed, it has even been suggested that specificity inherently favors defendants. ${ }^{75}$ Moreover, under Conley $v$. Gibson courts may be inclined to deny motions to dismiss precisely because they cannot tell enough about a plaintiff's claim from the pleadings to decide whether the plaintiff has a chance of prevailing at trial. As the Supreme Court noted in Blue Chip Stamps, ${ }^{76}$ plaintiffs with weak claims have good reason to want to stave off dismissal in hopes of a settlement.

A natural antidote to pro-plaintiff biases and the impulse toward vagueness is to promote pleadings decisions, and the courts have adopted this solution in areas that were viewed as particularly troubling. The Supreme Court itself, while approaching pleading issues with what has been called "appalling casualness" 77 and continuing outwardly to adhere to Conley, ${ }^{78}$ has nevertheless provided some support for such creativity. It has suggested that "insubstantial" cases can be dismissed despite "artful pleading"79 and appeared receptive to using pleading motions to weed out meritless cases. In a I983 decision reversing dismissal of an antitrust case, for example, it exhorted the district court to require plaintiff to plead with particularity, concluding that "in a case of this magnitude, a district court must retain the power to insist upon some specificity in pleading before allowing a potentially massive factual controversy to proceed." 80

Perhaps taking its own advice about the value of specificity, the Court has relied increasingly on fact pleading to resolve standing issues. In a 1975 decision, for example, the Court rejected plaintiffs' standing allegations as "conjectural" and "conclusory."81 Such allega-

74. Judges are not oblivious to this tendency toward vagueness. See, e.g., Levitch v. Columbia Broadcasting Sys., 94 F.R.D. 292, 294 (S.D.N.Y. 1982) (dismissing amended complaint characterized as "an effort [by plaintiffs] to keep their claim as ambiguous as possible"), aff d, 697 F.2d 495 (2d Cir. 1983); Weinstein, Proposed Revision of New York Civil Practice, 60 Colum. L. Rev. 50, 72 (1960) ("[T]he federal rules provide no protection against the unskilled and the skillful obscurers."). Clark certainly had no intention of fostering a shift to vagueness. See C. Clark, supra note 31, § 41, at 253 ("[W]e should not put a premium upon ignorance, so that the pleader who knows the least about his case will be the most protected by his pleading.").

75. See Friedenthal, supra note 10 , at 815 . On the other hand, it may be that defendants resist more vigorously when plaintiffs allegations are vague. See Kingdon, The "Big Antitrust Case": Thoughts on Procedural Reform, 37 Wash. \& Lee L. Rev. 25, 38 (1980); cf. Brazil, Kahn, Newman \& Gold, Early Neutral Evaluation: An Experimental Effort to Expedite Dispute Resolution, 69 Judicature 279, 279 (1986) (notice pleading makes early settlement difficult because true center of dispute cannot be identified).

76. Blue Chip Stamps v. Manor Drug Stores, 421 U.S. 723 (1975); see supra notes 58-60 and accompanying text.

77. Roberts, supra note 12 , at 399 .

78. See, e.g., Hishon v. King \& Spalding, 104 S. Ct. 2229, 2233 (1984).

79. Butz v. Economou, 438 U.S. 478, 507 (1978) (dictum).

80. Associated Gen. Contractors, lnc. v. California State Council of Carpenters, 459 U.S. 519,528 n.17 (1983) (dictum).

81. Warth v. Seldin, 422 U.S. $490,503,509$ (1975). 
tions were insufficient, the Court explained without reference to Conley v. Gibson, because they were not supported by "particularized allegations of fact" and "specific, concrete facts" showing harm to plaintiffs. ${ }^{82}$

Many lower courts have been even more vigorous in insisting on fact pleading. Although special pleading rules are sometimes used to accomplish a narrow policy objective, ${ }^{83}$ these decisions generally fit into one of three categories.

1. Securities Fraud. - Virtually unknown when the Federal Rules were adopted, ${ }^{84}$ securities fraud cases have since proliferated. Many courts have responded by requiring plaintiffs to plead detailed facts. To some extent this insistence can be justified by the special pleading requirements of Rule $9(\mathrm{~b})$, which requires that in fraud cases "the circumstances constituting fraud . . . shall be stated with particularity." 85 Clark, who viewed this Rule as a compromise with judges' habits, said it "probably states only what courts would do anyhow." 86 The Rule does not overturn the general thrust of the Federal Rules to avoid pleading battles and promote decisions on the merits in their place. ${ }^{87}$

82. Id. at 501, 508. Two years earlier, the Court had shown a preference for deferring standing decisions until the summary judgment stage. See United States v. Students Challenging Regulatory Agency Procedures (SCRAP), 412 U.S. 669, 689-90 (1973). For a criticism of the use of pleading to resolve standing issues, see Roberts, supra note 12.

83. The Ninth Circuit adopted a special pleading rule in cases involving activity arguably protected by the first amendment. See Franchise Realty Interstate Corp. v. San Francisco Local Joint Executive Board of Culinary Workers, 542 F.2d 1076, 1083 (9th Cir. 1976) ("[T]he danger that the mere pendency of the action will chill the exercise of First Amendment rights requires more specific allegations than would otherwise be required."), cert. denied, 430 U.S. 940 (1977). Arguably, this insistence on greater specificity in pleading to protect first amendment interests should be reexamined in light of Calder v. Jones, 465 U.S. 783, 790-91 (1984) (rejecting argument that first amendment concerns should limit scope of personal jurisdiction), and Herbert v. Lando, 441 U.S. 153 (1979) (rejecting argument that first amendment provides basis for privilege against discovery into editorial process in libel action).

84. The first case recognizing a private cause of action for damages under rule 10b5 was Kardon v. National Gypsum Co., 69 F. Supp. 512 (E.D. Pa. I946).

85. Fed. R. Civ. P. 9(b).

86. Clark, Simplified Pleading, 2 F.R.D. 456, 463 (1943).

87. The commentators have roundly rejected the formalistic argument that rule 9(b) erects a special regime immune to the liberal pleading approach of rule 8. E.g., 5 C. Wright \& A. Miller, supra note $3, \S 1298$, at 406 (rule 9(b) must be read in conjunction with rule 8); 2A Moore's Federal Practice, supra note 40, If 9.03, at 9-28 (same). Even the Second Circuit, most active in expansive use of rule $9(\mathrm{~b})$, has on occasion recognized this. See Felton v. Walston \& Co., 508 F.2d 577, 581 (2d Cir. 1974) ("'[I]n applying rule $9(\mathrm{~b})$ we must not lose sight of the fact that it must be reconciled with rule 8 . . . "). Moreover, the actual emphasis in many cases on detailed evidence supporting allegations about the defendant's state of mind, see infra notes 90-93 and accompanying text, is forbidden by the second sentence of rule $9(\mathrm{~b})$, which explicitly permits general pleadings to state of mind. See infra note 216 and accompanying text.

Nor is the use of rule $9(\mathrm{~b})$ to permit expansive pleadings decisious justified on policy grounds. First, the disfavored claims idea, which is one historical antecedent of rule 
Consistent with the general purposes of the Rules, some courts find that Rule 9(b) is designed to provide somewhat more specific notice and that it requires only "slightly more" detail than Rule 8(a)(2). ${ }^{88}$ However, other courts, particularly the Second Circuit, find that Rule 9(b) serves a much more substantive purpose-to protect defendants' reputations from unfounded claims of fraud and to assure that such malodorous claims are not filed as a pretext for discovery: "It is a serious matter to charge a person with fraud and hence no one is permitted to do so unless he is in a position and is willing to put himself on record as to what the alleged fraud consists of specifically." "Bo

The stricter courts pay great attention to "conclusory" allegations about defendants' knowledge or intent. Some hold that plaintiffs may not rely on allegations based on information and belief. ${ }^{90}$ Some insist that the plaintiff provide specific details that support factual conclusions. For example, in Ross v. A.H. Robins Co., ${ }^{91}$ plaintiff shareholders sued the company and its senior officers. Plaintiffs claimed that the defendants had knowingly or recklessly failed to disclose the health risks caused by use of the Dalkon Shield intrauterine device that eventually resulted in the filing of hundreds of lawsuits against Robins, with total claims far exeeding Robins' net worth. ${ }^{92}$ In their complaint, plaintiffs, who bought their shares in 1973, alleged that Robins had then touted the device as a boost to the company's financial health even though in

9(b), see 5 C. Wright \& A. Miller, supra note $3, \S 1296$, at 400 , simply fails to justify the new fact pleading. See infra notes 228-38 and accompanying text. Second, the courts' effort to erect special protections against charges of fraud, see infra note 89 and accompanying text, does not explain why fraud should be treated differently from other claims such as racketeering, racial discrimination, price-fixing, and environmental pollution, for which there are no special pleading rules. See infra notes 237-38 and accompanying text. Finally, and most importantly, in many cases fact pleading provides no reliable mechanism for evaluating a plaintiff's factual conclusions. Fact pleading therefore threatens the objectives of promoting reliable decisions on the merits and avoiding pleading battles. See infra notes 196-227 and accompanying text. Both from the perspective of the rules governing pleading and more generally in terms of the overall purpose of the rules, then, the presence of special pleading provisions does not justify the new fact pleading even in the area of fraud.

88. Sec, e.g., Tomera v. Galt, 511 F.2d 504, 508 (7th Cir. 1975); cf. Walling v. Beverly Enter., 476 F.2d 393, 397 (9th Cir. 1973) (Rule 9(b) only requires that circumstances constituting fraud be pleaded with sufficient particularity so that defendant can prepare an answer, and does not require pleading of detailed evidentiary matters.).

89. Segal v. Gordon, 467 F.2d 602, 607 (2d Cir. 1972) (quoting 1A W. Barron \& A. Hotzhoff, Federal Practice and Procedure $\S 302$, at 215-16 (Wright rev. 1960)); see also Billard v. Rockwell Int'l Corp., 683 F.2d 51, 57 (2d Cir. 1982) (Rule 9(b) construed strictly to minimize strike suits). For criticism of this use of Rule 9(b), see Sovern, supra note 12 , at $165-71$; Note, supra note 12 , at $1439-47$.

90. See, e.g., Wayne Inv., Inc. v. Gulf Oil Corp., 739 F.2d 11, 13-14 (1st Cir. 1984); Duane v. Altenburg, 297 F.2d 515, 518-19 (7th Cir. 1962).

91. 607 F.2d 545 (2d Cir. 1979), cert. denied, 446 U.S. 946 (1980).

92. In fact, Robins has recently sought protection from these suits by filing a petition under Chapter 11 of the Bankruptcy Code. See Robins Files for l'rotection of Chapter 11, Wall St. J., Aug. 22, 1985, at 3, col. 1. 
May, 1974, the company wrote 120,000 doctors across the country warning them of health hazards associated with the use of the device. To bolster their claim that defendants had known or recklessly disregarded these risks prior to plaintiffs' purchase of their shares in 1973, plaintiffs pointed to an unpublished 1972 study detailing the health hazards associated with the Dalkon Shield. Because plaintiffs did not allege Robins was aware of the study, however, the Second Circuit found the complaint inadequate for failure to "specifically plead those events which they assert give rise to a strong inference that defendants had knowledge of the facts." 93

2. Civil Rights Cases. - Like securities fraud cases, civil rights suits have since 1938 become a staple of the federal courts' civil docket. Unlike securities fraud cases, however, there is no special provision of the Federal Rules applicable to civil rights claims. Many lower federal courts have nevertheless revived fact pleading requirements in such cases.

The leader in this movement has been the Third Circuit, which is forthright about its motivation: "In recent years there has been an increasingly large volume of cases brought under the Civil Rights Act. . . . It is an important public policy to weed out the frivolous and insubstantial cases at an early stage in the litigation ...." "94 To achieve this objective most courts now declare that conclusory allegations are inadequate to state a civil rights claim. They require specific delineation of the facts claimed to show a violation of plaintiff's civil rights $^{95}$ and, as in securities fraud cases, focus particularly on plaintiff's allegations about intent. ${ }^{96}$

These requirements have been applied with remarkable enthusiasm. In United States $v$. City of Philadelphia, ${ }^{97}$ for example, the Department of Justice filed a complaint alleging in part that the Philadelphia police department systematically violated the civil rights of minority persons by abusing them physically. The complaint was signed by several government lawyers, including the Attorney General.98 Citing, among other things, the potential that such a claim could be vexatious to local police officials, the trial court dismissed. ${ }^{99}$ Although it specifically disavowed any need to determine whether the claim was frivo-

93. 607 F.2d at 558.

94. Rotolo v. Borough of Charleroi, 532 F.2d 920, 922 (3d Cir. 1976) (quoting Valley v. Maule, 297 F. Supp. 958, 960 (D. Conn. 1968)).

95. See, e.g., Jones v. Community Redevelopment Agency, 733 F.2d 646, 649 (9th Cir. 1984). See generally Roberts, supra note 12, at 417-19 (canvassing civil rights pleading cases).

96. See, e.g., Albany Welfare Rights Org. Day Care Center, Inc. v. Schreck, 463 F.2d 620, 623 (2d Cir. 1972) (upholding dismissal for failure adequately to allege defendant's motivation), cert. denied, 410 U.S. 944 (1973).

97. 644 F.2d 187 (3d Cir. 1980).

98. Id. at 205.

99. 482 F. Supp. 1274, 1278 (E.D. Pa. 1979), aff'd, 644 F.2d 187 (3d Cir. 1980). 
lous, ${ }^{100}$ the Third Circuit affirmed on the ground that the complaint did not satisfy the specificity requirement for civil rights cases, which it said was necessary to provide "fair notice" and to dispose of frivolous cases. ${ }^{101}$

3. Conspiracy. - Concerns about conspiracy seem pervasive today, and many plaintiffs include conspiracy allegations in their complaints. As Heart Disease Research Foundation v. Ceneral Motors Corp. ${ }^{102}$ shows, the lower courts also scrutinize conspiracy allegations with care. In general, they say that broad, vague charges of conspiracy do not suffice. ${ }^{103}$ Some require, at a minimum, that the plaintiff enumerate the overt acts alleged to show that the conspiracy existed. ${ }^{104}$

4. Summary: The Persistent Themes. - The situations in which the new fact pleading has been applied possess siguificant common characteristics. For one, they represent important segments of activity in the litigation boom, each type of claim having experienced enormous growth since the Federal Rules were adopted. ${ }^{105}$ More significantly, however, these situations present particularly difficult problems involving the potential abuse of litigation because they often involve outwardly innocent or admitted behavior that can, depending on the defendant's state of mind, result in very substantial liability. In a typical securities case, for example, the dispute is not over the content of the representations made by the defendants, but rather whether those representations were inaccurate and, if inaccurate, whether defendants knew or should have known of such inaccuracy. In the paradigmatic employee's civil rights suit, the dispute is not over whether defendants have fired the plaintiff, but rather their motivation for doing so. In many antitrust cases, the dispute is not over what happened to the

100. 644 F.2d at 205 n.28; cf. P. Marcus, The Big Antitrust Case in the Trial Courts, 37 Ind. L.J. 51, 61 (1961) ("The writer is not aware of the filing of a government antitrust suit where there was not sufficient knowledge of facts to warrant an honest belief that a violation of the Sherman Act existed.") (emphasis added).

101. 1d. at 205-06. In view of the change of administration in Philadelphia (Mayor Rizzo was replaced) and the imminent change of administrations in Washington, the Carter administration decided not to seek Supreme Court review. See O. Fiss \& D. Rendleman, Injunctions 56 (2d ed. 1984).

102. 463 F.2d 98 (2d Cir. 1972); see supra text accompanying notes 13-18.

103. See, e.g., Fullman v. Graddick, 739 F.2d 553, 557 (11th Cir. 1984); California Dump Truck Owners Assoc., Inc. v. Associated Gen. Contractors, 562 F.2d 607, 615 (9th Cir. 1977); Burnett v. Short, 441 F.2d 405, 406 (5th Cir. 1971). But see Quinones v. Szorc, 771 F.2d 289, 291 (7th Cir. 1985); Hoffman v. Halden, 268 F.2d 280, 294-95 (9th Cir. 1959) ("Hoffman also alleges the 'defendants conspired.' In what other way can plaintiff plead conspiracy? . . He should not be required here to plead his evidence.").

104. See Powell v. Workmen's Compensation Bd., 327 F.2d 131, 137 (2d Cir. 1964), and cases cited therein.

105. This is not to say that strict fact pleading requirements were unknown in such cases before the 1960s. See, e.g., Dunn v. Gazzola, 216 F.2d 709, 711 (1st Cir. 1954) (rejecting allegation of conspiracy not supported by facts); Connor v. Real Title Corp., I65 F.2d 291, 294 (4th Cir. 1947) (same). 
plaintiff, but rather whether whatever happened resulted from an agreement or conspiracy among the defendants. Given the breadth of potential discovery on issues like intention and knowledge, it is understandable that some courts have attempted to weed out groundless cases at the outset.

\section{Notice Pleading}

Whatever the earlier function of pleadings, the stated modern justification is limited to notice. Conley $v$. Gibson ${ }^{106}$ itself appeared to endorse the notice pleading idea, ${ }^{107}$ which the Supreme Court had previously suggested was the sole purpose of pleadings. ${ }^{108}$ Since Conley, the received learning has been that the function of pleadings is to give notice. ${ }^{109}$ Even where Rule 9 (b)'s particularity requirement applies, some courts routinely deny pleading motions if they believe defendant has sufficient notice to prepare an answer, ${ }^{110}$ sometimes even though the complaint itself fails to provide notice. ${ }^{111}$ According to this approach, defendant's desire for further information about plaintiff's claims should be handled later through discovery and other pretrial procedures. ${ }^{112}$

But notice pleading is a chimera. Within a year after Conley, Clark himself described it as "something like the Golden Rule, which is a nice hopeful thing; but . . . isn't anything that we can use with any precision." 13 More fundamentally, one may ask why it should be used at

106. 355 U.S. $41,47-48$ (1957).

107. See id. (referring to "simplified 'notice pleading' [that] is made possible by the liberal opportunity for discovery and the other pretrial procedures established by the Rules to disclose more precisely the basis of both claim and defense and to define more narrowly the disputed facts and issues") (footnote omitted).

108. See Hickman v. Taylor, 329 U.S. 495, 501 (1947) (Federal Rules "restrict the pleadings to the task of general notice-giving.").

109. See supra note 40 and accompanying text.

110. See, e.g., Bosse v. Crowell, Collier \& Macmillan, 565 F.2d 602, 611 (9th Cir. 1977) ("Rule 9(b) . . . only requires the identification of the circumstances constituting fraud so that the defendant can prepare an adequate answer from the allegations ....").

111. See, e.g., In re Commonwealth Oil/Tesoro Petroleum Corp. Sec. Litig., 467 F. Supp. 227, 251 (W.D. Tex. 1979) (Rule 9(b) does not "require plaintiffs repeatedly to redraft pleadings" when the defendants have "pre-existing full knowledge of the matters which plaintiffs' pleading addresses. Therefore, . . . even though plaintiffs' pleadings are vague, [where] the defendants do in fact have notice of the matters of which plaintiffs complain, a strict application of Rule 9(b) can serve no purpose."); cf. Whittier, Notice Pleading, 31 Harv. L. Rev. 501, 505 (1918) (" $[\mathrm{I}] \mathrm{f}$ the opponent does understand the pleader's claim, whether that be the result of the pleading itself or partly due to the opponent's own knowledge, he is obviously not entitled to particulars."). How the court is to determine whether the defendant has sufficient knowledge indepedent of the pleadings, however, is something of a mystery.

112. See C. Wright, The Law of the Federal Courts § 68, at 439 (4th ed. 1983); supra note 107.

1 I3. Clark, Pleading Under the Federal Rules, I2 Wyo. L.J. 177, 18I (1958). Some 
all. Providing notice would seem, after all, to be the function of a motion for a more definite statement under Rule 12(e), which is allowed when a pleading "is so vague or ambiguous that a party cannot reasonably be required to frame a responsive pleading."114 But a defendant hardly needs specificity to deny a vague allegation, ${ }^{115}$ and will rarely be unable to raise a legitimate affirmative defense due to vagueness of the pleadings. To take a common example, defendants can preserve statute of limitations defenses by alleging in their answers that plaintiffs' claims are barred, in whole or in part, by limitations. ${ }^{116}$ Moreover, if ambiguity of pleadings has obscured an affirmative defense, courts will rarely refuse an amendment to add the defense once discovery has shown it to be applicable. ${ }^{117}$ Accordingly, it would seem that the defendant always has enough notice to be able to prepare an answer.

More detailed pleadings are similarly unimportant in relation to other pretrial activities. Although they may pinpoint an opposing party's view of the facts somewhat, they are hardly substitutes for examination by deposition. Moreover, as the opposing party obtains more information through discovery, his view of the facts is likely to evolve. In practice, discovery itself is often difficult to limit to specific factual allegations, and the liberal amendment provisions of the Rules would be undermined by efforts to imprison the plaintiff within detailed initial assertions.

Balanced against the marginal utility of more detailed notice ${ }^{18}$ is

have suggested, however, that these views represent something of a political retreat by Clark, not a modification of his basic view. See Smith, supra note 3, at 925-26.

114. Fed. R. Civ. P. 12(e).

115. It is true that Fed. R. Civ. P. 8(b) imposes a good faith requirement not to deny matters known to be true, but it also says that where the pleader "is without knowledge or information sufficient to form a belief as to the truth of an averment, he shall so state and this has the effect of a denial." As a general matter, then, where the defendant is uncertain about the law or the facts on which the plaintiff relies, it may deny. See Shultz v. Manor House of Madison, Inc., 51 F.R.D. 16, 17-18 (W.D. Wis. 1970).

116. See 2A Moore's Federal Practice, supra note 40, I 12.18, at 12-145 to 12-146.

117. Fed. R. Civ. P. 15(a) directs that leave to amend be "freely given." The Supreme Court has indicated this means amendment should be allowed in the absence of bad faith or undue delay by the moving party. See Foman v. Davis, 371 U.S. 178, 182 (1962); see also supra note 42 and accompanying text. This same liberality applies to amendments of answers to add affirmative defenses. See, e.g., Glater v. Eli Lilly \& Co., 712 F.2d 735, 738-39 (1st Cir. 1983).

118. For a recent example of the minimal importance the Supreme Court attaches to notice in other contexts, consider Brandon v. Holt, 105 S. Ct. 873 (1985). Plaintiffs, injured by a policeman, sued the director of the police department for failure to fire the officer for previous misconduct. Although plaintiffs obtained a judgment, the court of appeals reversed on the ground that the director was protected by qualified immunity because he was not personally aware of the officer's tendencies and thus was acting in good faith.

The Supreme Court reversed, holding that a judgment against a public servant in his official capacity imposes liability on the entity he represents. The Court held that judgment should be entered against the city itself because even though the city had never been named as a defendant it could be added under Rule 15(b) as an amendment 
the substantial cost of pleading practice designed to elicit additional details. Dilatory motions remain a problem, ${ }^{119}$ and motions seeking an emendation of the complaint seem peculiarly susceptible to abuse due to their potential for delay. For example, in Ross v. A.H. Robins Co. ${ }^{120}$ while the Second Circuit faulted plaintiff's pending complaint for lacking facts "strongly supporting" the inference defendants knew about the dangers of the Dalkon Shield, it also remanded to give them another chance to do so. They evidently succeeded, and the case remained on the district court's docket for at least another four years. ${ }^{121}$ Neither the early motion practice nor the appeal seem to have advanced the case meaningfully toward ultimate resolution.

This is not to say either that specifics and precision are undesirable, or that no complaints are so opaque that redrafting is necessary in order to apprise the defendant of the nature of the plaintiff's grievance. ${ }^{122}$ In general, however, pleading motions are unlikely to advance the litigation process in a meaningful way unless they provide some hope of leading to a resolution of the case on the merits. Early resolution on the merits is the objective of the Rule 12(b)(6) motion to dismiss for failure to state a claim. The 12(b)(6) motion should not be diluted into a variant of the motion for a more definite statement. ${ }^{123}$ Indeed, some courts use the more definite statement to expose defects in the claim that would permit dismissal. ${ }^{124}$ To require the courts to approach this objective indirectly, using the language of notice plead-

to conform to proof. Id. at 877-78. Justice Rehnquist dissented on the ground that Rule 15(b) had not been satisfied by plaintiffs' one-sentence reference to amendment in their reply brief to the Supreme Court. Id. at 879 . Chief Justice Burger concurred in the judgment, noting: "[M]odern pleading is less rigid than in an earlier day, but it is not too much to ask that if a person or entity is to be subject to suit, the person or entity should be named. I agree with Justice Rehnquist that it is a dubious business to encourage such shoddy pleading practices, but the courts have crossed that bridge." Id.

I19. See Edelstein, The Ethics of Dilatory Motion Prctice: Time for Change, 44 Fordham L. Rev. 1069 (1976).

120. 607 F.2d 545 (2d Cir. 1979), cert. denied, 446 U.S. 946 (1980); see supra notes $91-93$ and accompanying text.

121. See Ross v. A.H. Robins Co., [1982-83 Transfer Binder] Fed. Sec. L. Rep. (CCH) \ 99,095 (S.D.N.Y. Feb. 14, 1983).

122. See, e.g., Mountain View Pharmacy v. Abbott Laboratories, 630 F.2d 1383, 1386-87 (10th Cir. 1980) (In a complex case, more details are necessary.).

123. See 5 C. Wright \& A. Miller, supra note $3, \S 1376$, at $732-34$ (motion for more definite statement is limited to a "quite small" class of cases in which court can discern a viable claim but the complaint is still "so vague or ambiguous that the opposing party cannot respond, even with a simple denial, in good faith and without prejudice to himself') (footnote omitted). As indicated supra notes 115-17 and accompanying text, it is doubtful any such cases really exist. At most, as Professors Wright and Miller conclude, the motion for a more definite statement "should be strictly limited to those few instances in which a significant advancement of the litigation will result." $5 \mathrm{C}$. Wright \& $\mathrm{A}$. Miller, supra note 3 , § 1376 , at 747 .

124. See 5 C. Wright \& A. Miller, supra note $3, \S 1376$, at 743-44 (discussing use of more definite statement to permit disposition on grounds of statute of limitations or Statute of Frauds); id. $\$ 1217$, at 131 (" $[\mathrm{C}]$ ourts often will use a motion directed at the 
ing, ${ }^{125}$ either obscures or deflects the proper inquiry. Moreover, once sufficient details are included to show that a legitimate claim has been stated, any notice objective should also have been satisfied. ${ }^{126}$ Notice should not be the sole, or even the principal, objective of pleadings practice. The proper focus should shift to merits dispositions.

\section{Merits Decisions}

Under the received tradition, the problem with common law pleading practice was that, while it led to actual decisions, it often did not lead to merits decisions because cases were frequently resolved on technicalities. The notice pleading scenario, by way of contrast, eliminates the possibility for even genuine merits decisions at the pleadings stage. The middle ground is to use pleading practice to make genuine and reliable merits decisions. Contrary to expectation, this activity is not dead, though it is often camouflaged in notice pleading language.

This Part examines the contemporary use of pleadings to decide cases on the merits, which is the ultimate effect of revived fact pleading. It begins by examining the key question: whether decisions at the pleading stage are to be preferred to settlements, which occur in most cases that are not dismissed before trial. Finding that such decisions are desirable in the abstract to achieve the objectives of the substantive law, it then explores situations where pleading practice can effectively resolve the merits-where legal conclusions relied on by the plaintiff can be shown to be groundless by requiring more factual detail in pleading. Finally, this Part explores the problem of scrutinzing plaintiff's factual conclusions, which is the focus of much of the new emphasis on fact pleading, and finds that this problem cannot sensibly be handled at the pleading stage. Accordingly, although merits resolution by pleading motion may in many cases be possible, it appears ill-suited for the kinds of cases in which the courts have been using fact pleading as an antidote to the ills of the litigation boom.

\section{A. Merits Decision Versus Settlement}

Most cases are never resolved by a court, on the merits or otherwise, because they are settled. ${ }^{127}$ Recently this statistic has kindled a

form of a pleading as a vehicle for considering whether any possible claim for rclief exists.").

125. See, e.g., Hayduk v. Lanna, 775 F.2d 441, 444 (1st Cir. 1985) (absencc of facts supporting claim that defendants conspired to defraud plaintiff deprives defendants of notice of basis of claims against them). See generally $5 \mathrm{C}$. Wright \& A. Miller, supra note $3, \S 1217$, at 131 (Courts use motions directed to the form of a complaint to determine whether any claim for relief exists.).

126. See supra notes 115-17 and accompanying text. Accordingly, some advocate eliminating the motion for a more definite statement altogether, leaving discovery to clarify vague claims. See 5 C. Wright \& A. Miller, supra note $3, \S 1376$, at 740 \& n.50.

127. This statistic is hardly new. Clark observed in 1935 that only $30 \%$ of federal 
debate between the proponents of the "dispute resolution" model of litigation and the advocates of the "public interest" model. Imported into the pleading practice area, the debate identifies the underlying issues.

Proponents of the public interest model oppose viewing the court system primarily as a lever or facilitator for essentially private dispute resolution. To some, this means that any resolution of a lawsuit except by judicial decision represents a failure of the judicial system. Professor Owen Fiss, a leading light in this camp, explains that " $[t] 0$ be against settlement is only to suggest that when the parties settle, society gets less than what appears, and for a price it does not know it is paying. Parties might settle while leaving justice undone."128 Although the proponents of the public interest view seem generally to have in mind a decision after a full dress trial, the reasoning appears to apply equally to pretrial judicial decisions, including pleading dispositions. Indeed, given the impossibility of actually trying all civil cases, logic seems to favor pretrial disposition.

The dispute resolution advocates, on the other hand, mistrust judicial resolution. Even judges openly question the desirability of complete resolution after trial as the generally preferred outcome. As one experienced federal judge put it in a seminar for new judges, "[o]ptimal justice is usually found somewhere between the polar positions of the litigants. Trial is likely to produce a polar solution, and often the jury or the judge has no choice except all or nothing. Settlement is usually the avenue that allows a more just result than trial."129

court civil cases then reached a court decision. Clark \& Moore, A New Federal Civil Procedure: Pleadings and Parties (pt. 2), 44 Yale L.J. 1291, 1294 \& n.8 (1935); cf. Galanter, The Emergence of the Judge as a Mediator in Civil Cases, 69 Judicature 256, 257 (1986) ("1t remains unclear whether the percentage of cases terminated by settlement has increased in recent years.").

128. Fiss, Against Settlement, 93 Yale L.J. 1073, 1085 (1984). He explains further:

I do not believe that settlement as a generic practice is preferable to judgment or should be institutionalized on a wholesale and indiscriminate basis. It should be treated instead as a highly problematic technique for streamlining dockets. Settlement is for me the civil analogue of plea bargaining . . . . Like plea bargaining, settlement is a capitulation to the conditions of mass society and should be neither encouraged nor praised.

Id. at 1075. Professor Fiss is generally opposed to treating courts primarily as dispute resolution forums. See Fiss, The Supreme Court, 1978 Term-Foreword: The Forms of Justice, 93 Harv. L. Rev. 1, 29 (1979) ("[C]ourts exist to give meaning to our public values, not to resolve disputes."). Despite Fiss' arguments, all plea bargaining need not be viewed as a failure of the judicial system. For an argument that the only constitutional concern with plea bargaining is that the innocent will plead guilty, see McCoy \& Mirra, Plea Bargaining as Due Process in Determining Guilt, 32 Stan. L. Rev. 887, 921-22 (1980). Similar concerns bear on the undesireability of settlements in civil cases. See infra notes 133-39 and accompanying text.

129. Tone, The Role of the Judge in the Settlement Process, in Seminars for Newly Appointed United States District Judges 57, 60 (1975); accord Coons. Approaches to Court Imposed Compromise-The Uses of Doubt and Reason, 58 Nw. U.L. Rev. 750. 
This view evinces great skepticism about the liberal ethos and its preference for judicial resolution on the merits. Instead, a settlement may be preferable, whatever the ultimate merits of the claim, ${ }^{130}$ so long as the plaintiff "firmly believes" he has a legitimate grievance against defendant. ${ }^{131}$ Arguably, then, dismissal on the pleadings would not be a desirable alternative. ${ }^{132}$

Thus, the two schools pose the core problem: Are pleadings decisions or settlements better? Denial of a motion to dismiss often means only that a defendant who will ultimately prevail must litigate longer. Even the confident defendant may decide to settle, however. To the extent that decision is made "in the shadow of the law" because it reflects a prediction of the substantive merits of the case, ${ }^{133}$ it accomplishes the objectives of the substantive law, albeit in a modified form because a settlement is not an "all or nothing" result. Freed of the burden of deciding the settled case, the court system is able to turn its attention to other cases, and there apply the substantive law.

The settlement model breaks down, however, when the defendant's payment to the plaintiff is based mainly on factors other than the substantive merits of the suit. ${ }^{134}$ This is the spectre which haunts the

751 (1964) (seeing the "judicial power to compromise between the often harsh alternatives of all-or-nothing" as promoting a "fair" decision that is unattainable by law).

130. Cf. Marek v. Chesny, 105 S. Ct. 3012, 3018 (1985) ("Rule 68's policy of encouraging settlements is neutral, favoring neither plaintiffs nor defendants; it expresses a clear policy of favoring settlement of all lawsuits.").

131. The phrase comes from Clark's famous opinion reversing a dismissal in Dioguardi v. Durning, 139 F.2d 774, 775 (2d Cir. 1944).

132. To some extent this preference for a negotiated over a judicial resolution is confirmed by the handling of prisoner cases, where the courts act because they have to. "Relatively few prison cases can be settled, primarily because meaningful negotiations between prisoners acting pro se and states' attorneys are practically impossible. Thus, unlike other civil litigation, some court action is required on almost all the cases." Turner, When Prisoners Sue: A Study of Prisoner Section 1983 Suits in the Federal Courts, 92 Harv. L. Rev. 610, 637 (1979). The dismissal rate in such cases is very high. 1d. at 617-18.

133. See Mnookin \& Kornhauser, Bargaining in the Shadow of the Law: The Case of Divorce, 88 Yale L.J. 950 (1979) (discussing role of legal rules in negotiation of settlements in divorce cases). Priest and Klein conclude that changes in the legal standard affect settlements, not outcomes, by shifting the bargaining advantage. Priest \& Klein, The Selection of Disputes for Litigation, $13 \mathrm{~J}$. Legal Stud. 1, 12-30 (1984). For a debate on the accuracy of their method, sce Priest, Reexamining the Selection Hypothesis: Learning from Wittman's Mistakes, 14 J. Legal Stud. 215 (1985); Wittman, Is the Selection of Cases for Trial Biased?, $14 \mathrm{~J}$. Legal Stud. 185 (1985); see also Galanter, supra note 46, at 32-33 (legal decisions radiate and affect settlement value of cases). But cf. Menkel-Meadow, Toward Another View of Legal Negotiation: The Structure of Problem Solving, 31 UCLA L. Rev. 754, 790-91 (1984) (definitive rulings deter innovative settlement packages).

134. See Simon, The Ideology of Advocacy: Procedural Justice and Professional Ethics, 1978 Wis. L. Rev. 29, 46-47:

[P]rocedure is not being used merely as a more efficient way of enforcing a substantive claim, but also as an instrument of private policy for the vindication 
liberal ethos. The financial burden of litigation is obviously an important factor, ${ }^{135}$ but it is not the only one. The pendency of a lawsuit imposes other costs that settlement can avert, whether or not the claim is well founded. In derivative suits, for example, the defendants' desire to avoid publicity ${ }^{136}$ and to reduce the time drain of litigation ${ }^{137}$ may incline them toward settlement. In antitrust cases, the unavailability of contribution may make the risk of litigation so great that settlement seems essential. ${ }^{138}$ Moreover, the value of a decision by a court deserves some deference; without a body of such decisions the law may not cast a discernible shadow for those who seek to rely on the law in fashioning settlements. ${ }^{139}$ Accordingly, pleadings decisions on the merits seem justified when they can be made reliably.

The pressure to encourage pleadings decisions is far from overwhelming, however, and there is much dispute about the extent to which nuisance settlements are in fact extracted. For example, although the class action procedure has been blamed for breeding vexatious litigation, existing empirical data do not show that the problem is severe. ${ }^{140}$ Litigation cost, the most-cited villain, has an ambivalent

of expectations which are not justified by the substantive law. . . In the vast majority of cases which are settled, there is not even a pretense that the result has been determined by the application of a system of substantive rules to given factual premises.

See also Eisenberg, The Principles of Consideration, 67 Coruell L. Rev. 640, 645 (1982) (labelling "trading on the transaction costs of litigation" as "moral extortion").

135. Thus, Judge Tone explains that "candidates for settlement" can easily be recognized: "They are the cases in which the amount involved is small in relation to the anticipated costs of litigation, or in which relief other than the payment of money is the plaintiff's principal objective and it is less painful for the defendant to give that relief than to bear the expense of further litigation." Tone, supra note 129 , at 62 . The distingnishing feature in these cases, it should be noted, is litigation cost, not strength or weakness on the merits.

136. See Jones, An Empirical Examination of the Resolution of Shareholder Derivative and Class Action Lawsuits, 60 B.U.L. Rev. 542, 546 (1980). The existence of such noneconomic stakes in litigation may, on the other hand, incline defendant against settlement. See Coffee, Understanding the Plaintiff's Attorney: The Implications of Economic Theory for Private Enforcement of Law Through Class and Derivative Actions, 86 Colum. L. Rev. (forthcoming May 1986).

137. See Coffee, The Unfaithful Champion: The Plaintiff as Monitor in Shareholder Litigation, 48 Law \& Contemp. Probs., Summer 1985, at 5, 15.

138. It is true that the absence of contribution reflects in part an assessment of Congress' substantive objectives in enacting the antitrust laws. See Texas Indus. v. Radcliff Materials, Inc., 451 U.S. 630, 639, 645-46 (1981) (court has no authority to provide for contribution in antitrust cases because Congress made contrary legislative judgment). But that judgment was hardly intended to leave one alleged conspirator facing a bankrupting liability to a plaintiff class after all the others have settled, a litigation reality that tends to deprive the defendant of any meaningful opportunity to defend. This reality explains the willingness of defendants to contract with one another for contribution, thereby reducing this settlement leverage. Sec Note, Sharing Agreements Among Defendants in Antitrust Cases, 52 Geo. Wash. L. Rev. 289 (1984).

139. See supra note 133 (discussing effect of legal rules on scttlements).

140. See DuVal, The Class Action as an Antitrust Enforcement Devicc: The 
effect. When the cost of litigating a meritorious claim is greater than the expected recovery, a suit filed in hopes of an early settlement may be characterized as a nuisance suit even though the claim has merit. ${ }^{141}$ Moreover, defendants can limit their costs. ${ }^{142}$ Accordingly, there is no compelling impetus toward radical change, and care is in order before concluding that a particular case can be reliably decided on the pleadings. ${ }^{143}$

Chicago Experience (pt. 2), 1976 Am. B. Found. Research J. 1273, 1344-46 (little indication that class allegations affect settlement value); Note, The Rule 23(b)(3) Class Action: An Empirical Study, 62 Geo. L.J. 1123, 1137 (1974) (even defense counsel label only a handful of class actions frivolous). But cf. Kennedy, Securities Class and Derivative Actions in the United States District Court for the Northern District of Texas: An Empirical Study, 14 Hous. L. Rev. 769, 824-26 (1977) (class allegations give plaintiff settlement leverage). Thus, concern about abuse of the class action device has abated. See Miller, Of Frankenstein Monsters and Shining Knights: Myth, Reality, and the "Class Action Problem," 92 Harv. L. Rev. 664 (1979).

141. See Rosenberg, The Causal Connection in Mass Exposure Cases: A "Public Law" Vision of the Tort System, 97 Harv. L. Rev. 849, 896 n.I71 (1984); Rosenberg \& Shavell, A Model in Which Suits Are Brought for Their Nuisance Value, 5 lnt'l Rev. L. \& Econ. 3 (1985).

142. Thus Robert Banks, General Counsel of Xerox Corp., reports that "corporate lawyers are working to decrease costs by focusing in on the net value of every motion, every pleading, every discovery." Annual Judicial Conference Second Judicial Circuit of the United States, 101 F.R.D. 161, 191 (1983); see also Smith, "Top-Dollar Clients" Can Limit Expenses, Legal Times, June 11, 1984, at 22, col. 2 (providing suggestions on how clients can economize on legal services).

143. One suggested antidote to the cost problem is cost shifting. Because the principal component of litigation expense is attorneys' fees, some urge that we adopt the English system of routinely awarding the winner his attorneys' fees. Under such a regime, one might argue that litigants should be allowed to make their litigation investment decisions without interference from possibly premature efforts to decide cases on motions to dismiss, and that such decisions should therefore be discouraged. For several reasons, increased cost shifting is not an alternative to early merits decisions.

First, reliance on economic decisions of litigants unduly devalues judicial decisionmaking as a device for clarifying rules of law. Without adopting Professor Fiss' view, sec supra note 128 and accompanying text, it remains true that litigants seeking to settle cases in the "shadow of the law" need judicial assistance in discerning the contours of that shadow. See supra text accompanying notes 133,139 . The small number of cases that are tried would not be sufficient for this purpose.

Second, despite the existence of a body of judicial decisions the law is often uncertain, and litigants must guess as best they can about the outcome of their suit. Denying them a prompt decision where it can reliably be made simply increases for no good reason the amount that will ultimately be imposed on the loser. In this connection, it is unclear whether adopting routine attorneys' fee awards would increase expenditures on litigation by increasing the stakes. See Braeutigam, Owen \& Panzar, An Economic Analysis of Alternative Fee Shifting Systems, 47 Law \& Contemp. Probs., Winter 1984, at $173,180-81$.

Third, awarding attorneys' fees does not, in many cases, fully compensate the winning party for noneconomic costs resulting from the suit. See supra notes 135-137 and accompanying text. Deferring decision would continue for no good reason to impose these uncompensated costs on a party who ultimately wins.

Fourth, the availability of attorneys' fees awards may stimulate the filing of some kinds of suits, thus increasing the need to scrutinize the grounds for such suits. Sec 


\section{B. Legal Conclusions: Implementing the Substantive Law}

Both sides of the settlement-dispute resolution controversy wish ultimately to implement the substantive law. That is, after all, the generally accepted objective of procedure. ${ }^{\mathbf{1 4 4}}$ But the substantive law may frustrate that goal in the pleading context by relying on rules that can only be applied with reference to a multitude of factors or factual matters that cannot be adequately assessed at the pleading stage. Whether or not it is inevitable that legal rules will become more uncertain over time, ${ }^{145}$ it is certainly true that the evolution of the law away from precise (and rather arbitrary) rules has reduced the utility of pleading decisions. ${ }^{146}$

A simple example illustrates this difficulty. Before 1938, the detail required to plead negligence was the subject of much dispute, a past the Federal Rules sought to bury with Form $9 .{ }^{147}$ But the underlying problem with pleading decisions was not really procedural. It was substantive because the negligence determination turned on such a variety of circumstances that it could not reliably be made on the basis of

Pulliam v. Allen, 466 U.S. 522, 555-56 (1984) (Powell, J., dissenting) (asserting that since enactment of Civil Rights Attorney's Fees Awards Act, 42 U.S.C § 1988 (1982), civil rights suits have "increased geometrically").

In sum, while fee shifting as a sanction may hold some promise, see supra note 66 and accompanying text, the prospect of greater private policing of the decision to file suit through economic incentives caused by fee shifting provides no reason for abandoning interest in refining the pretrial motion process.

144. The adoption of the Federal Rules was not intended to alter the outcome except to assure that it corresponds to the merits under what is understood to be the substantive law. Indeed, the Rules Enabling Act, 28 U.S.C. $\$ 2072$ (1982), precludes such tampering with substantive law. This Article proceeds on that understanding.

145. See D'Amato, Legal Uncertainty, 71 Calif. L. Rev. I, 1 (I983) ('Legal certainty decreases over time. Rules and principles of law become more and more uncertain in content and in application because legal systems are biased in favor of unravelling those rules and principles."); Epstein, Settlement and Litigation: Of Vices Individual and Institutional, 30 U. Chi. L. Sch. Rec. 2, 5-7 (1984) (complexity and uncertainty of modern substantive rules contribute to increase in frequency and severity of litigation). In part, the development can be seen as a shift from hard-and-fast "rules" to more flexible "standards." See Kennedy, Form and Substance in Private Law Adjudication, 89 Harv. L. Rev. 1685 (1976).

146. See Clark, supra note 71 , at 51 (The real problem with pleadings decisions in antitrust cases is that the Sherman Act is broad.); Epstein, Pleadings and Presumptions, 40 U. Chi. L. Rev. 556, 566 (1973) (referring to "the importance [in evaluating pleadings] of an exact knowledge of the substantive theory in question in order to distinguish ultimate issues of fact from the questions of proof that they raise"); Kingdon, supra note 75 , at 34 (lack of clear standards in antitrust field is one cause of vague pleading); $c f$. Miller, supra note 140, at 672-73 (watering down substantive rnles increases litigation). The same phenomenon can be seen at the summary judgment stage. See, e.g., Tunis Bros. v. Ford Motor Co., 763 F.2d 1482, 1502 (3d Cir. 1985) ("Under the 'rule of reason' standard, there is a greater reluctance to uphold a grant of summary judgment where the conduct is to be examined for its reasonableness than where it is to be subjected to a per se rule.").

147. See supra notes 31,36 and accompanying text. 
pleadings, whatever detail they contained. Had negligence law been atomized into a multitude of concrete subrules, the resulting emphasis on specific points could have permitted pleading decisions in many cases. It may be argued that the law has gone too far toward multifactor generality, ${ }^{148}$ but that problem is substantive, not procedural.

Nonetheless, the substantive law can provide tools that permit pleadings dispositions. The courts' handling of such cases falls generally into two categories: Cases in which the substantive law requires a certain element that is missing and cases in which the court, by carefully analyzing the totality of the plaintiff's allegations, can sensibly decide on the basis of the pleadings that the defendant did not violate the law.

1. Using Pleadings to Identify Missing Elements. - Although it may begin as an amorphous proscription, the substantive law can sharpen over time so that specific elements of a claim can be identified and applied at the pleading stage. For example, when the Supreme Court held in Blue Chip Stamps that securities fraud plaintiffs had to be purchasers or sellers, ${ }^{149}$ the lower courts had a new substantive tool to use in evaluating complaints. ${ }^{150}$ Similarly, when the Court held that only direct purchasers could sue for price fixing, ${ }^{151}$ the lower courts could entertain motions to dismiss suits by indirect purchasers. ${ }^{152}$ Just this last Term, the Court confirmed that misrepresentation or nondisclosure is a necessary element for a claim under the Williams Act, ${ }^{153}$ and the same process may be expected there.

The process works more actively in emerging areas of law. Consider, for example, the burgeoning civil litigation under the 1970 Racketeer Influenced and Corrupt Organizations Act (RICO), 154 which epitomizes the litigation boom. The statute, as one court put it, is "constructed on the model of a treasure hunt."155 In a provision little discussed in Congress, it authorizes a private action for treble damages, plus an award of attorneys' fees, for "[a]ny person injured in his business or property by reason of a violation." 156 The key triggering event for a violation is a "pattern of racketeering activity." 157 The statute forbids use of income from such an activity in operation of a business

148. For an argument that specificity in pleading could be useful in negligence cases, in conjunction with modifications in the substantive law, sce Epstcin, supra note 146, at 566 .

149. See supra notes 58-60 and accompanying text.

150. See, e.g., Sacks v. Reynolds Sec., Inc., 593 F.2d 1234, I239-41 (D.C. Cir. 1978) (dismissal pursuant to Blue Chip Stamps).

151. See Illinois Brick Co. v. Illinois, 431 U.S. 720 (1977).

152. See, e.g., Merican, Inc. v. Caterpillar Tractor Co., 713 F.2d 958, 965-69 (3d

Cir. 1983) (dismissal pursuant to Illinois Brick), cert. denied, 465 U.S. 1024 (1984).

153. Schreiber v. Burlington N., Inc., 105 S. Ct. 2458 (1985).

154. 18 U.S.C. §§ 1961-1968 (1982).

155. Sutliff, Inc. v. Donovan Cos., 727 F.2d 648, 652 (7th Cir. 1984).

156. 18 U.S.C. $\$ 1964$ (c) (1982).

157. Id. \& 1962. 
engaged in interstate commerce, ${ }^{158}$ acquiring a business through such activity, ${ }^{159}$ or participation in the conduct of the affairs of an enterprise through such activity. ${ }^{160}$ A "pattern of racketeering activity," in turn, requires the commission within ten years of two or more "predicate acts," which include violation of one of a series of criminal statutes. ${ }^{161}$ Since mail fraud ${ }^{162}$ and wire fraud ${ }^{163}$ are included in this list, "garden variety fraud" could be catapulted into a treble damage action with the addition of the lurid term "racketeering" to the complaint.

For about ten years after RICO was passed, the civil suit provisions languished. Around 1980, however, a wave of litigation under the statute began. This has caused an uproar in the courts. ${ }^{164}$ Some courts have tried to graft requirements onto the statute and dismiss cases that do not satisfy those requirements. Most notably, the Second Circuit decided that a RICO claim could not lie unless the defendant had been convicted of the predicate acts. ${ }^{165}$ Courts also dismissed cases for failure to allege links to organized crime, ${ }^{166}$ a special RICO injury, ${ }^{167}$ or an enterprise separate from the person accused of violating the Act. ${ }^{168}$ The Supreme Court has recently rejected certain of these elements, ${ }^{169}$

158. Id.

159. Id. § 1962(b).

160. Id. § I $962(\mathrm{c})$.

161. Id. $\S 1961(1)$. The pattern requirement has been interpreted to mandate something more than the predicate acts. See Northern Trust Bank/O'Hare, N.A. v. Inryco, Inc., 615 F. Supp. 828 (N.D. Ill. 1985) (predicate acts must show both continuity and relationship to each other).

162. 18 U.S.C. $\$ 1341$ (1982).

I63. Id. $\$ 1343$.

164. "Congress ... may well have created a runaway treble damage bonanza for the already excessively litigious." Schacht v. Brown, 711 F.2d 1343, I361 (7th Cir.), cert. denied, 464 U.S. 1002 (1983); see Pickholz, The Firestorm Over Civil RICO, A.B.A. J., Mar. 1985, at 78. Antitrust plaintiffs with weak claims (but not those with strong ones) are advised to add RICO claims. See Fricano \& Brusca, RICO Route May Suit Potential Antitrust Plaintiffs, Legal Times, Apr. 8, 1985, at 17, col. 1.

165. Sedima, S.P.R.L. v. Imrex Co., 741 F.2d 482 (2d Cir. 1984), rev'd, 105 S. Ct. 3275 (1985).

166. See Barr v. WU1/TAS, Inc., 66 F.R.D. 109 (S.D.N.Y. 1975). But see Schacht v. Brown, 711 F.2d 1343 (7th Cir.), cert. denied, 464 U.S. 1002 (1983); see also Note, Civil RICO: The Temptation and Impropriety of Judicial Restriction, 95 Harv. L. Rev. 1101 , 1106-09 (1982) (disapproving requirement of organized crime link).

167. See Bankers Trust Co. v. Rhoades, 741 F.2d 511 (2d Cir. 1984), vacated, 105 S. Ct. 3550 (1985).

168. See United States v. Computer Sciences Corp., 689 F.2d 1181, 1190-91 (4th Cir. 1982), cert. denied, 459 U.S. 1105 (1983). But see United States v. Hartley, 678 F.2d 961, 987-90 (1 lth Cir. 1982), cert. denied, 459 U.S. 1170 (1983); see also Haroco, lnc. v. American Nat'l Bank \& Trust Co., 747 F.2d 384, 401 (7th Cir. 1984) ("Discussion of this person/enterprise problem under RICO can casily slip into a metaplyysical or ontological style of discoursc-after all, when is the person truly an entity 'distinct' or 'scparate' from the enterprise?"), aff'd on other grounds, $105 \mathrm{~S}$. Ct. 3291 (1985).

169. Sec Scdima, S.P.R.L. v. Imrcx Co., 105 S. Ct. 3275 (1985) (rcjecting requircment of conviction for predicate acts); Amcrican Nat'l Bank \& 'Trust Co. v. Haroco, lnc., l05 S. Ct. 3291 (1985) (civil claim under RICO necd not allege damages suffered 
so that some opportunities for dismissal have disappeared, although others may arise. ${ }^{170}$

The experience under RICO illustrates how limits imposed by the substantive law can frustrate efforts to facilitate dismissal of cases. Despite the intensity of the lower courts' attempts to locate grounds for dismissal, the Supreme Court has suggested that the RICO boom can only be curtailed by amending the statute. ${ }^{171}$ Similar substantive constraints may hamper efforts to develop grounds for dismissal in other areas as well. Whatever the pressures of the litigation boom, then, often the substantive law simply will not support development of the kind of separable issues that can be used to winnow cases at the pleading stages.

Where the substantive law does provide such separable issues, it will often be necessary, in response to the natural urge towards vagueness in pleading under the Federal Rules, ${ }^{172}$ for a court to demand additional particulars to resolve such separable issues. This emphasis on detail differs significantly from the notice pleading idea because it seeks to elicit details that will allow resolution of the case at the outset. ${ }^{179}$ But the existence of such a severable issue does not mean that making an early decision will always be easy. Consider, for example, pleadings dispositions on statute of limitations grounds. Although it is an affirmative defense, limitations can be raised by motion to dismiss, and the plaintiff can be required to provide details sufficient to evaluate the limitations question. Despite the seemingly automatic application of limitations, however, the law has over time developed equitable doctrines regnlating accrual and tolling that turn on the facts of the particular case and therefore often preclude pretrial decision. ${ }^{174}$ Even where a severable issue can be identified, a reliable merits decision at the outset may be impossible.

2. Pleadings Determinations that Defendant Has Not Violated the Plaintiff's Rights. - Even without segregating a separable issue a court may, with sufficient details, be able to decide at the pleading stage that the de-

through violation of predicate offenses). While acknowledging that plaintiffs must allege each element of a RICO claim, the Court, by a 5-4 vote, held that the Second Circuit's efforts to construct new elements for a claim were invalid. Sedima, $105 \mathrm{~S}$. Ct. at 3286. The majority recognized that the dramatic growth in civil RICO cases may not be what Congress had in mind, but said that if correction is necessary it should come from Congress. Id. at 3287.

170. In Sedima, the Court clearly enunciated four requirements that must be alleged to state a claim: "(1) conduct (2) of an enterprise (3) through a pattern (4) of racketeering activity." $105 \mathrm{~S}$. Ct. at 3285 (footnote omitted). It remains to be seen how the lower courts will apply these elements, particularly the third and fourth, at the pleading stage.

171. See supra note 169 .

I72. See supra notes 74-76 and accompanying text.

173. See supra note 124 and accompanying text (discussing use of motions for a more definite statement to accomplish this purpose).

174. Sec Marcus, Fraudulent Concealment in Federal Court: Toward a Morc Disparate Standard?, 71 Geo. L.J. 829, 902-04 (1983). 
fendant has not violated the plaintiff's rights. For example, in 1976 the Supreme Court upheld dismissal of a prisoner suit alleging that defendants' denial of medical care constituted cruel and unusual punishment. ${ }^{175}$ Although it reaffirmed the policy that pro se complaints should be liberally construed, ${ }^{176}$ the Court rejected this prisoner's claim because his "complaint provide[d] a detailed factual accounting of the treatment he received. . . . It is apparent from his complaint that he received extensive medical care and that the doctors were not indifferent to his needs." 177

Such case-specific decisions are possible in a number of contexts, and the courts' rejection of conclusory allegations often reflects the sensible belief that more detail may reveal a basis for dismissal. Civil rights cases provide a good example; it is commonplace now for courts to hold that conclusory allegations are insufficient to state a claim. ${ }^{178}$ This is no mere formality. The tendency of litigants to repackage anything that strikes them as unfair as a violation of due process compels the courts to demand more information about the historical events that the plaintiff claims occurred. Often these details demonstrate that the incident constituted at most a state law tort, and dismissal follows. ${ }^{179}$

Merits determinations of this type are not limited to civil rights cases. The willingness of many courts to find that the facts as pleaded reveal no legal violation reflects an approach to dispositions on the merits at the pleading stage that Conley $v$. Gibson would not appear to permit. In Car Carriers, Inc. v. Ford Motor Co. ${ }^{180}$ for example, the Seventh Circuit expressly rejected a literal application of the Conley stan-

175. Estelle v. Gamble, 429 U.S. 97 (1976).

176. Id. at 106 (citing Haines v. Kerner, 404 U.S. 519 (1972)).

177. Id. at 108 n.16. For a similar dismissal of a prisoner case, see Benson v. Cady, 761 F.2d 335 (7th Cir. 1985).

178. See, e.g., Williams v. Gorton, 529 F.2d 668, 671 (9th Cir. 1976) (Conclusory allegations, unsupported by facts, are insufficient to state a claim under the Civil Rights Act.).

179. See, e.g., Rodgers v. Lincoln Towing Serv., 771 F.2d 194 (7th Cir. 1985) (delay in booking suspect due to negligence not a valid civil rights claim); Wright v. Anthony, 733 F.2d 575, 577 (8th Cir. 1984) (no constitutional violation where plaintiff was allowed to submit only written statement to congressional committee rather than full oral statement); Woodard v. Los Fresnos Indep. School Dist., 732 F.2d 1243 (5th Cir. 1984) (departure from school rnles regarding punishment at most a tort, not a violation of constitutional rights); Green v. Maraio, 722 F.2d 1013 (2d Cir. 1983) (prisoner's action against state court judge dismissed because judge did not act with clear absence of jurisdiction and was therefore immune).

These cases should be distinguished from other civil rights actions dismissed by the courts for lack of state action, e.g., Cohen v. lllinois Inst. of Technology, 58 I F.2d 658 (7th Cir. 1978) (conclusory allegation that state and federal support to private school constituted support for specific discriminatory practices insufficient), cert. denied, 439 U.S. 1135 (1979), which fits the mold discussed supra notes 149-74 and accompanying text, of severable elements for which specifics may be demanded.

180. 745 F.2d 1101 (7th Cir. 1984), cert. denied, 105 S. Ct. I758 (1985). 
dard in upholding the dismissal of an antitrust complaint. ${ }^{181}$ Plaintiffs had provided car transportation services to Ford Motor Company for a number of years until Ford terminated the arrangement and contracted with another company for those services. Plaintiffs sued Ford and the new transport company, alleging that defendants had entered into a conspiracy to drive plaintiffs out of business, switched the contract to provide transport services through a "sham and knowingly predatory bid," and thereby enabled the competitor to acquire plaintiffs' assets for less than their true value. ${ }^{182}$ The trial court granted defendants' motion to dismiss. ${ }^{183}$

The Seventh Circuit affirmed, reasoning that "Conley has never been interpreted literally" 184 and that, in practice, "a complaint . . . must contain either direct or inferential allegations respecting all the material elements necessary to sustain a recovery under some viable legal theory." "185 Measured against this standard, the court found the specific factual allegations to contradict, rather than support, any viable theory for plaintiffs. To prevail, plaintiffs had to allege either a per se violation of the antitrust laws or a forbidden effect on competition. Although plaintiffs used the per se label, ${ }^{186}$ they had not alleged that defendants had terminated plaintiffs' services as retaliation for price cutting, which is traditionally handled as a per se violation. To the contrary, plaintiffs alleged that they had continually sought to raise their prices. ${ }^{187}$ Further, even if their allegations of a conspiracy were credited as showing a group boycott, that would constitute a per se violation only if used to implement agreements that themselves constituted per se violations, which the complaint failed to show. ${ }^{188}$ The ominous reference to "sham" and "predatory" behavior, the court concluded, stated no more than a legal conclusion: "it would be improper for us to attempt to conjure up some sort of tenable antitrust scheme for these cryptic allusions." 189 Plaintiffs' effort to allege an anticompetitive impact similarly failed: "In considering a motion to dismiss, the court is not required to don blinders and to ignore commercial reality."190 Hence, plaintiffs' assertions about "predatory" actions meant nothing, the court found, because it would be "preposterous" for Ford

181. 1d. at 1106.

182. Id. at 1105 .

183. 561 F. Supp. 885,889 (N.D. 1ll. 1983).

184. 745 F.2d at 1106 (citation omitted).

185. 1d. (quoting in re Plywood Antitrust Litig., 655 F.2d 627, 641 (5th Cir. 1981)).

186. ld. at 1108.

187. $1 \mathrm{~d}$.

188. 1d. at 1109 .

189. Id. at 1109 n.5; see also id. at 1107 n.4 ("Standing alone, the boilerplate recitation of a conspiracy in . . the complaint is insufficient to withstand a motion to dismiss.").

190. Id. at 1110 . 
to arrange to be the victim of such activity. ${ }^{191}$ To uphold this complaint, the court concluded, would undercut the Sherman Act by undermining a buyer's right to replace its supplier. ${ }^{192}$

Car Carriers strains the outer limits of pleading practice. Although courts can sometimes make such determinations on the basis of detailed pleadings, ${ }^{193}$ it will not often be possible to do so. Certainly, insistence on detailed pleading should not be used to obscure unsettled issues of substantive law, ${ }^{194}$ and using pleadings as an opportunity to evaluate the whole of the plaintiff's allegations may tempt courts to question the factual conclusions on which the plaintiff has rested his claim, ${ }^{195}$ a temptation that courts should resist.

191. Id. The court at two points discounted plaintiffs' allegations as "inherently implausible." See id. at 1107 n.4, 1109 . Although this language suggests that it was evaluating the persuasiveness of plaintiffs' evidence, a highly questionable course, see infra notes 196-227 and accompanying text, it should be considered as part of its reference to commercial reality. See supra text accompanying note 190 .

192. $745 \mathrm{~F} .2 \mathrm{~d}$ at 1110 .

193. See, e.g., Sante Fe Indus. v. Green, 430 U.S. 462, 474 (1977) (affirming dismissal of securities claim because "the transaction, if carried out as alleged in the complaint, was neither deceptive nor manipulative").

194. This seems to be the objection of Professor Roberts in his article on the application of fact pleading to standing cases. See Roberts, supra note 12, at 421-25. But the root problem there is substantive; as Professor Chayes has observed, the Supreme Court has a ritual recitation of the "rules" goveruing standing and, " $[t]$ his ritual recitation having been performed, the Court then chooses up sides and decides the case." Chayes, The Supreme Court 1981 Term-Foreword: Public Law Litigation and the Burger Court, 96 Harv. L. Rev. 4, 23 (1982). As Professor Roberts argues, the Court may be using pleading language to hide its failure to reach consensus on the law of standing. See Roberts, supra note 12, at 421 . Were there such a consensus, however, it might be that standing questions could often be resolved on the pleadings with sufficient particulars, although Professor Roberts remains dubious owing to the ambiguity of substantive standing doctrine. See id. at 430 . If so, standing is like many other substantive legal rules that can only be applied with reference to a multitude of factors and are therefore not readily subject to application at the pleading stage. See supra notes 145-48 and accompanying text. But cf. Page, The Scope of Liability for Antitrust Violations, 37 Stan. L. Rev. 1445, 1448 (1985) (arguing that antitrust standing rules are well suited to summary disposition).

195. One way they might do this is by mischaracterizing essentially factual conclusions as legal conclusions. For example, in Strauss v. City of Chicago, 760 F.2d 765 (7th Cir. 1985), the plaintiff alleged an unprovoked beating by a police officer for which he claimed the city was liable due to its practice of hiring and retaining brutal police officers. In support of his allegation that the city had such a practice, he submitted statistical summaries of complaints filed about police behavior. Although it claimed to follow Conley, id. at 767-68, the Seventh Circuit affirmed dismissal because it found the statistical material too general, id. at $768 \& \mathrm{n} .4$, a circumstance it held "renders the allegations mere legal conclusions of Section 1983 liability devoid of any well-pleaded facts," id. at 767. Compare Payne v. City of LaSalle, I Fed. R. Serv. 3d (Callaghan) 11 16, 1117 (N.D. III. 1985) (suggesting Strauss creates a Catch-22 situation for the $\S 1983$ plaintiff suing a municipality). 


\section{The Problem of Factual Conclusions Contrasted}

The thrust of many of the new fact pleading cases is to challenge the plaintiff's "conclusory" factual allegations, often about the defendant's state of mind. Car Carriers could be criticized as doing so, but it focuses on the legality of defendants' conduct as alleged rather than plaintiffs' inability to marshall enough evidence to support their factual conclusions.

The line between scrutiny of legal conclusions and scrutiny of factual conclusions is often obscure, however. For example, in Decker $v$. Massey-Ferguson, Ltd., ${ }^{196}$ plaintiff sued on behalf of a class of purchasers of Massey-Ferguson stock, charging that the company, a producer of farm machinery, had committed securities fraud by painting too rosy a picture of itself in its 1975 annual report and other documents. After ordering plaintiff to amend his complaint to identify the specific statements claimed to be false, the district court dismissed. ${ }^{197}$

Citing the Supreme Court's warnings about strike suits in Blue Chip Stamps, ${ }^{198}$ the Second Circuit affirmed. It did so by comparing the allegations in plaintiff's "prolix and discursive 69 page complaint"1 199 with the 1975 annual report and other documents issued by Massey. On the basis of this comparison, it found plaintiff's allegation that Massey had falsely claimed record profits "patently false" because the reports were "replete with facts and figures whose accuracy has not been challenged" that showed just such profits. ${ }^{200}$ Similarly, it rejected plaintiff's claim that Massey should have announced that it was undercapitalized because its capitalization and debt structure were fully disclosed in its financial reports. ${ }^{201}$ it also held that Massey's 10-K filings with the SEC "substantially satisfied" then-applicable regulations, and that any forecasts contained in the report were not actionable. ${ }^{202}$

Decker seems to further the objectives of the substantive law because it reflects the court's conviction that defendants had not violated the law. Hence, Decker might be viewed, at least in part, as a legal conclusion case. In particular, the court's conclusions that Massey's 10-K filings satisfied applicable regulations and that forecasts are not actionable appear to mandate dismissal. But the handling of other claims is troubling. Undoubtedly, "patently false" charges should not enable a plaintiff to use broad discovery to bludgeon a nuisance settlement out of defendants. But where the focus is on factual conclusions, one loses

196. 681 F.2d 111 (2d Cir. 1982).

197. Decker v. Massey-Ferguson, Ltd., 534 F. Supp. 873, 884 (S.D.N.Y. 1981), aff'd, 681 F.2d 111 (1982).

198. Blue Chip Stamps v. Manor Drug Stores, 421 U.S. 723, 740 (1975); sce supra notes 58-60 and accompanying text.

199. 681 F.2d at 114 .

200. Id. at 115 .

201. 1d. at 116 .

202. 1d. at 116-17. 
the confidence, present in a legal conclusion case, that a decision to dismiss on the merits is sufficiently reliable.

Decker illustrates the point even though plaintiff's claim there seems to have been extremely weak. Although the court was able to cite "facts and figures whose accuracy has not been challenged," there is at least a nagging doubt about whether plaintiff could have challenged those figures had he been allowed discovery. ${ }^{203}$ Moreover, the appellate court seemed to be relying on material that was not contained in the complaint, ${ }^{204}$ which would normally convert the motion to dismiss into a motion for summary judgment. ${ }^{205}$ lndeed, evaluation of certain securities law claims may inherently be unworkable on the pleadings. ${ }^{206}$ ln Decker, the court might well have concluded that plaintiffs should be afforded little or no discovery before ruling on summary judgment, ${ }^{207}$ but handling the motion in the summary judgment format better accords with the objective of assuring that the outcome accurately reflects the substantive merits.

The difficulties with scrutinizing factual conclusions become manifest in connection with the frequent demand that the plaintiff proffer sufficient supporting evidence to make conclusory allegations, particu-

203. See Note, supra note 12 , at 1437 (criticizing Decker for denying plaintiff discovery of internal memoranda and projections).

204. For example, the court cited a New York Times story about John Deere \& Co., another manufacturer of agricultural implements, to support its conclusion that the period after 1975 was "the type of economic climate in which section 10(b) litigation flourishes." $681 \mathrm{~F} .2 \mathrm{~d}$ at 114. The court stated that Massey's 1975 annual report was "in the record," but it did not say that the document was an exhibit to plaintiff's complaint, although its citation to pertinent authority under Fed. R. Civ. P. 10(c) suggests it may have been. See 681 F.2d at 113 (citing 5 C. Wright \& A. Miller, supra note 3, § 1327, at 491 n.18). In any event, the court appeared to look beyond the 1975 annual report and referred to Massey's consolidated financial statements, SEC filings, and 1977 annual report. See id. at 117.

205. See Fed. R. Civ. P. 12(b).

206. The Decker court's approach seems quite different from the attitude in Goldman v. Belden, 754 F.2d 1059 (2d Cir. 1985), in which the court reversed dismissal of a securities class action, stating:

The court's view that the facts may not really have been problems was not so much a ruling as to the adequacy of the pleading as it was an evaluation of the materiality of the nondisclosures. Materiality is a mixed question of law and fact, and a complaint may not properly be dismissed pursuant to Rule 12(b)(6) (or even pursuant to Rule 56) on the ground that the alleged misstatements or omissions are not material unless they are so obviously unimportant to a reasonable investor that reasonable minds could not differ on the question of their importance.

Id. at 1067 (citation omitted); see also Eichler v. Berner, 105 S. Ct. 2622, 2629 n.21 (1985) ("We note . . . the inappropriateness of resolving the question of the respondents' fault solely on the basis of the allegations set forth in the complaint."). Although there may be a distinction between determining whether a statement is "false" and whether it is "material," any such distinction seems insufficient to support such a difference in treatment.

207. See infra notes $317-29$ and accompanying text. 
larly those relating to state of mind, 208 credible. In these cases, unlike Decker, the court is not affirmatively concluding that plaintiff's charges are false, but only that they are unsupported. Although the desire to insist on some underlying evidence is natural, that exercise is materially different from the substantive scrutiny described above. Requiring plaintiff to proffer supporting evidence at the pleadings stage cannot be justified for several reasons.

First, this attack on factual conclusions stands the code distinction between ultimate facts and evidence on its head. State of mind is undoubtedly a fact, even now sometimes labelled an "ultimate fact."200 The insistence on more details is really a demand for an offer of proof-some specification of evidence that will raise an inference that the defendant's state of mind was as alleged. This creation of a new burden of production effects a subtle but real shift in the substantive law because plaintiff's lack of evidence provides insufficient assurance that plaintiff in fact has no valid claim against defendant. ${ }^{210}$

Where the court requires detailed support for a legal conclusion, analysis of the details may permit the court to conclude confidently that the plaintiff has no case. ${ }^{211}$ But where the plaintiff is unable to provide details because only the defendant possesses such information, no such confidence is possible. ${ }^{212}$ To the contrary, it may be that the defendant has so effectively concealed his wrongdoing that the plaintiff can unearth it only with discovery. To insist on details as a prerequisite to discovery is putting the cart before the horse. RICO provides an illustration. Rather than requiring that the defendant be convicted of the offenses that the plaintiff relied upon as predicate acts, ${ }^{213}$ some courts insisted that, where defendant had not been convicted, plaintiff plead sufficient facts to provide probable cause to believe that defendant was guilty of the predicate offenses.214 The Seventh Circuit, however, properly refused to impose this pleading requirement because plaintiffs have no opportunity for discovery before filing suit. ${ }^{215}$

208. See supra notes $90-93,96$ and accompanying text.

209. See Herbert v. Lando, 441 U.S. 153, 170 (1979) (defendant's actual malice an "ultimate fact" in defamation cases); see also Bose Corp. v. Consumers Union of United States, Inc., 466 U.S. 485, 498 (1984) (knowledge a "fact").

210. Cf. Hazard, The Effect of the Class Action Device Upon the Substantive Law, 58 F.R.D. 307,307 (1973) ("[I]t seems fair to say that procedure's very function is to modify the substantive law."). But see supra note 144 .

211. See supra notes $175-95$ and accompanying text.

212. See Note, supra note 12 , at 1435 ("[T] he inflexible application of the particularity requirement in contemporary securities fraud cases inevitably results in the dismissal of some meritorious claims.").

213. See supra note 165 and accompanying text.

2I4. See Taylor v. Bear Stearns \& Co., 572 F. Supp. 667, 682-83 (N.D. Ga. 1983); Bache Halsey Stuart Shields Inc. v. Tracy Collins Bank \& Trust Co., 558 F. Supp. 1042, 1045-46 (D. Utah 1983).

215. See Haroco, Inc. v. American Nat'l Bank \& Trust Co., 747 F.2d 384, 404 (7th Cir. 1984), aff'd on other grounds, 105 S. Ct. 3291 (1985). 
Second, insistence on detailed evidence regarding state of mind violates the second sentence of Rule 9(b), which specifies that "[m]alice, intent, knowledge, and other condition of mind of a person may be averred generally." 216 On its face, this sentence precludes use of the Rule to require plaintiffs to provide particulars on the very matters for which so many courts say that supporting facts are now required. ${ }^{217}$

Third, the new scrutiny of the proof regarding factual conclusions calls for judgments for which the legal system presently lacks an appropriate standard. How much evidence is enough? Consider Ross v. A.H. Robins $C_{0},{ }^{218}$ where the Second Circuit held that plaintiff in a securities fraud action had failed to allege sufficient facts to support the conclusion that defendants knew by 1973 of the dangers of the Dalkon Shield. ${ }^{219}$ Plaintiffs had provided some detail by pointing out that in 1972 an independent researcher had identified and reported on the risks of the device and that in May, 1974, Robins itself had sent a letter to 120,000 doctors alerting them to possible health problems resulting from use of the device. The appellate court held that this showing was insufficient without some connection between the independent researcher and Robins. ${ }^{220}$

The court's insistence on more evidence is difficult to understand. Even if there were no connection between the researcher and Robins, the fact that the researcher could independently assemble data on the harmful effects of the device by 1972 certainly supports the inference that Robins could readily have done so itself or at least have learned of the independent report. Indeed, other cases have shown that Robins made a practice of gathering data on the safety of the Dalkon Shield. ${ }^{221}$ It had earlier made a number of public statements, presumably based on the investigations of skilled persons, about the safety of the prod-

216. Fed. R. Civ. P. 9(b); see Wayne Inv., lnc. v. Gulf Oil Corp., 739 F.2d 11, 13 (1st Cir. 1984) (Rule 9(b) does not require particulars from which intent can be inferred) (citation omitted).

217. See supra notes $90-93$ and accompanying text.

218. 607 F.2d 545 (2d Cir. 1979), cert. denied, 446 U.S. 946 (1980).

219. See supra notes $91-93$ and accompanying text.

220. See 607 F.2d at 558 .

221. For a detailed review of the efforts actually made by Robins to evaluate the safety of this new product, see the post-trial findings of fact in Hawkinson v. A.H. Robins Co., 595 F. Supp. 1290, 1295-1306 (D. Colo. 1984). The Hawkinson court found further that "Robins could have learned about and warned of such dangers with the application of the reasonable skill and foresight expected of an established pharmaceutical company," and that "Robins not only failed to disclose its lack of knowledge; it affirmatively asserted that the Shield was safe." Id. at 1307. This is not to suggest that the outcome of this personal injury case should affect the decision of a securities fraud suit, given the different culpability showing required in a securities fraud action, but only to show that the need for more detailed allegations to get into discovery in Ross is difficult to square with the results of discovery in other cases. 
uct. ${ }^{222}$ By May, 1974, it was sufficiently alarmed about safety to write over one hundred thousand doctors. The court of appeals felt, however, that any inference of knowledge was not a "strong" inference. ${ }^{22 y}$ Whatever this standard requires, it is not defined anywhere in the Federal Rules.

Fourth, this analysis invites weighing of evidence. It is traditionally said that the likelihood of plaintiff's success on the factual merits is not a proper subject for evaluation at the pleading stage. ${ }^{224}$ Yet the courts do weigh the likelihood that plaintiff will be able to prove its factual conclusions. In a recent civil rights suit, for example, the Ninth Circuit affirmed dismissal because the "factual surroundings" cut against the plaintiff's conclusion of racial motivation. ${ }^{225}$ Such a determination at the pleading stage is highly troubling. The better view was articulated by the Seventh Circuit in refusing to impose a probable cause standard in RICO suits: "Even the most specific allegations do not establish probable cause unless they are reliable. We are, to say the least, perplexed as to how a court might undertake such evaluations of reliability in deciding a motion to dismiss under Rule 12."226 To suggest that courts can do so stands in stark contrast to the standard for grant of summary judgment, where any reasonable inference favoring the party opposing summary judgment is said to create an issue of fact precluding pretrial disposition. ${ }^{227}$

In sum, the courts' tendency to scrutinize the proof supporting

222. See S. Englemayer \& R. Wagman, Lord's Justice 39-54 (1985) (detailing statcments made by Robins, and contrasting them to evidence available to Robins). Indeed, Robins even used information from Mary Gabrielson, upon whose report the plaintiff in Ross relied, see 607 F.2d at 558, in publicity designed to assuage doubts about the safety of the Dalkon Shield. See S. Englemayer \& R. Wagman, supra, at 48-50.

223. Ross, 607 F.2d at 558. Lest it be thought that the judges of the Second Circuit can easily apply this kind of demanding standard, consider Albany Welfare Rights Org. Day Care Center, Inc. v. Schreck, 463 F.2d 620 (2d Cir. 1972), cert. denied, 410 U.S. 944 (1973). Plaintiff claimed that defendant county officials refused to refer children to its child care facilities in retaliation for plaintiff's organizing activities among welfare recipients. The majority upheld dismissal because "[ $t$ ]he complaint in the instant action presents no facts to support the allegation that the refusal to refer children was in retaliation for [plaintiff's] organizing activities." Id. at 623. Judge Feinberg, dissenting, agreed that dismissal would be appropriate if the complaint "offered nothing more than [a] bald assertion," id. at 624 , but found that "the complaint is the antitlesis of the typically sparse, bare bones, conclusory pleading that might justify dismissal," id. at 625.

224. See, c.g., Leimer v. State Mut. Life Assurance Co., 108 F.2d 302, 306 (8th Cir. 1940) ("No matter how improbable it may be that [plaintiff] can prove her claim, she is entitled to an opportunity to make the attempt . . . .").

225. Jones v. Community Redevelopment Agency, 733 F.2d 646, 650 (9th Cir. 1984). But cf. Wade v. Johnson Controls, Inc., 693 F.2d 19, 22 (2d Cir. 1982) (allegation that employer failed to replace or repair defective air purification system with purpose of harming employees "not beyond the realm of possibility").

226. Haroco, Inc. v. American Nat'l Bank \& Trust Co., 747 F.2d 384, 404 (7th Cir. I984), aff'd on other grounds, 105 S. Ct. 3291 (1985).

227. See I0A C. Wright, A. Miller \& M. Kane, Federal Practice \& Procedure $\$ 2728$, at 178-86 (1983) (although convinced that should verdict be returned against movant at 
factual conclusions appears impossible to justify within the existing framework for pleadings decisions. As the following discussion demonstrates, the risks associated with heightened scrutiny of factual conclusions are not warranted even when limited to "suspicious" claims nor are they permissible as part of the trial court's discretion.

\section{Segregating Suspicious Claims-Toward DisCRETIONARY Dismissals?}

Since the new fact pleading cases seem to be limited to certain recurring situations symptomatic of the perceived drawbacks of the litigation boom, the new fact pleading might be cabined to a few limited categories of cases. A review of the likely categories shows, however, that none provides an adequate justification for applying stringent pleading requirements. The alternative of expanded trial court discretion to dismiss also fails. The problems of the litigation boom cannot so easily be shunted onto a special track.

\section{A. Disfavored Claims}

The classic justification for singling out some claims for onerous pleading requirements is that they are "disfavored."228 Malicious prosecution, for example, has long been viewed with disfavor because of its tendency to cause litigation to proliferate-making one lawsuit the basis for filing a second lawsuit.229 The critical point is that the disfavor is directed at the type of claim being asserted, not the risk that it may prove baseless. Federal courts adopting stricter scrutiny of factual conclusions often display somewhat similar disfavor for claims falling into the categories that have experienced the greatest increase in filings during the last twenty years. But the growth in filings provides insufficient justification for this treatment. ${ }^{230}$

The most common focus for disapproval are civil rights cases, but such claims should not be disfavored. To the contrary, they are central to our concept of liberty, and the Supreme Court has repeatedly emphasized their importance. ${ }^{231}$ Private enforcement has played a key

trial court would have to set aside verdict and order new trial, court has no discretion to grant summary judgment if there is dispute as to facts).

228. See 5 C. Wright \& A. Miller, supra note $3, \S 1296$, at 400 (disfavored claim idea an "old cliche").

229. See Prosser \& Keeton, supra note 52, at 876.

230. Cf. Dalton, Taking the Right to Appeal (More or Less) Seriously, 95 Yale L.J. 62,64 (1985) (caseload concerns alone provide insufficient justification for curtailing right to appeal); Redish, Book Review, 85 Colum. L. Rev. 1378, 1391 (1985) (increase in civil rights filings not a reason for limiting liberal interpretation of civil rights laws).

231. See, e.g., Bounds v. Smith, 430 U.S. 817, 828 (1977) ("the first line of defense against constitutional violations"). Thus, when Congress authorized the award of attorneys' fees to the prevailing party in civil rights litigation, the Court held that prevailing plaintiffs could recover almost automatically, see Newman v. Piggie Park Enters., 390 U.S. 400 (1968) (per curiam), but that defendants could only recover if the action werc 
role in accomplishing civil rights goals, ${ }^{232}$ so that antagonism toward assertion of this type of claim by private litigants cannot be justified.

Securities claims, the next most vilified category, are hardly disfavored. Many of the most important claims were implied by the courts themselves in order to accomplish the objectives of legislation that might not be enforced without private suits. ${ }^{233}$ Although the Supreme Court has cut back on implication of private remedies, it has also rejected efforts to impose a high burden of proof in actions under rule 10b-5, ${ }^{234}$ the most significant group of securities actions. Whatever their potential for abuse, securities fraud suits are not disfavored claims.

Similarly, although overbroad reading of the Sherman Act in favor of plaintiffs may frustrate its purposes, ${ }^{235}$ antitrust claims cannot be viewed as disfavored. Private antitrust suits were intended by Congress to serve an important function in deterring violation of the Sherman Act. ${ }^{236}$

A variant of the disfavored claims approach is the argument that the potential for harming a person's reputation that fraud claims present justifies heightened scrutiny in those cases. ${ }^{237}$ Similar arguments have been advanced concerning claims under RICO (involving charges that defendant is a "racketeer"), but it is difficult to say that the opprobrium connected with such claims is really greater than that attached to

brought vexatiously or in bad faith, see Christianburg Garment Co. v. EEOC, 434 U.S. 412 (1978). Marek v. Chesny, 105 S. Ct. 3012 (1985), alters the former result where the defendant makes a Rule 68 offer to compromise that plaintiff refuses, and plaintiff recovers less than the amount of the Rule 68 offer.

232. See, e.g., Brown v. Board of Educ., 347 U.S. 483 (1954); see also Norman, The Strange Career of the Civil Rights Division's Commitment to Brown, 93 Yale L.J. 983, 984 (1984) (After Brown, the federal government did little to enforce it, leaving enforcement to private suits.).

233. See, e.g., J.I. Case Co. v. Borak, 377 U.S. 426, 432 (1964) (action implied for violation of rules governing proxy solicitation because "[p]rivate enforcement of the proxy rules provides a necessary supplement to [Securties \& Exchange] Commission action").

234. See Herman \& MacLean v. Huddleston, 459 U.S. 375 (1983), in which the Court refused to apply the common law requirement that fraud be proved by clear and convincing evidence in a private action under Rule 10b-5 because "an important purpose of the federal securities statutes was to rectify perceived deficiencies in the available common-law protections by establishing higher standards of conduct in the securities industry." Id. at 389; cf. Eichler v. Berner, 105 S. Ct. 2622, 2628-29 (1985) (Court refuses to apply common law in pari delicto defense in federal securities fraud action).

235. Thus, the Antitrust Division of the Department of Justice has recently participated on behalf of defendants in antitrust cases, arguing against broad interpretations of antitrust law. See Marcus, Conflicts Among Circuits and Transfers Within the Federal Judicial System, 93 Yale L.J. 677, 707-08 n.187 (1984).

236. See, e.g., Bruce's Juices, Inc. v. American Can Co., 330 U.S. 743, 751-52 (1947); Javelin Corp. v. Uniroyal, Inc., 546 F.2d 276, 280 (9th Cir. 1976), cert. denicd, 431 U.S. 938 (1977).

237. See supra note 89 and accompanying text. 
others which do not invoke heightened pleading scrutiny.238 Accordingly, this basis for treating claims as disfavored seems unpersuasive as well.

It would surely be odd to treat the above claims as less favored than ordinary automobile torts that find their way into federal court due to diversity jurisdiction. Yet auto accident cases are clearly, under Form 9 , subject to minimal scrutiny at the pleading stage. The factors that may give civil rights, securities, or antitrust claims a high settlement value despite lack of merit result from problems endemic to the litigation system-such as broad discovery-and the fact that the content of the underlying substantive laws provide no easy handles for early resolution of claims. These difficulties, however, provide no basis for treating these claims as disfavored.

\section{B. Disfavored Litigants}

If the nature of the claim does not justify a hostile reception in the courts, it may be argued that the identity of the plaintiff or his lawyer does. But the categories suggested by the cases do not commend themselves as general standards. To the contrary, a review of these categories suggests that one should not single out cases for stricter pleading scrutiny by focusing on the characteristics of the participants.

1. The Repeat Player. - Although Professor Marc Galanter may be correct that most private parties are "one shot litigants," 239 some individuals distinguish themselves by suing frequently. ${ }^{240}$ The sheer

238. Judge Cardamone made this point well in his dissent in Sedima, S.P.R.L. v. Imrex Co., 741 F.2d 482 (2d Cir. 1984) (Cardamone, J., dissenting), rev'd, 105 S. Ct. 3275 (1985):

Today, defendants in civil suits are labelled as violators of environmental laws when pumping coal byproducts into the atmosphere, despoilers of our rivers when emptying oil from their tanker's bilges, adulterers in state divorce actions, and killers in vehicular wrongful death actions. The allegations of the civil complaint do not make these citizens criminals, although their conduct may well subject them to criminal prosecutions. Why the outcry over RlCO?

ld. at 508. In reversing, the Supreme Court appeared to agree with him. See $105 \mathrm{~S}$. Ct. at 3283 ("As for stigma, a civil RICO proceeding leaves no greater stain than do a number of other civil proceedings."); see also Herman \& McLean v. Huddleston, 459 U.S. 375, 390 (1983) ("The interests of defendants in a securities case do not differ qualitatively from the interests of defendants sued for violations of other federal statutes such as the antitrust or civil rights laws ....").

239. See Galanter, Why the "Haves" Come Out Ahead: Speculations on the Limits of Legal Change, 9 Law \& Soc'y Rev. 95, 97-114 (1974) (differentiating between litigants who are "one shotters" who have only occasional recourse to the courts, and "repeat players," who are involved in many similar litigations over time).

240. This is hardly a new phenomenon. Consider, for example, the following description of the "serious litigant" in 16th century England: "The serious litigant . . . . litigated as a matter of business practice, less with the intention of vindicating his rights than to obtain advantage over his opponent, bent upon bringing the adversary party to compromise or ultimately wearing him down to defeat and capitulation." Barnes, Star Chamber Litigants and Their Counsel, 1596-1641, in Legal Records and the Historian 
weight of past litigation sometimes prompts courts to curtail new filings by certain plaintiffs, particularly in prisoner suits, ${ }^{241}$ and a history of vexatious litigation is considered pertinent to sanctions for present abuse of litigation. 242 Given the concerns about the litigation boom, one might argue that courts should ask more of the repeat plaintiff at the pleading stage.

The fact that the plaintiff is a repeat litigant does not, standing alone, warrant stricter treatment. Consider, for example, Harry Lewis, perhaps America's leading corporate gadfly. Without attracting much public attention, Mr. Lewis, who often files derivative suits, has over the last decade brought literally dozens of suits, including at least one that reached the Supreme Court. ${ }^{243}$ He has not won all the cases, but he has occasionally obtained relief. While some judges have been suspicious about his litigation activities, ${ }^{244}$ it seems that in general he has not been found to have engaged in groundless litigation.245 Even though derivative actions may be viewed as peculiarly susceptible to abuse, ${ }^{246}$ the fact that a given plaintiff has filed many such actions does not necessarily show that he is abusing the litigation process.

There are two basic and related problems with subjecting the pleadings of repeat litigants to stricter scrutiny. First, the only possible relevance of a plaintiff's prior litigation activities is to show that he is

7, 22-23 (J. Baker ed. 1978). For recent examples see Franklin v. Murphy, 745 F.2d 1221,1231 n.13 (9th Cir. 1984) (plaintiff had filed over 100 separate actions); Demos v. Kincheloe, 563 F. Supp. 30 (E.D. Wash. 1982) (184 actions in three years).

241. See, e.g., Abdullah v. Gatto, 773 F.2d 487 (2d Cir. 1985) (leave of court needed for future filings); Urban v. United Nations, 768 F.2d 1497 (D.C. Cir. 1985) (injunction against filing suit in any federal court without prior approval of that court). Regarding the burden of prisoner suits, see infra note 269 .

242. See, e.g., Taylor v. Prudential-Bache Sec., Inc., 39 Fed. R. Serv. 2d (Callaghan) 1309 (N.D.N.Y. 1984) (Imposing Rule 11 sanctions on plaintiff said to "embody the paragon of harassing and vexatious litigation" on the basis of " $[t]$ he beleaguering saga of these and other Alan Taylor lawsuits.").

243. See Transamerica Mortgage Advisors, Inc. v. Lewis, 444 U.S. 11 (1979). Also, a leading corporate decision is the product of a Lewis lawsuit. See Aronson v. Lewis, 473 A.2d 805 (Del. 1984).

This author's research revealed that by the end of 1984, Mr. Lewis had been a named plaintiff in 43 reported federal cases, filed in seven different circuits, as wcll as eight reported state cases. The data are on file with the Columbia Law Revicw.

244. See Lewis v. Curtis, 671 F.2d 779, 782-83 (3d Cir. 1982), in which the district judge, before dismissing, queried Lewis" lawyer: "So you brought another strike suit, didn't you?" The appellate court reversed and ordered that another judge handle the case on remand. See id. at 789.

245. Professor Conard singles out Lewis v. Anderson, 615 F.2d 778 ( 9 th Cir. 1979), cert. denied, 449 U.S. 869 (1980), as an example of a sensible decision to terminate a derivative suit after the challenged action was ratified by shareholders and the shareholders' right to be consulted had thereby been vindicated. Conard, supra note 66 , at
$274-75$.

246. See, e.g., Brown v. Hart, Schaffner \& Marx, 96 F.R.D. 64, 67 (N.1). 1ll. 1982) ("Such lawsuits are the base work of rapacious jackals whose declared concern for cor"porate well-being camouflages their unwholesome appetite for corporate dollars."). 
the type of person who indulges in groundless litigation, supporting the inference that this litigation is also groundless. This is precisely the sort of relevance reasoning that is forbidden by the general prohibition against introduction of character evidence. ${ }^{247}$ Courts usually exclude evidence of prior litigation activity, in particular, as unduly prejudicial because dislike for the litigious is not a proper ground for deciding the merits of the current case. ${ }^{248}$

The second problem stems from the first. The inference regarding the litigant's character is only supportable if the past litigation was in fact groundless; the fact that plaintiff is a gadfly is not relevant to the merits of the current case. Accordingly, the court must determine whether the prior litigation was indeed groundless. Since one would presumably make such an inference only if there were several earlier cases, ${ }^{249}$ that determination could require more effort than deciding the instant case on its merits, a point that is reinforced by considering the difficulty of evaluating Mr. Lewis' past litigation. ${ }^{250}$ Partly to avoid such collateral issues, even where character evidence is allowed it is normally restricted to opinion or reputation evidence, rather than evidence of specific events. ${ }^{251}$

Inviting though it seems, then, the repeat player criterion is neither a useful nor a fair device for singling out cases for heightened scrutiny at the pleading stage. Even if it were, it would apply in a very small number of cases. If litigation abuse is confined to that small number of cases it is not so significant as many argue.

247. See Fed. R. Evid. 404(a) (excluding evidence of character to prove action in conformity therewith on a particular occasion).

248. See C. McCormick, McCormick on Evidence $\S 196$ (E. Cleary 3d ed. 1984); 1 D. Louisell \& C. Mueller, Federal Evidence $\$ 99$ (I977); cf. Crisafi v. Holland, 655 F.2d 1305,1309 (D.C. Cir. 1981) ("[A] complaint filed in forma pauperis is not subject to dismissal simply because the plaintiff is litigious. The number of complaints a poor person files does not alone justify peremptory dismissal.").

When prior claims are admitted in evidence, it is generally on the theory that they are so similar and numerous that they cast a shadow on the truthfulness of the present claim. For example, San Antonio Traction Co. v. Cox, 184 S.W. 722 (Tex. Civ. App. 1916), a suit for injuries allegedly sustained alighting from one of defendant's streetcars, involved 15 other claims by relatives of plaintiff for injuries allegedly received during the same year getting onto or off of defendant's streetcars. The court excluded the evidence because plaintiff had not been linked to the claims by his relatives, but stated that it would have allowed them had plaintiff himself made them. See also Mintz v. Premier Cab Ass'n, 127 F.2d 744 (D.C. Cir. 1942) (evidence admitted that plaintiff had previously made claim for injuries allegedly received while a passenger in a cab).

249. See D. Louisell \& C. Mueller, supra note 248 , § 99, at 735-36 (impeachment of claimant with evidence of "many recent, unsuccessful, similar claims" permissible but not where there is only "a single unsuccessful previous claim, even if it was highly similar").

250. See supra notes $243-45$ and accompanying text.

25l. See Fed. R. Evid. 405. 
2. The Disfavored Lawyer. - While most litigants are not repeat players, lawyers certainly are, ${ }^{252}$ and their prior litigation activities could affect the courts' attitudes toward their cases. Some courts have relied on such personal history in making important decisions. ${ }^{253}$ While courts have not explicitly based the dismissal of a pleading on a lawyer's history in prior litigation, this does not dispel the real experience of lawyers that judges view different lawyers differently. Nonetheless, for two important reasons challenges to the plaintiff's lawyer do not provide an appropriate basis-overt or covert-for stricter scrutiny of the pleadings.

First, there will be disputes about the lawyer's prior behavior. For example, consider I. Walton Bader, the attorney for plaintiff in Heart Disease Research Foundation v. General Motors Corp. ${ }^{254} \mathrm{Mr}$. Bader has had a number of clashes with judges during his career, ${ }^{255}$ and has recently been sanctioned by a judge who relied in part on this history. ${ }^{256}$ One could imagine that defendants might be tempted to attack Mr. Bader as part of an effort to have cases dismissed. The example of Mr. Bader, however, proves just how inappropriate a lawyer's prior behavior would be as a basis for dismissal. As will always be the case, there is another side: some view Mr. Bader as a vigorous, effective advocate. ${ }^{257}$ More

252. See Coffee, supra note 137 , at 18-19, 22-23 (referring to plaintiff's attorncys as repeat players and describing a "distinct subspecies" who are said to repeatedly file strike suits).

253. See, e.g., Eavenson, Auchmuty \& Greenwald v. Holtzman, 775 F.2d 535, 543 (3d Cir. 1985) (in imposing sanctions, district court referred to "a lot of harrassment" that lawyer had used in another case); Rogers v. Kroger Co., 669 F.2d 317, 319 (5th Cir. 1982) (district court dismissed action when plaintiff's attorney was unprepared to proceed, citing a prior case in which she had also been unprepared). It should be noted that the district court orders in both these cases were reversed.

254. 463 F.2d 98 (2d Cir. 1972); see supra notes 13-19 and accompanying text. Recall that the district court dismissed the suit as frivolous. See 15 Fed. R. Serv. 2d (Callaghan) 1517, 1519 (S.D.N.Y. 1972).

255. See In re Corrugated Container Antitrust Litig., 659 F.2d 1332, 1335 (5th Cir. 1981) (reporting lower court's finding that Bader had tried to disrupt multidistrict proceedings "by filing and threatening to file duplicative and harassing litigation"); Independent Investor Protective League v. Touche Ross \& Co., 607 F.2d 530, 534 n.5 (2d Cir.) (affirming discovery sanctions against Bader and characterizing his conduct as "utterly intolerable and reprehensible"), cert. denied, 439 U.S. 895 (1978); Slumbertogs, Inc. v. Jiggs, Inc., 353 F.2d 720, 720 (2d Cir. 1965) (affirming sanction of dismissal as appropriate "[i]n view of the dilatory and contumacious conduct of plaintiffs and their counsel in virtual defiance of the rules and orders of at least six judges in the district court"), cert. denied, 383 U.S. 969 (1969); Jackson v. Bader, 74 A.D.2d 621, 622, 424 N.Y.S.2d 926, 927 (1980) (listing examples of "I. Walton Bader's cavalier attitude towards the spirit and letter of the CPLR").

256. See In re Itel Sec. Litig., 596 F. Supp. 226, 235 (N.D. Cal. 1984) (referring to "Mr. Bader's history in this type of litigation"). For more background on this case, sec Riley \& Galante, Mr. Outside-A Fiasco Over Fees, Nat'l L.J., Nov. 19, 1984, at 1, col. 1.

257. See A Bondholder's Best Friend, Forbes, Dec. 15, 1975, at 41, 43 ("13ader's career reminds us of a story about Davy Crockett. As he travelled through Tennessec, a stranger asked why he was going to Texas, where he later fell at the Alamo. "To fight for 
generally, disputes about the lawyer's pedigree could, like examination of plaintiff's prior litigation, ${ }^{258}$ immerse the court in the merits of other lawsuits, hardly a helpful addition to burdensome motion proceedings. ${ }^{259}$

Second, even assuming that a lawyer's prior bad behavior can be established in some cases, it is perilous to ascribe that prior behavior to his current client, and it is that client's case that is subject to dismissal. ${ }^{260}$ However true it may be that the client is generally derivatively responsible for the lawyer's actions on his behalf,261 it hardly follows that the client is responsible for the lawyer's misdeeds in other cases.

3. The Poor. - The Federal Rules were designed, in part, to open up the federal courts to those of lesser means, and their moderate success in this regard may have caused courts to tighten pleading requirements for the poorest plaintiffs, indigents. Some courts fear such litigants because indigents seem to have nothing to lose by bringing groundless suits. ${ }^{262}$ Moreover, they often sue pro se, so that insistence on details may be more likely to reveal a fatal defect than in other cases, where a lawyer alert to the defect might try to elude detection through vagueness. The actual fate of most suits brought by the indigent-victories for plaintiffs are extremely rare ${ }^{263}$ - seems to justify suspicions that a particular indigent plaintiff cannot prove facts that merit relief.

Courts animated by such suspicions arguably have a statutory basis for treating pauper cases differently. The same statute that authorizes

my rights,' said Crockett."); The Numbers Game, Forbes, Apr. 1, 1974, at 54, 54 ("Walton Bader is the scourge of the U.S. accounting profession. A man whose name strikes fear in the hearts of senior partners in the big certified public accounting firms.").

258. See supra notes $249-51$ and accompanying text.

259. Cf. Becker, The Judge's Perspective, 51 Antitrust L.J. 437, 439 (1983) ("Now we will have Rule 11 hearings, and then we will have discovery on the Rule 11 issue. If you want to proliferate litigation, if you want to cause further delay, pass these rules because we will have sanctions hearings coming out of our ears . . . ."). But cf. Fed. R. Civ. P. 11 advisory committee note (Rule 11 discovery should only be conducted in "extraordinary circumstances" and a hearing may not be necessary).

260. Thus, when Rule 11 was amended in 1983 to put more teeth into sanctions against attorneys who abuse litigation, the amendment also deleted the provision authorizing the striking of the pleading. As the advisory committee notes explained, the power to strike "tended to confuse the issue of attorney honesty with the merits of the action." Fed. R. Civ. P. 11 advisory committee note. Cf. Risinger, Honesty in Pleading and Its Enforcement: Some "Striking" Problems with Federal Rule of Civil Procedure 1 1, 61 Minn. L. Rev. 1 (1976) (criticizing use of former Rule 11 to dismiss cases).

261. See Link v. Wabash R.R., 370 U.S. 626, 633-34 (1962) ("Petitioner voluntarily chose this attorney as his representative in the action, and he cannot now avoid the consequences of the acts or omissions of this freely selected agent.").

262. See, c.g., Franklin v. Murphy, 745 F.2d 1221, 1226 (9th Cir. 1984); Anderson v. Coughlin, 700 F.2d 37, 42 (2d Cir. 1982).

263. Prisoner suits, which constitute the bulk of pro se filings, result in judgment for the defendant in a very high proportion of the cases. A 1978 study reported that more than two-thirds of these suits are dismissed as groundless by the court without any response from defendant, and that only a very small number go to trial. Sce Turner, supra note 132 , at 617-18. 
waiver of filing fees in in forma pauperis cases also provides that the court may dismiss the complaint "if satisfied that the action is frivolous or malicious."264 Some courts feel that this power should not be exercised in any case that would survive a motion to dismiss under Conley $v$. Gibson, ${ }^{265}$ but others view the statute as allowing greater latitude in dismissing the action. ${ }^{266}$ The Supreme Court itself has clamped down on in forma pauperis petitions for certiorari, ${ }^{267}$ perhaps giving tacit support to the proponents of the more stringent treatment.

Carefully scrutinizing the factual conclusions alleged by the indigent is nevertheless hard to justify, as well as contrary to the objectives of the Federal Rules. The Supreme Court has repeatedly emphasized the need to take a liberal view of pro se pleadings, ${ }^{208}$ and the indigent are likely to be least able to ferret out the sort of proof the courts demand to support factual conclusions without first having some discovery. Moreover, despite widespread fear that courts will be inundated with such cases, their actual impact seems modest. ${ }^{269}$ Pleading practice

264. 28 U.S.C. $\$ 1915$ (d) (1982). The statute has so provided since it was enacted in 1892. Act of July 20, 1892, ch. 209, 27 Stat. 252. On the difficulty of defining frivolous, see Comment, Courts Are No Place for Fun and Frivolity: A Warning to Vexatious Litigants and Over-Zealous Attorneys, 20 Willamette L.J. 441, 446-48 (1984).

265. See e.g., Phillips v. Mashburn, 746 F.2d 782, 784 (1 lth Gir. 1984); Brandon v. District of Columbia Bd. of Parole, 734 F.2d 56, 59 (D.C. Cir. 1984); see also Turner, supra note 132, at 649 (arguing that courts should, at a minimum, use Conley v. Gibson standard).

266. See Franklin v. Murphy, 745 F.2d 1221, 1228 (9th Cir. 1984) (court can dismiss as frivolous although complaint states a claim if it is based on "wholly fanciful" factual allegations); Anderson v. Coughlin, 700 F.2d 37, 43 (2d Cir. 1983); cf. Spears v. McCotter, 766 F.2d 179 (5th Cir. 1985) (court may assign case to magistrate for evidentiary hearing to probe conclusory allegations and determine if case frivolous); Watson v. Ault, 525 F.2d 886 (5th Gir. 1976) (court may require plaintiff to respond to questionnaire to assist it in deciding if claim frivolous).

There does not appear to be historical support for broader dismissal under the statute than would be allowed had the plaintiff paid the fees, and very few cases were decided prior to the adoption of the Federal Rules in 1938. See O'Connell v. Mason, 127 F. 435,437 (D. Mass. 1903) ("It is possible that extreme cases might arise, where, looking only at the face of the declaration, the court might determine that the suit was frivolous or malicious even though the declaration were not demurrable."), affd, $132 \mathrm{~F}$. 245 (1st Cir. 1904).

267. See, e.g., Brown v. Herald Co., 464 U.S. 928 (1983) (denying motion for leave to proceed in forma pauperis). Four Justices dissented because review of such motions increases the Court's workload. See id. at 929-30 (Brennan, J., dissenting).

268. See, e.g., Boag v. MacDougall, 454 U.S. 364, 365 (1982); Hughes v. Rowe, 449 U.S. 5, 9 (1980). These cases follow Haines v. Kerner, 404 U.S. 519, 520 (1972), which stated that pro se complaints are subjected to "less stringent standards than formal pleadings drafted by lawyers."

269. See Eisenberg, Section 1983: Doctrinal Foundations and an Empirical Study, 67 Cornell L. Rev. 482, 526-33 (1982) (civil rights cases, including prisoner cases, iınpose modest burden); Turner, supra note 132, at 637-38, 647-49 (discussing expedited procedures used to process prisoner petitions); see also C. Seron, The Roles of Magistrates in Federal District Courts 44 (1983) (prisoner cases often assigned to magistrates). But cf. Ford v. Estelle, 740 F.2d 374 (5th Cir. 1984) (prisoncr cases cannot be 
in these cases may be more likely to elicit fatal details, but it is unlikely to provide a method for assessing factual conclusions. Like the repeat player, the poor plaintiff should not be shunted onto another track. ${ }^{270}$

\section{The Strike Suit Scenario}

Rather than focusing on the type of claim or identity of the plaintiff, a court could seek to isolate those cases that might be strike suits. Certainly the Supreme Court's opinion in Blue Chip Stamps v. Manor Drug Stores ${ }^{271}$ supports sensitivity to the risk of strike suits, and the concern over strike suits lies close to the heart of the malaise of the liberal ethos. ${ }^{272}$

The problem is identifying a strike suit. ${ }^{273}$ One feature often associated with strike suits is that the burden of litigation is sufficient to prompt the defendant to settle, despite the weakness of the plaintiff's claim, in order to avoid litigation expense or other disagreeable side effects of litigation, such as publicity or interference with an impending transaction. This concern is, of course, a reason for promoting pretrial decisions. ${ }^{274}$ It is of doubtful utility in singling out cases for stricter pleading treatment, however, because there is no intrinsic relation between litigation expense or other disagreeable side effects of a lawsuit and the absence of merit in plaintiff's case. Litigation expense, for example, results from the need to do extensive preparation for trial, and may make a small claim that is assured of success on the merits into a nuisance suit, that is, one where litigation costs outweigh expected recovery. ${ }^{275}$ Similarly, the fact that the suit may delay a transaction provides no basis for dismissing the suit if the proposed transaction itself is

assigned to magistrates for trial without parties' consent). Moreover, the assertion of groundless claims may not be cost free for the petitioner. See Tasby v. United States, 504 F.2d 332 (8th Cir. 1974) (prosecution for perjury in connection with prisoner petition).

270. Except for in forma pauperis situations, there is normally no occasion for plaintiffs to disclose their financial condition to the court. Even if there were, there is no standard by which to decide who is sufficiently poor for this unfavorable treatment.

271. 421 U.S. 723 (1975); see supra notes 58-60 and accompanying text.

272. Such concerns surface in decisions to limit discovery. See, e.g., Aviation Specialties, Inc. v. United Technologies Corp., 568 F.2d 1186, 1190 (5th Cir. 1978) (describing plaintiff's interrogatories as "nothing more than a thinly veiled attempt to enhance the strike capability of its suit"). Defendants can play this game also. See Blake Constr. Co. v. International Harvester Co., 521 F. Supp. 1268, 1270 (N.D. Ill. 1981) (referring to "Stalingrad defense").

273. See Pennsylvania Gas \& Water Co. v. Federal Power Comm'n, 427 F.2d 568, 576 (D.C. Cir. 1970) ("Much that is sound and prophylactic in corporate law was developed in so-called strike suits . . . ."); W. Cary \& M. Eisenberg, Cases and Materials on Corporations 888 (5th ed. 1980) ("The strike suit . . . may very well be no more than an over-the-hill dragon, puffed into life to frighten the courts away from deciding substantive issues.").

274. Sce supra notes $134-42$ and accompanying text.

275. See Rosenberg \& Shavell, supra note 141, at 4 . 
illegal. Moreover, there is no standard by which litigation inconvenience is to be gauged; every defendant finds litigation burdensome.

The key factor, then, is the weakness of the claim. Where the focus is on a factual conclusion, however, the court is without a reliable way of identifying cases in which plaintiffs are likely to prevail. ${ }^{276}$ On balance, the strike suit scenario simply authorizes judges to dismiss cases they view as weak when it appears to them that the litigation will unduly inconvenience the defendant. ${ }^{277}$

\section{Discretionary Dismissals}

The problems with the strike suit scenario suggest another approach-granting judges discretion to dismiss suits they conclude are suspicious. The classic approach is that trial judges have no discretion; any dismissal for failure to state a claim is subject to full review, and the trial judge's decision is accorded no deference whatsoever.278 Perhaps this rule should be relaxed, and an abuse of discretion standard of review substituted. 279 This approach might allow judges to consider a variety of factors including those discussed above, and to impose stricter pleading standards when a case fits an abusive litigation profile.

Such a change in pleading doctrine would be consistent with the current trend across a spectrum of trial administration issues. The Federal Rules of Evidence, for example, largely rely on the exercise of sensible discretion by the trial court in admitting or excluding evidence. ${ }^{280}$ The case management movement, fueled by the 1983 amendments to the Federal Rules of Civil Procedure, similarly emphasizes the importance of discretionary decisions on such matters as timing and scope of

276. See supra notes 196-227 and accompanying text.

277. It may even invite unwanted and irrelevant speculation about plaintif's motives. For example, in Grant v. Smith, 574 F.2d 252 (5th Cir. 1978), the district court dismissed a housing discrimination action after a trial to the court without a jury, noting that plaintiffs seemed more interested in a strike suit than in securing accomodations. Id. at 255. The appellate court reversed because of the district court's emphasis on plaintiffs' good faith, which it found irrelevant to the question whether there was forbidden discrimination. Id.

278. See, e.g., Kelson v. City of Springfield, 767 F.2d 651, 653 (9th Cir. 1985).

279. The classic analysis of this standard is Rosenberg, Judicial Discretion of the Trial Court, Viewed From Above, 22 Syracuse L. Rev. 635 (1971). For a careful examination of the types of treatment that an appellate court can adopt for discretionary trial court decisions, broadly characterized as delegation and deference, see Post, The Management of Speech: Discretion and Rights, 1984 Sup. Ct. Rev. 169, 208-19.

Interestingly, early advocates of notice pleading seemingly viewed discretion as an antidote to the tendency of appellate courts of that era to invent new pleading nicetics under the Codes. Thus, Professor Whittier, writing in 1918 to urge adoption of noticc pleading, expressed "hope[1 that no law would develop determining what is sulficient notice of any cause of action or defense. It should be left a question of fact in each casc to be determined by the trial judge . . ." Whitticr, supra note 111 , at 505 .

280. See Waltz, Evidence is Dead, Wigmore Obsolescent: Long Live Judicial Discretion!, 65 Chi. B. Rec. 284 (1984). 
discovery, which can have a very great impact on a party's ability to prepare and present his case. ${ }^{281}$ Perhaps most analogous is the handling of the demand on directors requirement for derivative actions under Rule 23.1-also governed by an abuse of discretion standard. ${ }^{282}$

Expanded trial court discretion may indeed be the emerging reality of trial court handling of pleadings motions. In Heart Disease Research Foundation v. General Motors Corp. ${ }^{283}$ for example, the Second Circuit said the trial court had discretion to dismiss conclusory claims of conspiracy. ${ }^{284}$ More significantly, trial judges are sometimes allowed to direct plaintiffs to replead even though the case would not be subject to dismissal, and to enforce this order by dismissing if the plaintiff does not comply. ${ }^{285}$ Other cases suggest that appellate courts are coming to regard the handling of pleadings motions as such individualized matters that consistency among decisions, the hallmark of an issue of law, is not critical. Thus, in a 1978 decision affirming the dismissal of a securities fraud shareholders' class action, the Second Circuit was unmoved by the fact that the same plaintiff, represented by the same lawyer, had been allowed to proceed with another complaint of virtually identical specificity. Instead, it disdained any effort to reconcile a welter of dismissal cases: "We see no profit in attempting to analyze these decisions, which may or may not be consistent and each of which necessarily rests on its particular facts." 286 With their emphasis on early "issue definition" and early disposition of groundless claims and defenses, the 1983 amendments are likely to accelerate this trend toward discretion. ${ }^{287}$

281. See supra notes 61-62 and accompanying text. But consider Friendly, Indiscretion About Discretion, 31 Emory L.J. 747, 755 (1982): "If we have been moving increasingly in the direction of seeking justice in the individual case by more general rules and grants of dispensing power . . . restrictions upon review of such decisions made by courts of first instance are increasingly unacceptable."

282. See Lewis v. Graves, 701 F.2d 245, 248 (2d Cir. 1983).

283. 463 F.2d 98 (2d Cir. I972).

284. See supra note 16 and accompanying text.

285. For a recent example, see Friedlander v. Nims, 755 F.2d 810 (11th Cir. 1985), a class action alleging RICO and securities fraud claims. One defendant moved to dismiss, and the trial court dismissed with leave to amend on the ground that the complaint failed to plead fraud with particularity as required by Rule 9(b). When plaintiff did not amend, the trial court dismissed with prejudice. The appellate court affirmed the dismissal as a sanction, but carefully noted that it was not holding that the original complaint was subject to dismissal without leave to amend. See id. at 814 n.6. However logical this treatment is, it raises the prospect that a trial court could establish a predicate for dismissal with prejudice by ordering plaintiff to provide more specifics to support a claim not subject to dismissal with prejudice as originally pleaded.

286. Denny v. Barber, 576 F.2d 465, 470 (2d Cir. 1978). The other case is Denny v. Carey, 72 F.R.D. 574 (E.D. Pa. 1976).

287. Precisely this possibility has engendered much concern among commentators. Sce, e.g., Sherman, Book Review, 63 Tex. L. Rev. 721, 729-32 (1984). Nonetheless, there is some suggestion that even substantive decisions may be subject to trial court discretion under RICO. See Bankers Trust Co. v. Rhoades, 741 F.2d 511, 518 n.7 (2d 
Although some relaxation of the idea that trial judges have no discretion in connection with pleading decisions may be inevitable, discretion is no panacea for handling the kind of factual conclusions that have created the problem. First, increased discretion in this area runs squarely against the grain of the Federal Rules. It is one thing to argue for expanded power to resolve pleadings matters in order to assure litigants an opportunity for a decision on the merits. It is quite another to authorize a judge to decide cases on instinct. ${ }^{288}$ That is not what we mean when we endorse a merits decision.

Second, giving increased discretion to judges would disregard the very real attitudinal differences among judges. With the growth of case management, there can be little doubt that individual differences among judges make the assignment of the case very important to the way it develops in the pretrial stage, but differences in attitude toward such matters as timing and breadth of discovery do not threaten the substantive law. It is hard to deny, however, that at least some judges view certain types of claims, although they are provided for under law, as unimportant; ${ }^{289}$ to increase discretion to dismiss could lead to judge-by-judge "disfavored claims" treatment, surely less desirable than the disfavored claim theory discussed above. ${ }^{290}$ Such action would threaten to fragment the substantive law by permitting judges to create their own requirements for various kinds of claims. Present practice already makes such diversity unavoidable to some extent. To illustrate, one district judge has suggested that it is practical for litigants in RICO cases to tailor their allegations to the known predilections of the judge to whom the case is assigned. ${ }^{291}$ Although that

Cir. 1984) ("The matter of whether given conduct should be considered one or more than one 'predicate act' is a matter best left, in the first instance, to the discretion of the district judge."), vacated, 105 S. Ct. 3550 (1985); cf. Willamette Sav. \& Loan v. Blake \& Neal Fin. Co., 577 F. Supp. 1415, 1430 (D. Or. 1984) (regarding supposed requirement of an independent racketeering injury, court observes that "[c]ourts recognize a racketeering injury when they see it," citing Justice Stewart's observation about obscenity that "1 know it when 1 see it"); Waste Recovery Corp. v. Mahler, 566 F. Supp. 1466, 1468 (S.D.N.Y. 1983) (same).

288. Cf. Resnik, supra note 44 , at $840-41$ (discussing outrage caused by judge's decision based on a coin flip).

289. Recall, for example, the hearings on the nomination of G. Harrold Carswell to the Supreme Court, in which it was reported that as a district judge he had regularly dismissed civil rights actions and been reversed. See $11 \mathrm{R}$. Mersky \& J. Jacobstein. The Supreme Court of the United States: Hearings and Reports on Successful and Unsuccessful Nominations of Supreme Court Justices by the Senate Judiciary Committee, 1916-1972, at 117-23 (1975) (testimony of Gary Orfield); id. at 139-47 (testimony of John Lowenthal); id. at 177-82 (testimony of Norman Knopf); id. at 22 1-33 (testimony of Leroy Clark); id. at 282-93 (testimony of Joseph Rauh). In particular, Prolessor Orfield pointed up one case as an "example of [Judge Carswell's] willingness to use his discretion as a district judge to even strike out [an] argument on a very important issttc raised by the litigants." Id. at I 19.

290. See supra notes $228-38$ and accompanying text.

291. Speech by Milton Shadur before the Illinois Institute on Continuing legal lid- 
suggestion results in part from the present diversity of interpretations of RICO, it also shows how individualized "justice" could become if greater discretion to dismiss on the pleadings were to become accepted practice.

Third, there is simply no reason to believe that a trial judge is well equipped for this task, whether experienced or not. One supposed hallmark of a discretionary decision is that the trial judge is better positioned to decide the matter than appellate judges looking at a cold record.292 That is simply not true in a meaningful way with respect to factual conclusions in pleadings. At the pleading stage, the judge has had no exposure to the parties or to evidentiary material. Instead, he has only seen the pleadings and dealt with the lawyers. On the basis of this information, it is impossible for him to form reliable conclusions about whether given defendants have conspired to violate the antitrust laws, discriminated against the plaintiff on grounds of race, or failed to make a full disclosure in connection with the purchase or sale of securities. Yet these are precisely the types of issues that trial judges are resolving using the vehicle of fact pleadings. ${ }^{293}$ Admittedly judges must make a similar determination at the summary judgment stage, but that decision is at least based on evidentiary material. ${ }^{294}$ At the pleading stage the judge must guess whether the plaintiff, if allowed discovery, will be able to gather evidence to support his claims. Uninformed judicial speculation is not an adequate means of arriving at correct decisions on the merits.

Finally, enhancing the importance of selection of the judge would encourage judge shopping. There can be no doubt that there are already incentives for judge shopping and that our courts seek to prevent it.295 To endorse merits decisions that reflect the individual preferences of the judges involved, however, would tend to undermine the notion that parties can expect evenhanded, and roughly equal, justice from any judge. ${ }^{296}$ However doubtful that assumption may be in real-

ucation (Jan. 30, 1985) (unpublished) (on file at the offices of the Columbia Law Review):

Once the case is assigned, ... both lawyers should immediately run the judge's name and the RICO acronym on Lexis or Westlaw. . . . Once you've taken that judicial research step, unless the judge is such a maverick that you have to play your case for the Court of Appeals from the beginning, it is obviously judicious on your part to adapt to what our sponsors [of the program] . . . call the "judicial perspective."

292. See Rosenberg, supra note 279 , at $663-65$.

293. See supra notes $84-104$ and accompanying text.

294. Fed. R. Civ. P. 56(e) requires that affidavits submitted on summary judgment motions be made on personal knowledge and set forth facts admissible in evidence. For a discussion of the alternative of summary judgment treatment, see infra notes 297-342 and accompanying text.

295. See Marcus, supra note 235, at 706-07 n.183.

296. Cf. In re Cement Antitrust Litig., 673 F.2d 1020, 1027 (9th Cir. 1982) ("[I]t is difficult for us to think of a question which is more separable from and collateral to the 
ity, it could not be sustained were judges explicitly authorized to indulge their prejudices on the merits. Such a system would overtly tie the outcome of the case to the assignment, and one could only hypocritically contend that efforts to influence the assignment of the case are improper.

Accordingly, the solution to the problem of litigation abuse does not lie in the direction of increasing the discretion of the trial judges to dismiss cases because they sense misuse of the litigation system. Such a development could undermine the substantive law just as fully as failure to dismiss meritless suits.

\section{The Summary Judgment Route}

The fact that a case is not dismissed does not mean that it can only be resolved on the merits by a full dress trial. To the contrary, the intermediate step of summary judgment exists precisely to enable courts to examine the factual conclusions of the pleader and determine whether they are supported by sufficient evidence to warrant the time and effort of a trial. Moreover, summary judgment works both ways; plaintiffs can also use it to obtain a merits disposition. Indeed, summary judgment was originally adopted in England to enable plaintiffs to penetrate groundless defenses. ${ }^{297}$ Summary judgment was the stage that Clark himself hoped would flourish as the mechanism for pretrial disposition of cases, ${ }^{298}$ but the early experience under Rule 56 failed to achieve Clark's desire. Clark's own Second Circuit, over his objections, adopted a "slightest doubt" standard, which resembled the dismissal standard later articulated in Conley $v$. Gibson: summary judgment should be denied whenever there is the slightest doubt about the entitlement of the moving party to judgment. 299 Moreover, in I962 the Supreme Court cautioned that summary judgment should be "used sparingly in complex antitrust litigation where motive and intent play leading

merits" than recusal of one judge.), affd sub nom. Arizona v. Ash Grove Cement Co., 459 U.S. 1190 (1983); Hampton v. City of Chicago, 643 F.2d 478, 479 (7th Cir. 1981) ("While plaintiffs have a right to have their claim heard by the district court, they have no protectable interest in the continued exercise of jurisdiction by a particular judge.").

297. Louis, Federal Summary Judgment Doctrine: A Critical Analysis, 83 Yale L.J. 745,745 (1974).

298. Smith, supra note 3 , at $918-19,929$.

299. See, e.g., Arnstein v. Porter, 154 F.2d 464, 468 (2d Cir. 1946); Dochler Metal Furniture Co. v. United States, 149 F.2d 130, 135 (2d Cir. 1945). See generally Louis, supra note 297 , at 760-62 (concluding that slightest doubt standard made summary judgment unavailable on facts where moving party would be entitled to a directed verdict). This standard has been labelled "plainly wrong." Sonenshein, State of Mind and Credibility in the Summary Judgment Context: A Better Approach, 78 Nw. U.L. Rev. 774,798 (1983). For a discussion of Clark's opposition to this standard, see Smith. supra note 3, at 930-31. For a discussion of the contrasting views of Judge Jerome Frank, the architect of the slightest doubt standard, see R. Glennon, The lconoclast as Reformer 156-57 (1958). 
roles." 300

Limitations on summary judgment were particularly troublesome in the kinds of cases that came to typify the new litigation boom precisely because those cases were often complex and turned on issues of motive and intent. ${ }^{301}$ Hence, restrictions on summary judgment may have acted as a catalyst for the reemergence of fact pleading. Certainly, the Second Circuit's refusal to credit plaintiffs' allegations that defendants were or should have been aware of the dangers of the Dalkon Shield in Ross v. A.H. Robins Co. ${ }^{302}$ shows that the "slightest doubt" standard was not being employed in the pleading context. The juxtaposition of these developments was ironic: at the pleading stage, plaintiffs might be denied discovery altogether unless they could offer facts giving rise to a "strong inference" 303 supporting their factual conclusions; thereafter, plaintiffs who had access to discovery were indulged with great laxity at the summary judgment stage under the slightest doubt view. This seems backwards.

The tendency toward this ironic result has abated over recent years as limitations on summary judgment have relaxed. ${ }^{304}$ In 1968, the Supreme Court signalled greater flexibility in the handling of summary judgment in antitrust cases, ${ }^{305}$ and circuit courts have since upheld

300. Poller v. Columbia Broadcasting Sys., 368 U.S. 464, 473 (1962).

301 . See supra text following note 105 .

302. 607 F.2d 545 (2d Cir. 1979), cert. denied, 446 U.S. 946 (1980); see supra notes $91-93$ and accompanying text.

303. See supra notes $93,219-23$ and accompanying text.

304. For examples, see infra notes 305-307 and accompanying text. See generally Louis, Summary Judgment and the Actual Malice Controversy in Constitutional Defamation Cases, 57 S. Cal. L. Rev. 707, 709-10, 715 n.49 (1984) (discussing shift away from Poller $v$. CBS and absence of articulated new rules); Sonenshein, supra note 299, at 778-79 (1963 amendment to Rule 56 expanded availability of summary judgment); Booker, Summary Judgment Proves Versatile Antitrust Tool, Legal Times, Feb. 14, 1983 , at 17, col. 1 (growing availability of summary judgment in antitrust cases). For a strategy for such decisions see Schwarzer, Summary Judgment Under the Federal Rules: Defining Genuine Issues of Material Fact, 99 F.R.D. 465 (1984).

This is not to say that trial judges now have a free hand to grant summary judgment. See Wechsler v. Steinberg, 733 F.2d 1054, 1058-59 (2d Cir. 1984) (reversing summary judgment for defendant accountants in securities fraud action because "[i]ssues of motive and intent are usually inappropriate for disposition on summary judgment"); Neubauer, Snyder \& Nolan, Judges Compare Courts, 11 Litig., Spring 1985, at 10, 15 (district judge explains that "[w]bat with the track record that district judges have in this circuit on the subject of summary judgment . . . . [granting summary judgment] is a high-risk judicial decision, as we all know"). But cf. Schwarzer, supra, at 467 \& n.9 (reporting that in fact summary judgments are reversed less frequently than most judgments in Ninth Circuit).

305. See First Nat'l Bank v. Cities Serv. Co., 391 U.S. 253, 288-90 (1968). Tle Court upheld summary judgment in favor of defendant in an antitrust case, adding:

While we recognize the importance of preserving litigants' rights to a trial on their claims, we are not prepared to extend those rights to the point of requiring that anyone who files an antitrust complaint setting forth a valid cause of 
summary judgment on the issue of whether there was a conspiracy. ${ }^{306}$ The Supreme Court has gone further in civil rights cases and encouraged summary disposition of suits against government officials on the defense of qualified immunity, ${ }^{307}$ an issue that turns in part on state of mind. ${ }^{308}$

Rather than indulging all possible doubts in favor of the opponent to summary judgment, the courts seem to be shifting emphasis toward ensuring an adequate opportunity for discovery and then scrutinizing the fruits of that discovery. But the defendant can move for summary judgment at any time, and may do so at the beginning of the case in conjunction with a motion to dismiss. ${ }^{309}$ At that point, the plaintiff is in no better position to oppose summary judgment than he is to include detailed evidence in the complaint in response to stringent fact pleading requirements. The plaintiff can, however, request under Rule 56(f) that the summary judgment motion be postponed while he obtains discovery necessary to rebut the defendant's showing. ${ }^{310}$ The focus should shift, then, to application of Rule 56(f).

A plaintiff is not automatically entitled to a Rule $56(f)$ postponement. Plaintiff must show that by exercising reasonable diligence he could not have previously obtained evidence to controvert the defendant's showing. ${ }^{311}$ Although this requirement may often be easy for the

action be entitled to a full-dress trial notwithstanding the absence of any significant probative evidence tending to support the complaint.

Id. at 290. In dissent, Justice Black argued that the decision could not be squared with Poller $v$. CBS. Id. at 303-05.

306. See, e.g., Barnes v. Arden Mayfair, Inc., 759 F.2d 676 (9th Cir. 1985); Products Liab. Ins. Agency, Inc. v. Crum \& Forster Ins. Cos., 682 F.2d 660 (7th Cir. 1982); Parsons v. Ford Motor Co., 669 F.2d 308 (5th Cir.), cert. denied, 459 U.S. 832 (1982). Cf. Matsushita Elec. Indus. v. Zenith Radio Corp., 54 U.S.L.W. 4319, 4322-25 (U.S. Mar. 26, I985) (where defendants lacked rational economic motive to conspire, defendants entitled to summary judgement unless plaintiffs show unambiguous evidence that tends to exclude the possibility that defendants acted independently).

307. See Harlow v. Fitzgerald, 457 U.S. 800, 813-19 (1982).

308. Interestingly, the Court's method for promoting summary disposition was to introduce an objective reasonable person standard in place of a subjective standard looking to defendant's actual state of mind. See Mitchell v. Forsyth, 105 S. Ct. 2806, 2810-11 (1985); Harlow v. Fitzgerald, 457 U.S. 800, 818 (1982). For criticism of this approach, see Note, Qualified Immunity for Government Officials: The Problem of Unconstitutional Purpose in Civil Rights Litigation, 95 Yale L.J. 126 (1985).

309. In fact, if on a motion to dismiss the pleadings, the defendant submits and the court does not exclude matters outside the plaintiff's pleading, the court must convert the motion to one for summary judgment. See Fed. R. Civ. P. 12(b).

310. See Fed. R. Civ. P. 56(f):

Should it appear from the affidavits of a party opposing the motion that he cannot for reasons stated present by affidavit facts essential to justify his opposition, the court may refuse the application for judgment or may order a continuance to permit ... depositions to be taken or discovery to bc had . . . .

311. See, e.g., Pfeil v. Rogers, 757 F.2d 850, 857 (7th Cir. 1985) (upholding rejection of Rule 56(f) request because plaintiffs' claim they could not earlier have obtained information "strain[ed] credibilty"). 
plaintiff to satisfy at the outset of the lawsuit, sometimes it is not. For example, in a recent securities fraud action the Seventh Circuit upheld summary judgment against plaintiffs who had been denied access to discovery because defendants' motion was based on the statute of limitations and the only issue was the date on which plaintiffs were aware of sufficient facts to put them on notice of the claim. ${ }^{312}$ Defendants relied on plaintiffs' depositions, and the court of appeals rejected the argument that summary judgment should be deferred pending discovery by plaintiffs because " $[t]$ he plaintiffs were the only people who would possibly be in possession of information sufficient to counter the inferences of a lack of due diligence found in their depositions."313

The plaintiff must also show that the requested discovery is likely to provide grounds for denying the motion, ${ }^{314}$ a requirement said to apply even where the information sought is exclusively in the defendant's possession. ${ }^{315}$ The court need not credit speculation that some controverting facts might be discovered. As one court explained, "[i]t is not enough [for the plaintiff] to rest upon the uncertainty which broods over all human affairs or to pose philosophic doubts regarding the conclusiveness of evidentiary facts." 316 There should be some articulated justification for expecting the discovery to unearth evidence that will rebut the defendant's showing.

Evaluating the plaintiff's justification may, however, prove extremely difficult. For example, in Decker v. Massey-Ferguson Ltd., ${ }^{317}$ where the Second Circuit upheld dismissal of the plaintiff's securities complaint based on a comparison of plaintiff's allegations with the contents of various reports issued by Massey, it might well be that had the defendants' motion been treated as one for summary judgment there would have been no need for discovery. Certainly, the appellate court's conclusions that Massey's filings showed conclusively that its forecasts

312. See Gieringer v. Silverman, 731 F.2d 1272 (7th Cir. 1984).

313. Id. at 1278 .

314. See United States ex. rel. Small Business Admin. v. Light, 766 F.2d 394, 397-98 (8th Cir. 1985); Willmar Poultry Co. v. Morton-Norwich Prods., 520 F.2d 289, 297 (8th Cir. 1975), cert. denied, 424 U.S. 915 (1976); see also Reasor v. City of Norfolk, 606 F. Supp. 788, 792 (E.D. Va. 1984) (court granted Rule 56(f) request but cautioned plaintiffs' attorneys that they might be sanctioned if they did not thereafter timely comply with Rule 11). If the information that the plaintiff seeks is not relevant to the motion, the court should proceed to rule. See First Jersey Nat'l Bank v. Dome Petroleum, Ltd., 723 F.2d 335, 341 \& n.4 (3d Cir. 1983); Exxon Corp. v. FTC, 663 F.2d 120, 126-29 (D.C. Cir. 1980).

315. See Weir v. Anaconda Co., 773 F.2d 1073, 1083 (10th Cir. 1985); 6 Moore's Federal Practice, supra note 40, I 56.24, at 56-1432.

316. Robin Constr. Co. v. United States, 345 F.2d 610, 614 (3d Cir. 1965); accord Neely v. St. Paul Fire \& Marine Ins. Co., 584 F.2d 341, 344 (9th Cir. 1978) ("An opposing party's mere hope that further evidence may develop prior to trial is an insufficient basis upon which to justify denial of the motion.").

317. 681 F.2d 111 (2d Cir. 1982); see supra notes 196-207 and accompanying text. 
were not actionable ${ }^{318}$ and that Massey had complied with applicable SEC requirements ${ }^{319}$ suggest this result. But the court's reliance on "unchallenged" figures in Massey's reports to show that plaintiff was wrong in claiming Massey's statements were false ignores the possibility that discovery might have enabled plaintiff to challenge these figures. 320 The possibility, however, need not cause the court to pause unless there were some reasonable prospect that discovery would in fact provide a basis for challenging the figures, and the plaintiff has the burden of specifying why that is true. At some point the off chance that incriminating evidence might surface through discovery is not enough to shake the court's confidence that, as the Second Circuit held in the dismissal posture in Decker, there is no legitimate claim against defendants.

Contrast, however, Ross v. A.H. Robins Co. ${ }^{321}$ in which the Second Circuit rejected the plaintiff's allegations about defendants' awareness of the risks of the Dalkon Shield. Shifted into the summary judgment context, that case presents a situation in which a court could not reasonably conclude that the defendants were free of the alleged awareness without allowing some discovery. In fact, discovery is usually necessary to give plaintiff access to controverting evidence on state of mind issues.

The proper focus here, as with merits decisions on dismissal motions, ${ }^{322}$ is on the level of confidence that the defendant has not violated the plaintiff's rights. A court may be more comfortable in granting summary judgment for the defendant than in deciding dismissal motions in defendant's favor because summary judgment can be granted, even if the plaintiff makes no showing in opposition, only where the defendant has affirmatively demonstrated that there are no disputed issues of fact. ${ }^{323}$

Rule 56(f) requests, however, generally should be liberally

318. See supra note 202 and accompanying text.

319. See id.

320. See supra note 203 and accompanying text.

321. 607 F.2d 545 (2d Cir. 1979), cert. denied, 446 U.S. 946 (1980); see supra notes $91-93$ and accompanying text.

322. See supra notes $144-95$ and accompanying text.

323. See, e.g., Adickes v. S.H. Kress \& Co., 398 U.S. 144, 160 (1970); First Nat'l Bank v. Cities Serv. Co., 391 U.S. 253, 289 (1968). Thus, in Catrett v. Johns-Manville Sales Corp., 756 F.2d 181 (D.C. Cir.), cert. granted sub nom. Celotex Corp. v. Catrctt, $106 \mathrm{~S}$. Ct. 342 (1985), the court reversed the grant of summary judgment to defendant because defendant had made no showing in support of its motion even though it appeared that plaintiff (who had the burden of proof) had no admissible evidence to oppose the motion. Judge Bork dissented, arguing that summary judgment is permissible where the plaintiff has no evidence. 1d. at 187-91. It is possible the Supreme Court may' use this case as a vehicle for revising the rule on this issuc. Cf. Fontenot v. Upjoln Co., 780 F.2d 1190, 1197 (5th Cir. 1980) (rejecting decision of D.C. Circuit in Calrell). 
granted. ${ }^{324}$ Nonetheless, they need not raise the spectre of voluminous discovery. To the contrary, Rule 56(f) contemplates only limited discovery, ${ }^{325}$ and the plaintiff's showing under Rule 56(f) should focus that discovery effort. Moreover, the court could authorize such discovery in stages, reviewing the results of one stage before deciding whether to authorize another. ${ }^{326}$ Such scrutiny of discovery results is well adapted to the emerging case management orientation of federal judges; discovery can be directed toward critical issues and assessed as it is completed to determine whether summary disposition of part or all of the case is then possible. ${ }^{327}$ Although excessive limitations may generate unnecessary disputes about the scope of discovery, ${ }^{328}$ the court's power to tailor the discovery to the needs of the case limits the litigation boom risks that apparently prompted courts to adopt stringent fact pleading requirements in the first place. ${ }^{329}$ In cases like Decker, the decision whether to allow any discovery may be extremely difficult, but if the Rule 56(f) issue is framed in terms of confidence that the defendant has not violated the plaintiff's rights, the court will at least be addressing the right basic problem.

Unfortunately, some courts seem instead to take the same approach as the new fact pleading cases and deny Rule 56(f) requests because the plaintiff presently lacks evidence, even though the issue seems to call for discovery. In Paul Kadair, Inc. v. Sony Corp. ${ }^{330}$ for example, the Fifth Circuit recently upheld summary judgment that defendants had not conspired even though the trial court had unilaterally stayed discovery before plaintiff had taken any. Plaintiff, a stereo retailer, sued forty-one manufacturers, distributors, and retailers of elec-

324. See, e.g., Patty Precision, Inc. v. Brown \& Sharpe Mfg., 742 F.2d 1260, 1264 (10th Cir. 1984); 10A C. Wright \& A. Miller, supra note 3, § 2740, at 530-32.

325. See First Nat'l Bank v. Cities Serv. Co., 391 U.S. 253, 265 (1968) ("comparatively limited discovery"); see also id. at 298 ("discovery obtainable under Rule 56(f) . . . would normally be less extensive in scope").

326. For a discussion of such a process in a related context, see Durham \& Dibble, Certification: A Practical Device for Early Screening of Spurious Antitrust Litigation, 1978 B.Y.U. L. Rev. 299. In Reiter v. Sonotone Corp., 442 U.S. 330 (1979), the Court cited this article with apparent approval while observing that "[d]istrict courts must be especially alert to identify frivolous claims brought to extort nuisance settlements ... Id. at 345 .

Plaintiff's attorneys may have an incentive to screen discovery results in this fashion by themselves. Professor Coffee suggests that they may lose interest in cases in which limited discovery does not turn up a "smoking gun." See Coffee, supra note 136. To the extent he is correct, the courts may feel less need to intervene in the process.

327. For a discussion of such control of discovery, see W. Schwarzer, Managing Antitrust and Other Complex Litigation § 3-3, at 62-63 (1982). Limitations on discovery can cause problems of their own, however. See Shaklee Corp. v. Gunnell, 748 F.2d 548 (10th Cir. 1984) (limitations on discovery denied defendants due process when matters deemed irrelevant during discovery became relevant during trial).

328. See $10 \mathrm{~A}$ C. Wright \& A. Miller, supra note $3, \S 2740$, at 541 .

329. See supra notes $45-105$ and accompanying text.

330. 694 F.2d 1017 (5th Cir. 1983). 
tronic equipment, charging that they conspiratorially refused to deal with plaintiff. A month after the complaint was filed, the trial court sua sponte stayed all discovery pending a status conference in order to "protect the plaintiff from a barrage of paper work." 331 The stay remained in effect, subject to the right to request specified discovery. ${ }^{332}$ After the trial court twice ordered plaintiff to amend its complaint to set forth specific and detailed allegations as to each defendant, defendants filed motions for summary judgment supported by affidavits denying conspiratorial activity and specifying other reasons such as lack of creditworthiness for refusing to deal with plaintiff. Plaintiff responded with an affidavit seeking discovery pursuant to Rule 56(f), eventually identifying fifteen individuals it wanted to depose, and specifying certain subjects it wished to cover in interrogatories. Emphasizing plaintiff's admission that it filed suit with limited evidence, ${ }^{393}$ the trial court found Rule 56(f) inapplicable because that Rule "is designed to enable a party to seek particular facts relevant to an already-established factual pattern of alleged antitrust activity." 334 Since plaintiff could not assure the court that the proposed discovery would produce evidence suffcient to oppose defendants' motions, the court refused to allow it to conduct a "fishing expedition," 335 and granted defendants' motions.

While troubled by indications that plaintiff's counsel had not undertaken discovery because he had been busy responding to defendants' motions, ${ }^{336}$ the Fifth Circuit affirmed. It commended the trial court's efforts to keep discovery under control, 337 pointing out that "the expensive and time consuming nature of antitrust litigation along with the statutory treble damage remedy, may particularly inspire vexatious litigation, an evil which summary judgment may guard against."338 Noting that plaintiff failed to submit affidavits on matters within its control, such as creditworthiness, and that its discovery requests "remained vague and peripheral to the key issue of conspiracy,"339 the appellate court found persuasive the views of the Second Circuit that " $[w]$ here a plaintiff fails to produce any specific facts whatsoever to support a conspiracy allegation, a district court may, in its

331. See Paul Kadair, Inc. v. Sony Corp., 88 F.R.D. 280, 284 (M.D. La. 1980), afTd, 694 F.2d 1017 (5th Cir. 1983).

332. The appellate court stated that the stay was not unequivocal about allowing discovery. See 694 F.2d at 1031. But it appears that defendants' motions were filed before the earliest time when the district court's stay order contemplated allowing any discovery. See id.

333. 88 F.R.D. at $284,285$.

334. Id. at 289.

335. Id. The court explained that "the purpose of discovery . . . would be to ascertain whatever information possible in order to set forth specific violations of the Act." 336. See 694 F.2d at 1023 n.12.

337. Id. at 1024 n. 18 .

338. Id. at 1031 .

339. Id. at 1032 . 
discretion, refuse to permit discovery and grant summary judgment." 340 Under the peculiar facts of Kadair, the court's refusal to permit plaintiff any discovery may have been justified because the likelihood that plaintiff would turn up evidence of wrongdoing was so slight. In general, however, the idea that plaintiffs should be required to make an evidentiary showing to justify access to discovery raises most of the same problems as using pleadings practice to challenge plaintiff's factual conclusions. ${ }^{341}$

Precise or general rules for Rule 56(f) decisions cannot be fashioned; ultimately, courts will have to make sensible decisions on a caseby-case basis. In evaluating the scope of discovery that will be permitted, they are likely to consider many of the factors that have already been rejected as justifications for heightened pleading standards. They are also likely to encounter difficult problems in determining whether a certain amount of discovery is enough. But confronting these difficulties is better, in an imperfect world, than pretending that the same issues can be resolved at the pleading stage. Some evidence is better than none, and discretionary control of discovery (explicitly authorized by the Rules) ${ }^{342}$ is much less unsettling than discretion to dismiss. So long as the basic focus is on whether the court can confidently conclude that the defendant did not in fact violate the plaintiff's rights, sensible judges should reach sensible results.

\section{CONCLUSION}

I fear that every age must learn its lesson that special pleading cannot be made to do the service of trial and that live issues between active litigants are not to be disposed of or evaded on the paper pleadings ....

Charles E. Clark ${ }^{343}$

This Article began by asking whether Clark's pessimism based on

340. Id. at 1030 (quoting Contemporary Mission, Inc. v. United States Postal Serv., 648 F.2d 97, 107 (2d Cir. 1981)).

341 . For a discussion of those problems, see supra notes 209-27 and accompanying text. Where, after reasonable discovery, the plaintiff cannot persuasively challenge the defendant's assertions, a court may comfortably decide against the plaintiff. See, e.g., Sames v. Gable, 732 F.2d 49 (3d Cir. 1984) (upholding summary judgment against claims that plaintiffs were demoted for political reasons on basis of defendant's denials of any such motivations in their depositions, in light of plaintiffs' failure to proffer any other evidence).

Lest Kadair be thought unique, see Wallace v. Brownell Pontiac-GMC Co., 703 F.2d 525 (11 th Cir. 1983) (defendants granted summary judgment before plaintiff had opportunity for discovery); Willmar Poultry Co. v. Morton-Norwich Prods., Inc., 520 F.2d 289 (8th Cir. 1975) (same), cert. denied, 424 U.S. 915 (1976). But cf. Sonenshein, supra note 299 , at 785 (summary judgment inappropriate when party opposing motion has not had opportunity to complete discovery).

342. Note that the wording of Rule 56(f) is discretionary, see supra note 310 . See also supra note 62 and accompanying text.

343. Clark, supra note 71 , at 46. 
Gresham's Law has been vindicated by the judicial handling of his pleading reforms. Certainly Rule $8(a)(2)$ has not received the brutal treatment the New York judges inflicted on the Field Code. ${ }^{344}$ Furthermore, Conley $v$. Gibson effectively scotched any serious efforts to revert to code pleading formalism. It is equally clear, however, that the new fact pleading is more restrictive than Clark would have wanted. The courts' efforts to puncture factual conclusions are inconsistent with the spirit of the Rules, and the present handling of legal conclusions would probably offend a reformer who originally wanted to do away with pleading motions altogether. ${ }^{345}$ So Gresham's Law seems at least partly at work, but the courts are not the only ones who have been its instruments. Clark probably would have opposed some of the 1980 and 1983 amendments to the Federal Rules of Civil Procedure; ${ }^{346}$ whether as a result of Gresham's Law or other developments, time seems to have tarnished his vision of the litigation system.

The obvious stimulus for the new fact pleading is the litigation boom, and the fact pleading cases are therefore concentrated in the areas that have experienced the greatest growth. The prospect that liberal pleading affords broad discovery to abusive litigants or lawyers is undeniably distressing. But the circumstances do not actually seem so urgent as portrayed by many. Rapid growth in the level of civil litigation is not unknown in English and American experience. ${ }^{347}$ Although the public perception of the problem has been concentrated in the last decade or two, judicial lobbying about protracted litigation goes back nearly four decades. ${ }^{348}$ Moreover, the frequency of abusive practices by plaintiffs has not been shown to be high. ${ }^{349}$ Indeed, some have gone so far as to label the current preoccupation with the litigation boom "an item of elite folklore." 350 Under these circumstances, there seems to be little reason for radical retrenching on the handling of pleadings, even if that were a promising solution.

The real question is whether pleading practice can yield reliable merits decisions. The prevalence of notice pleading jargon has obscured this question by forcing courts interested in disposing of cases on the merits to couch their decisions in terms of demanding notice of the basis of the claim. The pressures of the litigation boom could have the desirable effect of ending this camouflage effort. This Article has therefore suggested that the notice pleading rationale be abandoned. Unless there is some prospect that it will lead to a merits decision of

344. See supra note 29 and accompanying text.

345. See supra note 34 and accompanying text.

346. Cf. F. James \& G. Hazard, supra note 11 , § 3.11 , at 154-55 (characterizing requirement under amended Rule 11 of statement of factual grounds for a claim as "a move in the direction of code pleading").

347. See supra note 46 and accompanying text.

348. See supra notes 47-48 and accompanying text.

349. Cf. supra note 140 and accompanying text (relating to class actions).

350. Galanter, supra note 46 , at 64 . 
some or all of the claims or defenses, pleading practice is little better than an expensive waste of time. ${ }^{351}$

Once the notice pleading chimera is banished, very difficult problems remain. Under the Federal Rules, there is a systemic tendency to react to the risk of inaccurate decisions by adding procedural layers intended to improve accuracy. Laudable in theory, this tendency can deprive litigants of any decision on the merits; ${ }^{352}$ failure to dismiss a weak case or grant summary judgment may be something of a default in the judicial function. Sometimes a decision, even with some risk of error, may be preferable to the drain of continued litigation. If the litigation boom causes the courts to come to grips with this responsibility, that is also desirable.

The circumstances in which such merits decisions are possible on the pleadings, however, are distressingly limited. This Article has found that such situations fall generally into two categories, those in which more detail will reveal a fatal defect and those in which sufficient detail will show that the defendant has not violated the plaintiff's rights. ${ }^{353}$ As the recent experience under RICO demonstrates, ${ }^{354}$ it is often difficult to identify elements of a claim that plaintiffs should be forced to establish. Even more troubling is the risk that courts will indulge in weighing of evidence in the process of trying to decide on the basis of the pleadings whether the defendant's conduct violated the plaintiff's rights. Outside these limited areas, more stringent pleading practices cannot be justified as appropriate for "suspicious" cases ${ }^{355}$ or as part of the trial court's discretion in handling litigation. ${ }^{356}$

Instead, more flexible use of summary judgment, in tandem with case management, seems the more promising course. ${ }^{357}$ This approach reduces the disquieting possibility that a plaintiff will be unable to satisfy the court's demand for proof of the defendant's misconduct because he has been denied discovery. It is also comforting to have merits decisions based on evidence rather than allegations. Moreover, selective cost-shifting, coupled with active case management, should di-

351. See supra notes 113-21 and accompanying text.

352. Justice Rehnquist, for example, has remarked on the effect of the "seeming compulsion to make sure that the final result reached in any case is the correct one." Relınquist, Speech at University of Florida Law School (Sept. 15, 1984) at 16 (unpublished) (on file at the offices of the Columbia Law Review). This compulsion has had an effect on the design of the litigation system: "It is very much as if the government were to announce a governmental monopoly on the production of cars, and then proceed to produce only Cadillac limousines with jump seats." Id. at 14; see also Leubsdorf, Constitutional Civil Procedure, 63 Tex. L. Rev. 579, 589 (1984) ("Those who are not rich often cannot afford litigation on the scale for which the system is designed.").

353. See supra notes $149-95$ and accompanying text.

354. See supra notes $154-71$ and accompanying text.

355. See supra notes 228-77 and accompanying text.

356. See supra notes $278-96$ and accompanying text.

357. See supra notes $297-342$ and accompanying text. 
minish some concerns about litigation abuse. ${ }^{358}$ This course is neither easy nor foolproof, however. Case management is time-consuming and vexing, and Rule 56(f) requests for postponements will often require particularly difficult determinations about the utility of further discovery. Evaluating evidence in the summary judgment context is not easy, but it should be more reliable than scrutinizing factual conclusions in the pleadings. Thus, the suggestion is simply a better course, not a panacea.

In the end, Clark's pessimism seems to reflect the cyclical nature of procedural reform. For more than a century reform efforts in England and America have followed a similar course, with simplifications breeding new complexities. ${ }^{359}$ To a large extent, these difficulties result from shifting uncertainties about substantive law. They also result from the fact that we have an adversarial system in which litigants and lawyers try to use the procedures that exist to the advantage of their clients. In the face of these pressures, the reality is that manipulation of procedural mechanisms for settlement leverage will never be eliminated. ${ }^{360}$ As tinkerers, we will have to repeat the cycle of revision and relapse again and again.

358. See supra notes 66,143 and accompanying text.

359. The English Judicature Acts of 1875 represented a watershed similar to the adoption of the Federal Rules. Like the Federal Rules, the Act was designed to simplify litigation, shelve formalism, expand discovery, and assure decisions on the merits. Within 10 years, excessive litigation, particularly excessive discovery, had run up the cost of litigation so much that it was said the reforms seemed to be defeating their own ends. See Rosenbaum, Studies in English Procedure, 63 U. Pa. L. Rev. 273, 289-9 (1915). Among the remedies proposed for this situation were elimination of pleadings, id. at 295, 382, and requiring closer supervision of discovery by masters, id. at 386 .

360. Cf. Weinstein, Some Reflections on the "Abusiveness" of Class Actions, 58 F.R.D. 299, 302 (1973) ("As in any litigation, the pressure on the defendant to buy his peace through settlement cannot be totally eliminated."). 